\title{
INFLUÊNCIA DE NITROGÊNIO, ZINCO EBORO E DE SUAS RESPECTIVAS INTERAÇÕES NO DESEMPENHO DA CULTURA DE MILHO (Zea mays L.)
}

\section{MARCIO AUGUSTO SOARES}

\author{
Dissertação apresentada à Escola Superior de \\ Agricultura "Luiz de Queiroz", Universidade de São \\ Paulo, para a obtenção do título de Mestre em \\ Agronomia, Área de Concentração: Fitotecnia.
}

P I R A C I C A B A

Estado de São Paulo - Brasil

Julho - 2003 


\title{
INFLUÊNCIA DE NITROGÊNIO, ZINCO E BORO E DE SUAS RESPECTIVAS INTERAÇÕES NO DESEMPENHO DA CULTURA DE MILHO (Zea mays L.)
}

\section{MARCIO AUGUSTO SOARES}

Engenheiro Agrônomo

\author{
Orientador: Prof. Dr. DURVAL DOURADO NETO
}

\begin{abstract}
Dissertação apresentada à Escola Superior de Agricultura "Luiz de Queiroz", Universidade de São Paulo, para a obtenção do título de Mestre em Agronomia, Área de Concentração: Fitotecnia.
\end{abstract}

P I R A C I C A B A

Estado de São Paulo - Brasil

Julho - 2003 
Dados Internacionais de Catalogação na Publicação (CIP)

DIVISÃO DE BIBLIOTECA E DOCUMENTAÇÃO - ESALQ/USP

\section{Soares, Marcio Augusto}

Influência de nitrogênio, zinco e boro e de suas respectivas interações no

desempenho da cultura de milho (Zea Mays L. ) / Marcio Augusto Soares. - -

Piracicaba, 2003.

$92 \mathrm{p}$.

Dissertação (mestrado) - - Escola Superior de Agricultura "Luiz de Queiroz", 2003.

Bibliografia.

1. Adubação 2. Boro 3. Fenologia 4. Fisiologia vegetal 5. Índice de área foliar 6. Milho 7. Nitrogênio 8. Znco I. Título

CDD 633.15

'Permitida a cópia total ou parcial deste documento, desde que citada a fonte - $\mathrm{O}$ autor" 
Em especial DEDICO,

à minha esposa Isabela, pela compreensão

nas minhas ausências, pelo companheirismo

e pelo incentivo à realização deste trabalho.

\section{OFEREÇO,}

aos meus pais, Walter e Helena, pelo apoio e pelo carinho oferecido em todas as fases da minha vida.

às minhas irmãs, Helenice e Silvana, pelo incentivo.

ao meu orientador, Prof. Durval, pela oportunidade, pela dedicação e pelos valiosos ensinamentos.

ao Prof. Fancelli pelo auxílio na idealização do projeto, pelo incentivo e pela valiosa dedicação e atenção dispensada. 


\section{AGRADECIMENTOS}

Ao Professor Dr. Durval Dourado Neto, pelo incentivo, pelo companheirismo e pela excelente orientação em todas as fases do projeto.

Ao Professor Dr. Antônio Luiz Fancelli, pelo constante apoio e pelos valiosos ensinamentos.

Ao Professor Dr. José Laércio Favarin, pelas orientações durante a condução do projeto e pelo grande companheirismo.

Ao Professor Dr. José Dias da Costa, pela colaboração.

À Eng. Agr. Aline de Holanda Nunes Maia, pela valiosa orientação e auxílio na análise estatística.

Aos funcionários e colegas do Departamento de Produção Vegetal (ESALQ/USP), em especial aos senhores Edson Teramoto e Jair Vitório Arthur, pela inestimável colaboração na condução deste trabalho.

À Guacho Agropecuária S/A, em especial aos engenheiros agrônomos João Guilherme Domingues Iglesias e Aprígio Tank Júnior pela compreensão e pelo apoio oferecido principalmente na fase final do projeto.

Ao colega Ramiro Fernando Lopes Ovejero pela amizade e valiosa colaboração na condução do trabalho.

À bibliotecária Eliana Maria Garcia, pela revisão do item Referências Bibliográficas e da formatação geral do texto.

A todos aqueles que, embora não mencionados, sabem que contribuíram em alguma etapa da minha vida. 


\section{SUMÁRIO}

Página

LISTA DE FIGURAS

viii

LISTA DE TABELAS

$\mathrm{X}$

LISTA DE SÍMBOLOS

xiv

RESUMO

xvi

SUMMARY

xviii

1 INTRODUÇÃO 1

2 REVISÃO DE LITERATURA 4

2.1 Importância da cultura 4

2.2 Fenologia 5

$\begin{array}{lll}2.3 & \text { Ecofisiologia e produtividade da cultura } & 7\end{array}$

2.4 Importância dos nutrientes estudados para a cultura de milho 9

2.4.1 Nitrogênio 11

2.4.2 Zinco 13

$\begin{array}{lll}2.4 .3 & \text { Boro } & 17\end{array}$

3 MATERIAL E MÉTODOS 22

3.1 Local do experimento 22

3.2 Caracterização física e química do solo 22

$\begin{array}{lll}3.3 & \text { Informações meteorológicas } & 22\end{array}$

3.4 Implantação e condução do experimento de campo 24

3.4.1 Semeadura e tratos culturais 24

3.4.2 Nutrientes avaliados, tratamentos e metodologia de aplicação 25

$\begin{array}{lll}3.5 & \text { Avaliações fitotécnicas } & 27\end{array}$

$\begin{array}{lll}\text { 3.5.1 Fenologia } & 27\end{array}$ 
3.5.2 Área foliar e índice de área foliar 27

3.5.3 Altura média da base do pendão e altura média de inserção de espiga 28

3.5.4 Diâmetro médio do colmo 28

3.5.5 Comprimento médio do primeiro e do segundo internódio do colmo 28

3.5.6 Massa média de matéria seca de folha, colmo, pendão e espiga 29

3.5.7 Componentes de produtividade 29

3.5.7.1 Prolificidade 29

3.5.7.2 Comprimento médio da espiga 29

3.5.7.3 Número médio de grãos por fileira da espiga 29

3.5.7.4 Numero médio de fileiras de grãos da espiga 30

3.5.7.5 Diâmetro médio da espiga 30

3.5.7.6 Diâmetro médio do sabugo 30

3.5.7.7 Comprimento médio de grãos 30

3.5.7.8 Massa de mil grãos $\quad 30$

3.5.8 Produtividade 31

3.6 Delineamento experimental 31

4 RESULTADOS E DISCUSSÃO 32

4.1 Síntese dos resultados 32

4.1.1 Valores médios referentes às variáveis estudadas 34

4.1.2 Resultados das análises de varî̀ncia 39

4.1.3 Análise de correlação linear 43

$\begin{array}{lll}\text { 4.1.4 Relação entre as variáveis estudadas } & 47\end{array}$

4.2 Avaliações fitotécnicas 51

4.2.1 Número de folhas por planta e índice de área foliar 51

4.2.2 Altura média da base do pendão e altura média de inserção de espiga 60

4.2.3 Diâmetro médio do colmo 62

4.2.4 Comprimento médio do primeiro e do segundo internódio do colmo 64

4.2.5 Massa média de matéria seca de folha, colmo, pendão e espiga 66 
4.2.6 Componentes de produção $\quad 69$

$\begin{array}{lll}\text { 4.2.6.1 Prolificidade } & 69\end{array}$

$\begin{array}{ll}\text { 4.2.6.2 Comprimento médio da espiga } & 70\end{array}$

4.2.6.3 Número médio de grãos por fileira da espiga 72

4.2.6.4 Numero médio de fileiras de grãos da espiga 75

4.2.6.5 Comprimento médio dos grãos 75

$\begin{array}{lll}\text { 4.2.6.6 } & \text { Massa de mil grãos } & 75\end{array}$

$\begin{array}{lll}\text { 4.2.7 Produtividade } & 78\end{array}$

5 CONCLUSÕES 83

REFERÊNCIAS BIBLIOGRÁFICAS 


\section{LISTA DE FIGURAS}

Página

1 Número de folhas fotossinteticamente ativas por planta (NF2), determinado aos 41 dias após a emergência, em função da aplicação de doses de nitrogênio (DN, kg.ha $\left.{ }^{-1}\right)$

2 Índice de área foliar (IAF2), determinado aos 41 dias após a emergência das plantas de milho, em função da aplicação de doses crescentes de boro (DB, kg.ha $\left.{ }^{-1}\right)$, para as três diferentes doses de $\mathrm{N}\left(\mathrm{DN}, \mathrm{kg} \cdot \mathrm{ha}^{-1}\right)$

3 Número de folhas fotossinteticamente ativas por planta (NF3), determinado aos 49 dias após a emergência, em função da aplicação de doses de nitrogênio (DN, kg.ha-1)

4 Índice de área foliar médio (IAF3, $\mathrm{m}^{2} \cdot \mathrm{m}^{-2}$ ), determinado aos 49 dias após a emergência, em função da aplicação de doses de nitrogênio (DN, kg.ha ${ }^{-1}$ )

5 Índice de área foliar médio no florescimento (IAF4, $\mathrm{m}^{2} . \mathrm{m}^{-2}$ ), determinado aos 65 dias após a emergência, em função da aplicação de doses de nitrogênio (DN, kg.ha-1)

6 Número de folhas fotossinteticamente ativas por planta (NF4), determinado aos 65 dias após a emergência das plantas de milho (florescimento), em função da aplicação de doses crescentes de zinco (DZn, kg.ha ${ }^{-1}$ ), para as três diferentes doses de $\mathrm{N}\left(\mathrm{DN}, \mathrm{kg} \cdot \mathrm{ha}^{-1}\right)$

7 Altura média da base do pendão (ABP, m) das plantas de milho em função de doses de nitrogênio (DN, $\left.\mathrm{kg}_{\mathrm{h}} \mathrm{ha}^{-1}\right)$

8 Altura média da inserção de espiga (AIE, m) das plantas de milho em função de doses de nitrogênio (DN, kg.ha ${ }^{-1}$ ) 
9 Diâmetro do colmo de planta de milho (DC, $\mathrm{cm}$ ) em função de doses de nitrogênio (DN, kg.ha ${ }^{-1}$ )

10 Comprimento médio do segundo internódio do colmo (COMP_NO2, cm) em função da aplicação de doses de nitrogênio (DN, kg.ha ${ }^{-1}$ )

11 Massa de matéria seca de colmo (MMSC, g.planta ${ }^{-1}$ ), em função da aplicação de doses de nitrogênio (DN, kg.ha ${ }^{-1}$ ) e de zinco (DZn, kg.ha ${ }^{-1}$ )

12 Massa de matéria seca de folha (MMSF, g.planta ${ }^{-1}$ ), em função da aplicação de doses de nitrogênio (DN, kg.ha ${ }^{-1}$ ) e de zinco (DZn, kg.ha ${ }^{-1}$ )

13 Massa de matéria seca de espiga (MMSE, g.planta ${ }^{-1}$ ) em função da aplicação de doses de nitrogênio (DN, kg.ha ${ }^{-1}$ )

14 Prolificidade (PROLIF) das plantas de milho em função de doses de nitrogênio (DN, kg.ha $\left.{ }^{-1}\right)$

15 Comprimento médio de espigas de milho (COMPESP, cm) em função de doses de nitrogênio (DN, ${\mathrm{kg} . \mathrm{ha}^{-1}}^{\text {) }}$

16 Número médio de grãos por fileira (NGF), em função da aplicação de doses crescentes de B e de N. $\left(\mathrm{kg}_{\mathrm{h}} \mathrm{ha}^{-1}\right)$

17 Massa de mil grãos (M1000G, g) em função da aplicação de doses crescentes de zinco (DZn, kg.ha ${ }^{-1}$ ), para as três diferentes doses de $\mathrm{N}\left(\mathrm{DN}, \mathrm{kg}_{\mathrm{h}} \mathrm{ha}^{-1}\right.$ )

18 Produtividade da cultura de milho (PROD, kg.ha ${ }^{-1}$ ) em função de doses de nitrogênio (DN, kg.ha ${ }^{-1}$ ) 


\section{LISTA DE TABELAS}

Página

1 Descrição sucinta dos estádios fenológicos da cultura de milho (Fancelli, 1986 e Fancelli \& Dourado Neto, 1997)

2 Resultado da análise química de solo da área experimental

3 Valores de radiação global média $\left(\mathrm{RGM}, \mathrm{cal} \mathrm{cm}^{-2} \cdot \mathrm{dia}^{-1}\right)$, precipitação total (P, mm), umidade relativa média (UR, \%) do ar (determinada às 7:00h), temperatura $\left({ }^{\circ} \mathrm{C}\right)$ do ar (temperaturas máxima, mínima e média), e evaporação total do tanque classe $\mathrm{A}(\mathrm{E}, \mathrm{mm})$ por decêndios, registrados durante o período de condução do experimento

4 Descrição sucinta dos tratamentos estudados

5 Valores médios de número de folhas fotossinteticamente ativas por planta aos 20 (NF1), 41 (NF2), 49 (NF3) e 65 (NF4) dias após a emergência em função das doses $\left(\mathrm{kg}_{\mathrm{h}} \mathrm{ha}^{-1}\right)$ de nitrogênio (DN), zinco (DZn) e boro (DB)

6 Valores médios de índice de área foliar $\left(\mathrm{m}^{2} \cdot \mathrm{m}^{-2}\right)$ aos 20 (IAF1), 41 (IAF2), 49 (IAF3) e 65 (IAF4) dias após a emergência em função das doses $\left(\mathrm{kg}_{\text {.ha }}{ }^{-1}\right)$ de nitrogênio (DN), zinco (DZn) e boro (DB)

7 Valores médios de diâmetro do colmo (DC, $\mathrm{cm}$ ), massa de matéria seca de folha (MMSF, g.planta ${ }^{-1}$ ), colmo (MMSC, g.planta ${ }^{-1}$ ), espiga com palha $\left(\right.$ MMSE, g.espiga $^{-1}$ ) e pendão (MMSP, g.planta ${ }^{-1}$ ), em função das doses $\left(\mathrm{kg} \mathrm{ha}^{-1}\right)$ de nitrogênio (DN), zinco (DZn) e boro (DB) 
8 Valores médios de altura da base de pendão (ABP, $\mathrm{m}$ ), altura de inserção de espiga (AIE, m), prolificidade (PROLIF, espiga.planta ${ }^{-1}$ ), comprimento do primeiro (COMP_NO1, cm) e segundo (COMP_NO2, cm) internódios em função das doses $\left(\mathrm{kg} \cdot \mathrm{ha}^{-1}\right)$ de nitrogênio (DN), zinco (DZn) e boro (DB)

9 Valores médios de número de fileiras de grãos por espiga (NFG), número de grãos por fileira (NGF), comprimento do grão (COMPGRAO, $\mathrm{cm}$ ) e da espiga (COMPESP, cm), massa de mil grãos (M1000G, g) e produtividade (PROD, kg.ha $\left.{ }^{-1}\right)$ em função das doses $\left(\mathrm{kg} \cdot \mathrm{ha}^{-1}\right)$ de nitrogênio (DN), zinco (DZn) e boro (DB)

10 Resultado dos testes $\mathrm{F}$ para avaliar o efeito das doses de nitrogênio $\left(\mathrm{DN}, \mathrm{kg} \cdot \mathrm{ha}^{-1}\right)$, boro (DB, kg.ha $\left.{ }^{-1}\right)$ e zinco $\left(\mathrm{DZn}, \mathrm{kg} \mathrm{ha}^{-1}\right)$ e suas interações, sobre variáveis altura de inserção de espiga (AIE), comprimento do primeiro (COMP_NO1) e do segundo (COMP_NO2) internódios, comprimento da espiga (COMPESP) e do grão (COMPGRAO)

11 Resultado dos testes $\mathrm{F}$ para avaliar o efeito das doses de nitrogênio $\left(\mathrm{DN}, \mathrm{kg} \cdot \mathrm{ha}^{-1}\right)$, boro $\left(\mathrm{DB}, \mathrm{kg} \cdot \mathrm{ha}^{-1}\right)$ e zinco $\left(\mathrm{DZn}, \mathrm{kg} \mathrm{ha}^{-1}\right)$ e suas interações, sobre variáveis altura da base de pendão (ABP), índice de área foliar determinado aos 20 (IAF1), 41 (IAF2), 49 (IAF3) e 65 (IAF4) dias após a emergência e diâmetro do colmo (DC)

12 Resultado dos testes $\mathrm{F}$ para avaliar o efeito das doses de nitrogênio $\left(\mathrm{DN}, \mathrm{kg} \cdot \mathrm{ha}^{-1}\right)$, boro (DB, kg.ha $\left.{ }^{-1}\right)$ e zinco (DZn, kg.ha- $\left.{ }^{-1}\right)$ e suas interações, sobre variáveis número de fileiras de grãos por espiga (NFG), número de folhas fotossinteticamente ativas determinado aos 41 (NF2), 49 (NF3) e 65 (NF4) DAE, número de grãos por fileira (NGF) e prolificidade (PROLIF)

13 Resultado dos testes $\mathrm{F}$ para avaliar o efeito das doses de nitrogênio $\left(\mathrm{DN}, \mathrm{kg} \cdot \mathrm{ha}^{-1}\right)$, boro (DB, kg.ha $\left.{ }^{-1}\right)$ e zinco $\left(\mathrm{DZn}, \mathrm{kg} \cdot \mathrm{ha}^{-1}\right)$ e suas interações, sobre variáveis massa de mil grãos (M1000G), produtividade (PROD), massa de matéria seca de colmo (MMSC), folha (MMSF), pendão (MMSP) e espiga (MMSE) 
14 Coeficiente de correlação de Pearson $(n=81)$ entre as variáveis analisadas e nível de significância (entre parêntesis) associado ao teste $t$

15 Coeficiente de correlação de Pearson $(n=81)$ entre as variáveis analisadas e nível de significância (entre parêntesis) associado ao teste t

16 Coeficiente de correlação de Pearson $(n=81)$ e nível de significância (entre parêntesis) entre as variáveis analisadas

17 Estimativas dos parâmetros do modelo de regressão polinomial quadrático, com os respectivos valores de erro padrão, que descrevem a relação entre as variáveis estudadas e as doses de $\mathrm{N}$ aplicadas

18 Estimativas dos parâmetros do modelo de regressão polinomial quadrático, com os respectivos valores de erro padrão, que descrevem a relação entre as variáveis estudadas e as doses de $\mathrm{N}$ aplicadas

19 Estimativas dos parâmetros do modelo de regressão polinomial quadrático, com os respectivos valores de erro padrão, que descrevem a relação entre as variáveis NGF e IAF2 e as doses de boro em cada dose de nitrogênio (DN, kg.ha ${ }^{-1}$ )

20 Estimativas dos parâmetros do modelo de regressão polinomial quadrático, com os respectivos valores de erro padrão, que descrevem a relação entre as variáveis número de folhas fotossinteticamente ativas aos 65 dias após a emergência (NF4) e massa de mil grãos (M1000G) e as doses de zinco em cada dose de nitrogênio (DN, kg.ha ${ }^{-1}$ )

21 Modelo referente à massa de matéria seca de colmo (MMSC, g.planta ${ }^{-1}$ ) em função da aplicação de doses de nitrogênio (DN, kg.há $\left.{ }^{-1}\right)$ e de zinco (DZn, kg.há ${ }^{-1}$ )

22 Análise de variância referente ao modelo de estimativa da massa de matéria seca de colmo (MMSC, g. planta $^{-1}$ ), em função da aplicação de doses de nitrogênio (DN, kg.há $\left.{ }^{-1}\right)$ e de zinco (DZn, kg.há $\left.{ }^{-1}\right)$ 
23 Modelo referente à massa de matéria seca de folha (MMSC, g. planta ${ }^{-1}$ ), em função da aplicação de doses de nitrogênio (DN, kg.há ${ }^{-1}$ ) e de zinco (DZn, kg.há-1)

24 Análise de variância referente ao modelo de estimativa da massa de matéria seca de folha (MMSC, g. planta ${ }^{-1}$ ), em função da aplicação de doses de nitrogênio (DN, kg.há $\left.{ }^{-1}\right)$ e de zinco (DZn, kg.há $\left.{ }^{-1}\right)$ 


\section{LISTA DE SÍMBOLOS}

ABP $\quad$ Altura da base de pendão $(\mathrm{cm})$

AIE Altura de inserção de espiga $(\mathrm{cm})$

B Boro

COMP_NO1 Comprimento do primeiro internódio $(\mathrm{cm})$

COMP_NO2 Comprimento do segundo internódio (cm)

COMPESP Comprimento da espiga $(\mathrm{cm})$

COMPGRAO Comprimento do grão $(\mathrm{cm})$

DAE Dias após a emergência

DB Dose de boro $\left(\mathrm{kg} \cdot \mathrm{ha}^{-1}\right)$

DC Diâmetro do colmo $(\mathrm{cm})$

DE Diâmetro da espiga $(\mathrm{cm})$

DN Dose de nitrogênio $\left(\mathrm{kg}_{\mathrm{h}} \mathrm{ha}^{-1}\right)$

DS Diâmetro do sabugo $(\mathrm{cm})$

DZn Dose de zinco $\left(\mathrm{kg}_{\mathrm{h}} \mathrm{ha}^{-1}\right)$

E Evaporação total (mm)

F Valor F - relação entre o quadrado médio do fator estudado (N, B, Zn e interações, neste trabalho) e o quadrado médio do resíduo

GL Graus de liberdade

IAF1 Índice de área foliar aos 20 dias após a emergência das plantas $\left(\mathrm{m}^{2} \cdot \mathrm{m}^{-2}\right)$

IAF2 Índice de área foliar aos 41 dias após a emergência das plantas $\left(\mathrm{m}^{2} \cdot \mathrm{m}^{-2}\right)$

IAF3 Índice de área foliar aos 49 dias após a emergência das plantas $\left(\mathrm{m}^{2} \cdot \mathrm{m}^{-2}\right)$

IAF4 Índice de área foliar aos 65 dias após a emergência das plantas $\left(\mathrm{m}^{2} \cdot \mathrm{m}^{-2}\right)$

M1000G Massa de mil grãos (g) 
MMSC Massa de matéria seca de colmo (g.planta ${ }^{-1}$ )

MMSE Massa de matéria seca de espiga $\left(\right.$ g.espiga $^{-1}$ )

MMSF Massa de matéria seca de folha (g.planta ${ }^{-1}$ )

MMSP Massa de matéria seca de pendão (g.planta ${ }^{-1}$ )

$\mathrm{N} \quad$ Nitrogênio

NF1 Número de folhas fotossinteticamente ativas aos 20 DAE

NF2 Número de folhas fotossinteticamente ativas aos 41 DAE

NF3 Número de folhas fotossinteticamente ativas aos 49 DAE

NF4 Número de folhas fotossinteticamente ativas aos 65 DAE

NFG Número de fileiras de grãos por espiga (fileira.espiga ${ }^{-1}$ )

NGF Número de grãos por fileira (grão.fileira ${ }^{-1}$ )

P Precipitação total (mm)

PROB Probabilidade de a estatística F ser superior ao valor F observado no experimento sob a hipótese de ausência de efeito de tratamento (probabilidade do erro tipo I)

PROD Produtividade $\left({\left.\mathrm{kg} . h a^{-1}\right)}^{-1}\right.$

PROLIF Prolificidade (espiga.planta ${ }^{-1}$ )

RGM Radiação global média $\left(\mathrm{cal}^{\mathrm{cm}} \mathrm{cm}^{-2} \cdot \operatorname{dia}^{-1}\right)$

UR Umidade relativa do ar (\%)

Zn Zinco 


\section{INFLUÊNCIA DE NITROGÊNIO, ZINCO EBORO E DE SUAS RESPECTIVAS INTERAÇÕES NO DESEMPENHO DA CULTURA DE MILHO (Zea mays L.)}

Autor: MARCIO AUGUSTO SOARES

Orientador: Prof. Dr. DURVAL DOURADO NETO

\section{RESUMO}

O presente trabalho teve como objetivo avaliar o modo como os micronutrientes zinco e boro e suas interações com a adubação nitrogenada influenciam no desempenho da cultura do milho (Zea mays L.). O experimento foi conduzido em área pertencente à Escola Superior de Agricultura "Luiz de Queiroz" (ESALQ/USP), no município de Piracicaba-SP, no ano agrícola de 2000/2001, em solo classificado como Nitossolo Vermelho, Eutrófico, onde foi semeado o híbrido Cargill 909. O delineamento experimental utilizado foi casualizado em blocos com vinte e sete tratamentos e três repetições, onde tanto o zinco como o boro foram aplicados de forma localizada no sulco, por ocasião da semeadura do milho. Os tratamentos corresponderam a cinco doses de zinco $\left(0,2,4\right.$, 8 e 16 kg.ha $\left.{ }^{-1}\right)$ e cinco doses de boro (0, 1, 2, 4 e $\left.8 \mathrm{~kg}^{-h^{-1}}\right)$, associados ou não ao nitrogênio, o qual foi aplicado em três doses $\left(0,120\right.$ e $\left.240 \mathrm{~kg}^{\circ} \mathrm{ha}^{-1}\right)$. Cabe salientar que o nitrogênio foi aplicado parceladamente na forma de uréia $(45 \% \mathrm{~N})$, sendo 30 kg.ha ${ }^{-1}$ aplicados no sulco de semeadura e o complemento, específico de cada tratamento, em cobertura, no momento em que a cultura de milho apresentava cinco folhas plenamente expandidas. Como fontes de zinco e de boro, foram utilizados o sulfato de zinco $(20 \%$ Zn) e o ácido bórico $(17 \%$ B), respectivamente. Todas as parcelas receberam, no sulco de semeadura, $80 \mathrm{~kg}^{-h^{-1}}$ de $\mathrm{P}_{2} \mathrm{O}_{5}$, na forma de superfosfato simples, e $60 \mathrm{~kg} \mathrm{ha}^{-1}$ de $\mathrm{K}_{2} \mathrm{O}$, na forma de cloreto de potássio. Visando avaliar especificamente a influência dos referidos nutrientes nas plantas de milho, as parcelas 
experimentais foram mantidas totalmente livre da presença de pragas, doenças e plantas daninhas durante todo o ciclo da cultura. Quanto às avaliações, foram determinados o índice de área foliar, o número de folhas fotossinteticamente ativas por planta, a altura de planta, a altura de inserção da espiga, o diâmetro do colmo, o comprimento do primeiro e do segundo internódio do colmo e a massa de matéria seca de folhas, colmo, pendão e espiga. Ainda, foram determinados os componentes de produção como o número de espigas por planta (prolificidade), o comprimento da espiga, o número de grãos por fileira, o número de fileiras de grãos na espiga, o comprimento dos grãos, a massa de mil grãos e a produtividade de grãos. De acordo com os resultados obtidos, concluiu-se que a aplicação de nitrogênio em doses crescentes proporcionou aumento tanto da produtividade de grãos, como de uma série de outras variáveis que contribuíram para esse aumento. As variáveis numero de folhas e índices de área foliar aos 20 dias após a emergência, comprimento do primeiro internódio do colmo, massa de matéria seca de pendão, numero de fileiras de grãos e o comprimento dos grãos não apresentaram respostas a nenhum dos nutrientes estudados. A máxima produtividade de grãos (9182 $\mathrm{kg} \cdot \mathrm{ha}^{-1}$ ) foi obtida mediante o uso da maior dose de $\mathrm{N}$, sendo essa dose considerada não recomendada devido ao baixo incremento que proporcionou (9\%) em relação à aplicação de $120 \mathrm{~kg} \cdot \mathrm{ha}^{-1}$ de $\mathrm{N}$. Doses de $\mathrm{N}$ maiores que $120 \mathrm{~kg} \cdot \mathrm{ha}^{-1}$ não proporcionaram aumento satisfatórios das variáveis estudadas, inclusive da produtividade. Doses elevadas de zinco ( até $16 \mathrm{~kg} \mathrm{ha}^{-1}$ ) e de boro (até $8 \mathrm{~kg} \cdot \mathrm{ha}^{-1}$ ) aplicadas no sulco de semeadura não exerceram influência sobre a produtividade de grãos, permitindo concluir que, nas condições em que o trabalho foi desenvolvido, a toxidez provocada pelo excesso de micronutriente é mínimo. A variável que apresentou maior correlação com a produtividade de grãos foi o comprimento de espigas. Houve também alta correlação do numero de folhas com o índice de área foliar. 


\section{INFLUENCE OF NITROGEN, ZINC AND BORON AND THEIR INTERACTIONS IN THE MAIZE (Zea mays L.) CROP PERFORMANCE Author: MARCIO AUGUSTO SOARES Adviser: Prof. Dr. DURVAL DOURADO NETO}

\section{SUMMARY}

With the purpose of evaluating the nitrogen, zinc and boron and their interactions in the maize crop performance, a field experiment was carried out at Piracicaba, São Paulo State, Brazil (University of São Paulo, ESALQ), during the agricultural year of 2000/2001, where the Typic Kandiudalf soil and Cargill 909 hybrid were used. The experimental design was completely randomized blocks with twenty seven treatments and three replications, where zinc and boron were applied at maize sowing day. The treatments had five zinc doses $\left(0,2,4,8\right.$ and $\left.16 \mathrm{~kg}^{-h a^{-1}}\right)$ and five boron doses $\left(0,1,2,4\right.$ and $\left.8 \mathrm{~kg} \mathrm{ha}^{-1}\right)$, associated or not to the nitrogen, which was applied in three doses $\left(0,120\right.$ and $\left.240 \mathrm{~kg} \cdot \mathrm{ha}^{-1}\right)$. The nitrogen was applied using urea form $(45 \% \mathrm{~N})$, being $30 \mathrm{~kg} \cdot \mathrm{ha}^{-1}$ applied at sowing day and he complement, specific for each treatment, when the maize crop presented five leaves completely expanded. The zinc sulphate $(20 \% \mathrm{Zn})$ and boric acid had been used $(17 \% \mathrm{~B})$ as source of zinc and boron, respectively. All plots had received, at sowing day, $80 \mathrm{~kg} \cdot \mathrm{ha}^{-1}$ of $\mathrm{P}_{2} \mathrm{O}_{5}$, and $60 \mathrm{~kg} \cdot \mathrm{ha}^{-1}$ of $\mathrm{K}_{2} \mathrm{O}$ (potassium chloride). To evaluate the influence of the nutrient related of maize crop, the experimental area had been kept total free of weeds, pests and diseases during all crop cycle. The following evaluations were done: the maize crop phenological stages, leaf area, spike insertion and plant height, diameter of stem internode (first and second), dry mass of leaves, stem, tassel and spike, number of spikes per plant, mass of spikes with and without straw, mass of thousand grains, spike diameter, grain length, number of 
grain rows in the spike, spike length, number of grains per row and grains productivity.

Accordging to the results, it was possible to verify that the nitrogen application in crescent doses increased the grain productivity and other variables. The following variables did not present relationship with all nutrients studied: number of leaves and leaf area index at twenty days after emergency, length of first internode stem, tassel dry mass, number of grain rows and the grain length. The maximum grain productivity (9182 kg.ha ${ }^{-1}$ ) was obtained under higher dose of $\mathrm{N}$, where it was not reccomended because the yiled increment was only $9 \%$ when compared with $120 \mathrm{~kg}^{-h^{-1}}$ of $\mathrm{N}$ dose. Doses of $\mathrm{N}$ higher than $120 \mathrm{~kg} \cdot \mathrm{ha}^{-1}$ did not increase all studied variables, including grain productivity. High doses of zinc (up to $16 \mathrm{~kg} \cdot \mathrm{ha}^{-1}$ ) and boron (up to $8 \mathrm{~kg}^{-h^{-1}}$ ) applied at sowing date did not influence the grain productivity, allowing to conclude that, under field experiment condition, the toxicity produced by micronutrient excess is minimum. The spike length was the variable with higher correlation with grain productivity. There was also high correlation between number of leaves and leaf area index. 


\section{INTRODUÇÃO}

$\mathrm{O}$ fornecimento adequado de nutrientes à cultura de milho (momento correto $\mathrm{e}$ dose adequada), é, incontestavelmente, fundamental para o ótimo desenvolvimento e crescimento da cultura de milho para a obtenção de altas produtividades. Assim, o estudo contínuo desse assunto pode ser considerado fundamental para o aprimoramento de técnicas, sendo que, nesse contexto, a contribuição dos órgãos de pesquisa torna-se imprescindível, uma vez que grande parte dos produtores se mantém atentos e seguem as novas tecnologias desenvolvidas e preconizadas por tais órgãos.

Segundo Malavolta et al. (1991), apesar dos inúmeros trabalhos desenvolvidos com micronutrientes no Brasil, muitas dúvidas ainda surgem a respeito do efeito das fontes de nutrientes aplicadas, bem como das doses ideais, do modo e do local mais adequado de aplicação. Assim, muitos prejuízos ainda têm ocorrido devido à utilização incorreta de determinados nutrientes na cultura de milho, principalmente devido à utilização de doses inadequadas, o que pode resultar em danos provocados tanto por toxidez como por deficiência.

Conforme relatado por Fancelli \& Dourado Neto (2000), o aproveitamento eficiente da água e dos nutrientes pela cultura de milho depende diretamente do manejo racional do solo e da cultura, o qual reveste-se de suma importância para o crescimento e distribuição do sistema radicular. Nesse particular, a elevada concentração de nutrientes nas camadas superficiais do solo, a acentuada disponibilidade temporal de nutrientes e índices desfavoráveis de salinidade poderão afetar significativamente a arquitetura da raiz (distribuição detalhada de raízes individuais no espaço tridimensional), dificultando o aproveitamento de água e nutrientes por parte da planta.

Ferreira (1997) relata que dentre os macronutrientes essenciais para a cultura de milho, o nitrogênio é considerado um dos elementos fundamentais para a obtenção de 
aumento na produtividade, uma vez que apresenta suma importância no metabolismo das plantas, participando como constituinte de moléculas de proteínas, coenzimas, ácidos nucléicos, citocromos e de moléculas de clorofila. Assim, o estudo da sua dinâmica em sistemas agrícolas, bem como da determinação de doses consideradas ideais e que propiciem a máxima produtividade das culturas, tem despertado grande interesse devido ao aumento na demanda por alimentos, determinado pela rápida expansão da população mundial.

Entre os micronutrientes, o boro e o zinco, de acordo com Malavolta et al. (1987), são considerados extremamente importantes para a cultura de milho, sendo que a deficiência desses elementos é muito comum nos solos brasileiros, manifestando-se em grande parte das áreas ocupadas com a cultura. Cabe salientar que, apesar das incontestáveis vantagens proporcionadas pela adição de boro e zinco na adubação da cultura de milho, muitos autores citam a existência de riscos perante o uso de doses elevadas desses elementos, principalmente se concentrados no sulco de semeadura. Conforme relatado por Yamada (2000), muitos trabalhos não recomendam a aplicação de maiores doses de boro no solo, que as atualmente praticadas, por afirmarem que a faixa entre a deficiência e a fitotoxidez de boro na planta seria muito estreita. Porém, segundo Chapman et al. (1997), na literatura científica existem trabalhos que colocam em dúvida esse dogma, mostrando que não há evidência que suporte a idéia da faixa estreita entre deficiência e toxidez de boro.

Quanto à interação entre os elementos nitrogênio, boro e zinco, alguns trabalhos foram realizados no intuito de verificá-la. Ferreira (1997) destaca que o crescimento das plantas de milho, promovido pela aplicação de doses elevadas de nitrogênio, resulta na diluição de zinco na planta, provocando a deficiência do referido elemento e a necessidade de seu uso na adubação da cultura. Ferreira (1997), ao estudar a interação entre os elementos nitrogênio e zinco, através do uso de quatro doses de nitrogênio $(0$, 70, 140 e $\left.210 \mathrm{~kg} \cdot \mathrm{ha}^{-1}\right)$ e de duas doses de zinco (0 e 3,0 kg.ha $\left.{ }^{-1}\right)$ aplicado no sulco de semeadura, em que usou como fontes o sulfato de amônio e o sulfato de zinco, concluiu que a aplicação de zinco e suas interações com o nitrogênio não influenciaram nenhuma das variáveis analisadas, inclusive a produtividade de grãos. O referido autor destaca que 
observou respostas da cultura de milho (aumento no número de espigas por planta, no peso de espigas com palha, no peso de mil grãos e na produtividade de grãos) apenas às doses crescentes de nitrogênio aplicadas, sendo que a melhor representação foi alcançada pelas curvas de resposta de efeito quadrático, obtendo-se a máxima produtividade na dose de $200 \mathrm{~kg} \cdot \mathrm{ha}^{-1}$ de nitrogênio. Yamada (2000) relata que boro e zinco são essenciais para o funcionamento ótimo da ATPase e que na ausência de boro pode haver redução na eficiência de zinco na planta, e vice-versa. Lima Filho (1991) observou grande interação entre os elementos zinco e boro ao aplicá-los em plantas de cafeeiro, onde constatou que o aumento no teor de matéria seca ocorria com o aumento das doses de zinco apenas quando se elevava o teor de boro no solo.

Dentro desse contexto, é considerado de fundamental importância a avaliação, em condições de campo, da influência dos elementos zinco, boro e nitrogênio, aplicados em diferentes doses no sulco de semeadura e em cobertura, uma vez que a determinação das doses necessárias para a obtenção da máxima produtividade de grãos de milho e a verificação da existência ou não de fitotoxidez à cultura provocada por altas doses de boro e zinco, em combinação com diferentes doses de nitrogênio, poderão auxiliar sobremaneira no planejamento da adubação. Sendo assim, o presente trabalho foi realizado com o objetivo de avaliar a influência de nitrogênio, zinco e boro e de suas respectivas interações no desempenho da cultura de milho. 


\section{REVISÃO DE LITERATURA}

\subsection{Importância da cultura}

O milho é uma monocotiledônea pertencente à família das poáceas, gênero Zea, cientificamente denominado Zea mays L. (Fancelli \& Lima, 1982).

Historicamente, o milho sempre representou uma das principais culturas da agricultura brasileira, não somente no aspecto quantitativo, como também no que diz respeito à sua importância estratégica por ser a base da alimentação animal e, conseqüientemente, humana.

O milho possui a seguinte composição média: $60 \%$ de carboidratos, $10 \%$ de proteínas, 4\% de lipídios, além de minerais e vitaminas (Fancelli \& Lima, 1982). Fancelli \& Dourado Neto (2000) relatam que as proteínas presentes nos grãos de milho são albumina, globulina, prolamina e glutelina.

Essa constituição propicia que esse cereal seja utilizado no preparo de mais de 500 derivados (Nogueira Júnior et al., 1987), sendo a base de complexos industriais diversificados e, nos dias de hoje, um relevante fator sócio-econômico para muitas regiões do mundo. O milho é, também, largamente empregado na alimentação animal como fonte energética, pois o amido do grão encontra-se numa forma facilmente digerível e de baixo custo.

De acordo com FNP Consultoria (2002), os números da safra 2002/2003 mostram que os principais produtores mundiais de milho são Estados Unidos (224 milhões de toneladas), China (125 milhões de toneladas), Brasil (37 milhões de toneladas), México (19 milhões de toneladas) e Argentina (12,5 milhões de toneladas), que contribuem, respectivamente, com $38 \%, 21 \%, 6 \%, 3 \%$ e $2 \%$ da produção mundial (585 milhões de toneladas). O Brasil, ocupa a primeira colocação no Mercosul, onde 
participa com $70 \%$ do total de milho produzido. Nesse bloco econômico a Argentina ocupa a segunda colocação, correspondendo a $28 \%$ da fração de mercado.

No âmbito nacional, a cultura de milho destaca-se como uma das mais importantes, tanto no aspecto econômico quanto no social, apresentando, de acordo com FNP Consultoria (2002), área cultivada de aproximadamente de 12 milhões de hectares e produção de cerca de 37 milhões de toneladas na safra de 2002/2003, colocando-se entre os principais grãos cultivados no país.

Vale ressaltar que a produtividade média brasileira encontra-se muito aquém do desejável, pois a média nacional corresponde a 2850 kg.ha ${ }^{-1}$ (safra 2001/2002), valor muito abaixo dos $8500 \mathrm{~kg} \mathrm{ha}^{-1}$, que representa a média de produtividade dos Estados Unidos, segundo levantamento efetuado pelo Departamento de Agricultura dos Estados Unidos em 2001.

\subsection{Fenologia}

De acordo com Marcos Filho (1997), o termo fenologia se refere ao estudo dos fenômenos periódicos da vida vegetal em função da sua reação às condições ambientais. Dourado Neto \& Fancelli (2000) citam que o conceito fenologia envolve o conhecimento de todas etapas de crescimento e desenvolvimento da vida vegetal, uma vez que a reunião desses conhecimentos, de forma ordenada e concisa, possibilita a determinação das relações e do grau de influência dos fatores envolvidos no processo produtivo, favorecendo o estabelecimento de estratégias de manejo e de tomada de decisão. Fancelli (1986) destaca que a fenologia é utilizável por ser uma referência exata, pois o manejo baseado em simples escala de tempo, como dias transcorridos após a semeadura, pode ocasionar equívocos dependendo das condições em que a cultura é submetida. $\mathrm{O}$ autor destaca que a condução da cultura deve ser baseada na fenologia, por considerar que há correlação entre eventos fisiológicos e bioquímicos (inerentes a cada etapa de desenvolvimento e crescimento da planta) e suas características morfológicas. Esse procedimento proporciona maior segurança e precisão nas ações de manejo.

Para maior facilidade de manejo e estudo, bem como objetivando estabelecer correlações entre eventos fisiológicos, climatológicos, entomológicos, fitopatológicos e 
fitotécnicos com o desempenho da planta, o período entre a emergência e ponto de maturidade fisiológica é descrito em 11 momentos (estádios) distintos (Fancelli,1986 e Fancelli \& Dourado Neto, 1997) (Tabela 1).

Tabela 1. Descrição sucinta dos estádios fenológicos da cultura de milho (Fancelli, 1986 e Fancelli \& Dourado Neto, 1997)

\begin{tabular}{cc}
\hline Estádio & Descrição \\
\hline 0 & $50 \%$ da plantas com 2 folhas completamente desenvolvidas (Emergência) \\
1 & $50 \%$ das plantas com 4 folhas completamente expandidas \\
2 & $50 \%$ das plantas com 8 folhas completamente expandidas \\
3 & $50 \%$ das plantas com 12 folhas completamente expandidas \\
4 & $50 \%$ das plantas emitindo o pendão \\
5 & $50 \%$ das plantas no início da polinização (Florescimento) \\
6 & $50 \%$ das plantas com grãos leitosos \\
7 & $50 \%$ das plantas com grãos pastosos \\
8 & $50 \%$ das plantas com grãos farináceos (formação de dentes) \\
9 & $50 \%$ das plantas com grãos farináceos duros (dentados) \\
10 & $50 \%$ das plantas com aparecimento da camada negra no ponto de \\
& inserção do grão com o sabugo (ponto de maturidade fisiológica) \\
\hline
\end{tabular}

Conforme relatado por Fancelli \& Dourado Neto (2000), o milho é uma planta de ciclo vegetativo muito variável, sendo que nas condições brasileiras, a cultura apresenta ciclo entre 110 e 180 dias, em função da caracterização dos híbridos (superprecoce, precoce e normal), período esse compreendido entre a semeadura e a colheita (interesse prático). De acordo com os autores, o ciclo da cultura compreende as seguintes etapas: (i) semeadura a emergência, que é o período compreendido desde a semeadura até o efetivo aparecimento da plântula (duas folhas completamente desenvolvidas), o qual, em função da temperatura e umidade do solo, pode ocorrer de 5 a 12 dias de duração, (ii) fase vegetativa, a qual é compreendida entre a emissão da segunda folha e o início do florescimento (polinização). Vale ressaltar que tal etapa apresenta extensão variável, 
sendo esse fato comumente empregado para caracterizar os tipos comerciais de híbridos de milho, (iii) fase reprodutiva, período compreendido entre o início da polinização e o ponto de maturidade fisiológica onde ocorre o enchimento completo dos grãos, sendo sua duração estimada entre 50 e 80 dias, e (iv) $\mathrm{O}$ ponto de maturidade fisiológica é determinado pelo aparecimento da camada negra no ponto de inserção do grão com o sabugo. Esse fato é um indicativo do final do ciclo de vida da planta. Porém, para fins práticos o ciclo pode ser computado até a colheita.

Fancelli (1986) destaca que folha completamente expandida é aquela que apresenta a linha de união lâmina-bainha (“colar") facilmente visível, e que o estádio (momento) é determinado quando $50 \%$ das plantas apresentam a descrição característica.

\subsection{Ecofisiologia e produtividade da cultura}

Conforme relatado por Silva \& Menten (1997), a cultura de milho está sujeita a fatores bióticos e abióticos que alteram a fisiologia e a morfologia da planta e, conseqüentemente, afetam a produtividade e a qualidade do produto. De acordo com os autores, os distúrbios abióticos são causados, dentre outros, por agentes como temperatura, deficiência nutricional, toxidez causada por substâncias químicas, fertilizantes e estresse hídrico. Os distúrbios bióticos são causados por fungos, bactérias, vírus, micoplasma e nematóides (doenças infecciosas), plantas daninhas e pragas, principalmente. Assim, todos esses fatores deverão ser considerados no planejamento e no manejo da cultura.

De acordo com Fancelli \& Dourado Neto (2000), dentre as estratégias básicas relacionadas à obtenção de produtividade elevada e lucrativa na cultura de milho, podem ser destacadas a escolha da época correta de semeadura para a região, o uso de genótipos adequados para as condições do ambiente de produção, o conhecimento pleno das etapas críticas da cultura, o emprego de recomendações e ações de intervenção fundamentadas em estádios fenológicos e a garantia do equilíbrio e do fornecimento de nutrientes em doses adequadas.

Fancelli \& Dourado Neto (1997) citam que a produtividade depende da população, prolificidade, número médio de fileiras de grãos por espiga, número médio 
de grãos por fileira e da massa média do grão ou semente. Destacam que a população e a prolificidade devem ser otimizadas levando em consideração o genótipo (especialmente arquitetura de planta), condições edafoclimáticas e tecnologia empregada.

Fancelli (1986) relata que o potencial de produtividade de milho é definido por ocasião da emissão da quarta folha, podendo se estender até a sexta folha, principalmente, em função da natureza protândrica dos principais genótipos utilizados no Brasil. O referido estádio está correlacionado à diferenciação floral, a qual também coincide com o término da fase de diferenciação das folhas. Portanto, nessa etapa já estará definida a área foliar potencial que aplanta deverá apresentar. Da mesma forma, a confirmação do número de fileiras (ovários) da espiga, ocorrerá entre o período correspondente à emissão da sétima e nona folha completamente expandidas, devido às transformações ocorridas na gema axilar que dará origem à espiga. A primeira gema axilar que muda do estado vegetativo para o estado reprodutivo é a gema superior, isto é, aquela posicionada entre a quinta e a sétima folha abaixo da panícula. $\mathrm{O}$ autor ressalta que o número de ovários e o número de óvulos contidos na espiga são afetados significativamente pela temperatura, pelo genótipo e pela disponibilidade de nitrogênio, sendo menos sensíveis à radiação solar e densidade de plantas. A baixa disponibilidade de nitrogênio (inferior a $25 \mathrm{~kg} \mathrm{ha}^{-1}$ ) e a presença de temperaturas baixas (inferior a $12^{\circ} \mathrm{C}$ ) no início do desenvolvimento da planta $\left(4^{\mathrm{a}} / 5^{\mathrm{a}}\right.$ folha) contribuem de forma decisiva para a redução do tamanho da raiz (redução de síntese de citocinina) e, conseqüentemente, do potencial de produtividade da cultura.

Ainda, Fancelli (1986) cita que o número médio de grãos por fileira é afetado pelo tamanho da espiga, a qual é definida, principalmente, no estádio 3 (plantas com 12 folhas). A massa média do grão (ou semente) é marcadamente afetada a partir do estádio 6 (grãos leitosos) principalmente pela disponibilidade de água e nutrientes. Por outro lado, qualquer estresse entre a emissão da $12^{\mathrm{a}}$ folha (estádio 3 ) e o pendoamento (estádio 4), reduz tanto a altura de planta como a área foliar.

Outros fatores importantes referentes à produtividade da cultura de milho estão relacionados ao índice de área foliar, uma vez que Fancelli (1986) ressalta que a redução do índice de área foliar (área foliar da cultura por unidade de área de solo explorado pela 
mesma) resulta na diminuição da taxa de interceptação de radiação solar com conseqüente redução de produção de carboidratos e produtividade. $\mathrm{O}$ referido autor destaca que, para a cultura de milho, os valores ótimos de interceptação da radiação incidente estão entre $90 \%$ e 95\% da área foliar máxima, sendo que os mesmos ocorrem em função de uma série de fatores (disponibilidade de água, temperatura, população e distribuição espacial de plantas na área e disponibilidade de nutrientes, principalmente).

\subsection{Importância dos nutrientes estudados para a cultura de milho}

Conforme relatado por Büll (1993), a obtenção de altas produtividades na cultura de milho é indispensável para tomar a cultura economicamente viável e a adubação é um dos fatores essenciais para a garantia da produtividade, uma vez que o fornecimento de nutrientes de forma correta, no momento correto e em doses adequadas, proporcionam o máximo desenvolvimento da cultura.

Segundo Malavolta et al. (1997), um elemento é considerado essencial à cultura quando satisfaz tanto os critérios diretos, como os critérios indiretos de essencialidade. De acordo com o autor, critério direto é quando o elemento participa de algum composto ou de alguma reação, sem o qual a planta não vive. Sendo assim, na ausência do elemento a planta não completa o seu ciclo de vida. Critério indireto é quando o elemento apresenta efeito na vida da planta, porém sua ação não consiste na anulação de condições físicas, químicas ou biológicas desfavoráveis presentes no substrato. Dechen et al. (1991) relatam que para o elemento ser considerado essencial, ele deve estar diretamente envolvido no metabolismo da planta, como constituinte de um composto essencial, ou ser necessário para a ação de um sistema enzimático.

Raij (1991a) cita que se um elemento é essencial para a vida vegetal, sem ele as plantas não completam o seu ciclo de vida. Destaca também que os nutrientes essenciais estão divididos em macronutrientes e micronutrientes, de acordo com o teor nas plantas e com a quantidade em que é exigido pelas mesmas. Assim, denomina-se macronutrientes aqueles que as plantas exigem em maiores quantidades para exercerem suas funções, enquanto micronutrientes são aqueles que a cultura requer em menores quantidades. Dentre os nutrientes considerados essenciais para as plantas, seis são 
macronutrientes (Nitrogênio - N, Potássio - K; Fósforo - P; Cálcio - Ca; Magnésio - Mg e Enxofre - S) e sete são micronutrientes (Boro - B; Cloro - $\mathrm{Cl}$; Cobre - Cu; Ferro - Fe; Manganês - Mn; Molibdênio - Mo e Zinco - Zn), sendo que a filta de qualquer um deles pode limitar o crescimento e o desenvolvimento da planta, mesmo que todos os outros estejam presentes em quantidades adequadas. Dessa maneira, Raij (1991a) coloca que as quantidades relativas de nutrientes no solo determinam a sua disponibilidade e devem ser consideradas tanto quanto as quantidades absolutas de cada um.

Segundo Lopes (1999), a agricultura brasileira passa por uma fase em que a produtividade, a eficiência, a lucratividade e a sustentabilidade dos processos produtivos são extremamente relevantes, uma vez que os micronutrientes passaram a ser utilizados de modo mais rotineiro nas adubações da cultura de milho, em todas as regiões brasileiras e para as mais variadas condições de solo e clima. De acordo com o autor, os principais motivos que despertaram o interesse dos produtores brasileiros de milho, pela utilização de fertilizantes contendo micronutrientes foram: (i) o início da ocupação da região dos cerrados, formada naturalmente por solos deficientes em micronutrientes; (ii) o aumento da produtividade da cultura com maior remoção e exportação de todos os nutrientes; (iii) a falta de critérios para a aplicação de calcário, no que diz respeito a doses e metodologias de aplicação, o que induziu o aparecimento de deficiências de vários elementos, como zinco, por exemplo; (iv) a preferência por aplicações apenas de macronutrientes, como nitrogênio, fósforo e potássio, reduzindo o uso de micronutrientes por muitos anos; e (v) o aprimoramento das técnicas de análise de solos e análise foliar como instrumentos de diagnose de deficiências de micronutrientes.

Lopes (1991) destaca que, por ocasião da semeadura, a viabilidade da aplicação de fontes de micronutrientes combinadas a fontes de macronutrientes é muito maior do que aplicá-los separadamente, uma vez que, devido às baixas doses utilizadas, a uniformidade de distribuição dos micronutrientes no sulco de semeadura pode ser prejudicada. Dessa maneira, as fontes de macronutrientes e micronutrientes podem estar combinadas através de mistura de grânulos (em que cada grânulo da mistura é constituído de uma única fonte, como sulfato de zinco e uréia, por exemplo) ou de fertilizantes granulados (um único grânulo apresenta em sua composição todos os 
elementos desejados, como nitrogênio, fósforo, potássio, boro e zinco). O autor cita também que o uso de fertilizantes granulados propicia maior uniformidade na distribuição de todos os elementos no sulco de semeadura, uma vez que, ao misturar grânulos de diferentes fontes, como ácido bórico e sulfato de zinco misturados a alguma formulação de NPK, ocorre segregação devido à desuniformidade no tamanho dos grânulos.

Para a cultura de milho, vários autores citam que o nitrogênio é um dos macronutrientes absorvidos em maior quantidade, o que o torna um dos mais importantes e mais estudados por pesquisadores do mundo todo. Com relação aos micronutrientes, além de Malavolta et al. (1987), vários autores relatam que os elementos boro e zinco têm extrema importância para a cultura de milho, devido ao alto índice de deficiência no Brasil, ou seja, são os elementos em que os sintomas de deficiência são mais freqüentes.

\subsubsection{Nitrogênio}

Segundo Cobucci (1991), o nitrogênio é um dos nutrientes que apresentam os maiores efeitos no aumento de produtividade da cultura de milho, sendo que, aplicações de nitrogênio podem interferir em diversas características da planta relacionadas ao crescimento e desenvolvimento, as quais, direta ou indiretamente, afetam a produtividade da cultura. De acordo com o autor, na literatura são encontrados uma série de trabalhos com citações sobre a influência do nitrogênio no aumento da massa de mil grãos, do número de espigas por planta, da altura de plantas, da massa de espigas, do comprimento da espiga, do diâmetro do colmo e da produção de matéria seca.

Büll (1993) cita que além de ser constituinte de diversas moléculas de proteína, e outras, o nitrogênio apresenta importante função como integrante da molécula de clorofila. De acordo com o autor, o aumento de produtividade na cultura de milho proporcionado pelo nitrogênio pode ser atribuído aos efeitos positivos sobre o crescimento radicular e sobre o aumento do comprimento da espiga. Yamada (1996) também destaca que o nitrogênio é um elemento constituinte de moléculas de proteínas, coenzimas, ácidos nucléicos e citocromos, sendo o nutriente que a cultura de milho mais 
responde em produtividade de grãos.

Segundo Yamada (1996), o nitrogênio é absorvido pelas plantas de milho, principalmente, na forma nítrica, que posteriormente é reduzida a amônio, num processo onde estão envolvidas duas enzimas, a redutase de nitrato e a redutase de nitrito, sendo que a primeira é responsável pela transformação de nitrato em nitrito e a segunda pela transformação de nitrito em amônio, para posterior assimilação em aminoácidos.

Büll (1993) relata que o nitrogênio é o elemento mais exportado pelas plantas de milho, uma vez que a cada tonelada de grãos produzida são exportados aproximadamente $15 \mathrm{~kg}$ de nitrogênio. Assim, Yamada (1996) ressalta que para uma produtividade esperada de 10 toneladas de grãos por hectare, deve-se aplicar entre $150 \mathrm{e}$ $200 \mathrm{~kg} \cdot \mathrm{ha}^{-1}$ de nitrogênio. Büll (1993) ressalta que a magnitude das respostas de nitrogênio em ensaios conduzidos no Brasil tem sido variável, porém a maioria dos estudos indica respostas significativas entre 30 e $90 \mathrm{~kg}_{\mathrm{h}} \mathrm{ha}^{-1}$ de $\mathrm{N}$, devido aos níveis de produtividade relativamente baixos. $\mathrm{O}$ autor salienta que não são incomuns casos de respostas a até $200 \mathrm{~kg} \cdot \mathrm{ha}^{-1}$ de $\mathrm{N}$ para a cultura de milho.

Raij et al. (1981) conduziram 25 ensaios com nitrogênio e conseguiram observar reação positiva das plantas de milho em 16 deles, sendo que, em alguns casos, o aumento da produtividade de grãos com a aplicação de $120 \mathrm{~kg}^{-h a^{-1}}$ de $\mathrm{N}$ atingiu 5.000 $\mathrm{kg}_{\mathrm{g}} \mathrm{ha}^{-1}$. Nesse trabalho, o aumento médio de produtividade, para o conjunto de experimentos conduzidos, foi de aproximadamente $1500 \mathrm{~kg}_{\mathrm{ha}}{ }^{-1}$ de grãos para aplicações de até $120 \mathrm{~kg} \cdot \mathrm{ha}^{-1}$ de N.

De acordo com Büll (1993), a maioria dos estudos realizados mostra que os melhores resultados são obtidos com a aplicação de $30 \mathrm{~kg} \cdot h \mathrm{~h}^{-1}$ de $\mathrm{N}$ na semeadura e de 90 a $120 \mathrm{~kg} \cdot \mathrm{ha}^{-1}$ entre 30 e 45 dias após a germinação, totalizando entre 120 e 150 kg.ha- ${ }^{-1}$ de N. Sá (1989), avaliando as respostas da adubação nitrogenada sobre a

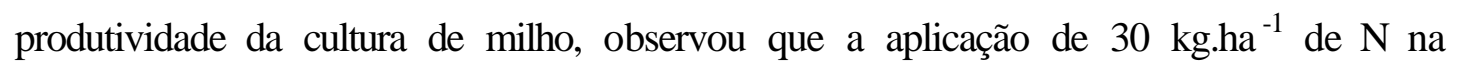
semeadura e $90 \mathrm{~kg} \mathrm{ha}^{-1}$ de $\mathrm{N}$ em cobertura proporcionou produtividade de grãos de aproximadamente $11.000 \mathrm{~kg} \mathrm{ha}^{-1}$. Yamada (1996) também relata que a aplicação de 30 kg.ha ${ }^{-1}$ de nitrogênio no sulco de semeadura e do restante $\left(90 \mathrm{~kg} \cdot \mathrm{ha}^{-1} \mathrm{de} \mathrm{N}\right)$ em cobertura proporcionou maior produtividade de grãos do que quando foram aplicados $15 \mathrm{~kg} \cdot \mathrm{ha}^{-1}$ de 
nitrogênio por ocasião da semeadura e $105 \mathrm{~kg} \cdot \mathrm{ha}^{-1}$ de nitrogênio em cobertura. Ferreira (1997), ao efetuar a aplicação de doses crescentes de nitrogênio na cultura de milho (0, 70, 140 e $210 \mathrm{~kg} \cdot \mathrm{ha}^{-1}$ ), observou que a máxima produtividade foi obtida mediante a aplicação de $200 \mathrm{~kg} \cdot \mathrm{ha}^{-1}$ de nitrogênio.

Quanto ao modo e à posição de aplicação do fertilizante nitrogenado na cultura de milho, Yamada (1996) cita que parte deve ser aplicada por ocasião da semeadura, posicionado 5 centímetros abaixo e 5 centímetros ao lado da semente, e o restante em cobertura após a emergência das plantas, pois, de acordo com o trabalho desenvolvido por Zublena \& Anderson (1994), o fertilizante nitrogenado, se aplicado muito próximo das sementes, pode reduzir a emergência devido à salinidade ou à toxidez por amônia. De acordo com Oliveira (1995), a aplicação em cobertura de nitrogênio deve ser localizada em faixa, na entrelinha da cultura, e não a lanço, a fim de evitar o contato do fertilizante com as folhas da planta o que pode provocar a desidratação e morte das células da epiderme e, conseqüentemente, o aparecimento de lesões.

\subsubsection{Zinco}

Conforme relatou Büll (1993) o zinco é o micronutriente mais limitante à produtividade de milho no Brasil, sendo que os relatos de deficiência desse elemento para o milho provém, principalmente, de solo Argissolo Vermelho-Amarelo ou Latossolos altamente intemperizados e ácidos da região dos cerrados.

O zinco é considerado um elemento de grande importância para a cultura de milho, uma vez que, de acordo com Borkert (1989), uma das mais importantes funções desse elemento na planta de milho é participar como componente de um grande número de enzimas como as desidrogenases, proteinases, peptidases e fosfohidrolases, sendo que as funções básicas na planta estão relacionadas ao metabolismo dos carboidratos, das proteínas e dos fosfatos, e na formação da estrutura das auxinas, RNA e ribossomos. Segundo Malavolta et al. (1991), o zinco também está relacionado ao metabolismo de fenóis, à formação de amido, ao aumento no tamanho e multiplicação celular e à fertilidade do grão de pólen. Decaro et al. (1983) citam que resultados obtidos por diversos autores mostram efeitos positivos do zinco perante a cultura de milho, o qual 
proporciona aumento da altura das plantas, do número de folhas, da produção de forragem e de grãos, bem como aumento do conteúdo total de proteína nos grãos. Dessa maneira, vários trabalhos conduzidos em casa-de-vegetação e campo têm demonstrado que a adição de zinco promoveu aumentos significativos na produtividade de milho (Galrão \& Mesquita Filho, 1981; Souza et al., 1985; Galrão, 1995).

Com relação aos níveis de zinco nas folhas de milho, Rosolem \& Franco (2000) consideram como ideais níveis entre 20 e $70 \mathrm{mg} \cdot \mathrm{kg}^{-1}$. Malavolta et al. (1997) coloca que o ideal é que as folhas das plantas de milho apresentem entre 15 e $50 \mathrm{mg} . \mathrm{kg}^{-1}$, por ocasião do florescimento, enquanto Galrão (1995) cita o valor de $18,5 \mathrm{mg} \cdot \mathrm{kg}^{-1}$ como sendo o nível crítico de zinco nas folhas da cultura de milho. Segundo Furlani \& Furlani (1996) e Bataglia \& Dechen (1986), o nível crítico para a cultura de milho é de 17 mg.kg ${ }^{-1}$ de $\mathrm{Zn}$ na matéria seca de folhas maduras recém expandidas e que, de acordo com Jones Jr. (1972), sintomas de fitotoxidez podem surgir para níveis acima de 400 mg.kg ${ }^{-1}$ de Zn na matéria seca. Apesar dessas afirmações, Rosolem \& Franco (2000), ao estudarem a relação entre a translocação do zinco e o crescimento radicular de plantas de milho, observaram que níveis de zinco iguais ou maiores que $12 \mathrm{mg} \cdot \mathrm{kg}^{-1}$ foram suficientes para proporcionar crescimento normal às raízes. É importante ressaltar que Malavolta et al. (1991) destacam que para cada onelada de grãos de milho produzidos, são exportados 85 gramas de zinco.

Fancelli \& Dourado Neto (2000) consideram adequados para a cultura de milho o teor de zinco no solo entre 0,5 e $1,0 \mathrm{mg} \cdot \mathrm{kg}^{-1}$. Esses valores concordam com os apresentados por Brown et al. (1971), Cox \& Kamprath (1972) e Buzetti et al. (1991). Cabe salientar que, de acordo com Abreu (1996), os níveis ideais de zinco no solo (extraído através da solução de ácido Dietileno-Triamino-Penta-Acético - DTPA) estão situados entre 0,5 e $1,2 \mathrm{mg} \cdot \mathrm{dm}^{-3}$.

Conforme relatado por Furlani \& Furlani (1996), no Brasil, o primeiro relato de deficiência de zinco na cultura de milho foi efetuado por Igue \& Gallo em 1960. Malavolta \& Dantas (1987) e Coelho \& França (1995) descrevem que os sintomas de deficiência de zinco em plantas de milho são caracterizados por internódios curtos (redução na altura das plantas) e faixas brancas ou amarelas entre a nervura principal e 
as bordas das folhas novas, principalmente nas folhas que estão se desenrolando na região de crescimento, uma vez que tais folhas podem, posteriormente, apresentar tons roxos e necrose. Segundo Barbosa Filho (1987), uma das consequiências da deficiência de zinco nas plantas de milho é o encurtamento do internódio, resultando em redução do crescimento, o que ocorre devido ao fato do zinco ser necessário à produção de triptofano que é um aminoácido precursor do ácido indol-acético, hormônio vegetal promotor do crescimento. Furlani \& Furlani (1996) também descrevem que os sintomas de deficiência de zinco em plantas de milho aparecem nas folhas mais novas, as quais ficam com tamanho reduzido e formam roseta, devido ao encurtamento dos internódios. Os referidos autores, ao estudarem diferentes doses de zinco aplicadas em 24 genótipos de milho, durante 30 dias, constataram alta correlação entre a altura das plantas e o teor de zinco na parte aérea, concluindo que a altura de plantas é a variável que melhor reflete o estresse provocado por baixos níveis do elemento nas plantas de milho. De acordo com Borkert (1989), a deficiência de zinco reduz o crescimento das plantas de milho e diminui a síntese de clorofila na lâmina foliar, como também o metabolismo do nitrogênio.

Raij (1991b) cita que o zinco é um elemento cuja forma mais comum em solução é a do cátion $Z^{2+}$ e que, conforme relatado por Lopes (1999), movimenta-se por difusão no solo, ou seja, dos pontos de maior concentração para os pontos de menor concentração, sendo que a maior disponibilidade ocorre na faixa de $\mathrm{pH}$ de solo entre 5,0 e 6,5. Há relatos de que quando o pH é elevado para valores acima de 6,0, foram observados sintomas de deficiência de zinco nas plantas. Büll (1993) relatou que ao elevar o $\mathrm{pH}$ do solo, a solubilidade do zinco diminuiu e os sintomas de deficiência aumentaram, principalmente em plantas cultivadas em solos pobres. Tal fato pode ser explicado através da afirmação de Raij (1991b) que coloca que sob condições de pH elevado, o zinco precipita na forma de hidróxido de zinco insolúvel e se torna indisponível para as plantas. Quaggio (2000) também cita que a disponibilidade de zinco no solo é diretamente afetada pelo $\mathrm{pH}$, uma vez que ao elevar o $\mathrm{pH}$ do solo a disponibilidade do referido micronutriente é diminuída, devido ao aumento da retenção no complexo coloidal ou àredução da solubilidade de suas fontes. 
Lopes (1999) cita que o zinco pode ser fortemente adsorvido pelos colóides do solo, o que ajuda a diminuir as perdas por lixiviação, porém pode dificultar a absorção pelas plantas em alguns casos e também provocar deficiências. Rosolem \& Franco (2000) colocam que tal adsorção pode ser influenciada por várias propriedades e características do solo como $\mathrm{pH}, \mathrm{CTC}$, teor de matéria orgânica, teor de cátions e ânions solúveis, tipo de argila e teor de argila, óxidos e hidróxidos de ferro e alumínio. É válido ressaltar que vários trabalhos citam que a deficiência de zinco tem sido observada em solos com alto teor de argila devido à ação quelante que a mesma exerce sobre íons metálicos como o $\mathrm{Zn}$, resultando em complexos organo-minerais que não podem ser absorvidos pelas plantas. Quanto aos teores de argila, sabe-se que a adsorção de zinco pelo solo é maior à medida que aumentam os teores de argila, salientando que esse processo não ocorre igualmente em todos os solo argilo-minerais. Em geral, argila do tipo 2:1 apresenta maior capacidade de retenção de $\mathrm{Zn}$ devido à penetração do referido íon na camada octaédrica dos argilo-minerais.

Galrão (1994) cita que a resposta da cultura de milho à aplicação de zinco via foliar nem sempre é positiva, sendo que, muitas vezes é necessária a aplicação do referido elemento via solo. $\mathrm{O}$ referido autor efetuou um estudo com diferentes formas de aplicação de sulfato de zinco na cultura de milho e observou que, para uma mesma dose (1,2 kg.ha- ${ }^{-1}$ de $\left.\mathrm{Zn}\right)$ a produtividade de grãos foi maior (7.365 kg.ha $\left.{ }^{-1}\right)$ quando se aplicou o referido fertilizante a lanço do que no sulco de semeadura (5.598 kg.ha-1).

Melarato (2000) cita que o zinco é o micronutriente que apresenta as maiores respostas de produtividade de grãos na cultura de milho e que, geralmente, as doses recomendadas são de 2 a 4 kg.ha ${ }^{-1}$. Esses valores são semelhantes aos descritos por Raij et al. (1985), que recomendam de 2,5 a 5,0 $\mathrm{kg} \cdot \mathrm{ha}^{-1}$ de $\mathrm{Zn}$ para a cultura de milho no Brasil. Galrão (1994) verificou aumento na produtividade de grãos de milho mediante a aplicação de 1,2 kg.ha ${ }^{-1}$ de zinco num Latossolo Vermelho Escuro, tanto a lanço como no sulco de semeadura. Souza et al. (1998), ao avaliarem a resposta da cultura de milho à adição de doses crescentes de zinco no sulco de semeadura, observaram que a adição de zinco promoveu incrementos significativos na produtividade de grãos e nos teores de micronutriente nas folhas, porém não verificaram vantagens em aplicar doses superiores 
a 5 kg.ha ${ }^{-1}$ de zinco. No referido trabalho, os autores destacam que aplicaram doses de até $20 \mathrm{~kg}_{\text {.ha }}{ }^{-1}$ de zinco no sulco de semeadura de milho e não verificaram nenhum sintoma visível de fitotoxidez ou queda da produtividade de grãos.

Galrão \& Mesquita Filho (1981) estudaram o efeito de fontes de zinco para a cultura de milho em solos argilosos e concluíram que tanto o sulfato de zinco como o óxido de zinco ou as fritas têm a mesma eficiência quanto à produção de matéria seca, desde que aplicados corretamente. Os referidos autores verificaram também que o teor de zinco no solo aumentou em função do aumento das doses aplicadas (0, 1,25, 2,5, 5,0 e $10,0 \mathrm{mg} \cdot \mathrm{kg}^{-1}$ ), independentemente das fontes utilizadas (sulfato, óxido ou FTE) e da dose de calcário aplicada (1,0 ou 2,6 t.ha $\left.{ }^{-1}\right)$. Malavolta et al. (1987), ao avaliarem a eficiência relativa das fontes de zinco para o milho, observaram que em solos arenosos as plantas responderam diferentemente às fontes utilizadas (óxido de zinco, sulfato de zinco e fritas FTE Br-12), sendo que a aplicação de altas doses de sulfato de zinco (maior que 1,0 mg. $\mathrm{kg}^{-1}$ ) provocou fitotoxidez à cultura e reduziu a produção de matéria seca, enquanto as outras fontes estudadas não mostraram tendência para toxidez. Os referidos autores destacam que não se observou efeito tóxico provocado pelas duas fontes insolúveis (fritas FTE Br-12 e óxido de zinco) quando fornecidas na mesma dose que a fonte solúvel (sulfato de zinco), o que pode ser explicado devido à alta disponibilidade inicial do elemento para a planta, quando fornecido através de fonte solúvel, o qual elevou-se exageradamente nos tecidos (atingiu níveis de $40 \mathrm{mg} \cdot \mathrm{kg}^{-1}$ ). Os autores relatam ainda que Galrão \& Mesquita (1981), ao realizarem um ensaio em vasos, não verificaram efeito tóxico à cultura de milho mediante a aplicação de altas doses (até 10 mg. $\mathrm{kg}^{-1}$ ) de sulfato de zinco, o que pode ser explicado devido ao fato dos autores terem utilizado solo argiloso ao invés de solo arenoso.

\subsubsection{Boro}

O boro é considerado um micronutriente essencial e sua deficiência, juntamente com a de zinco, é a mais freqüente no Brasil.

Segundo Mengel \& Kirkby (1987), o boro é absorvido pelas plantas na forma de ácido bórico ou de borato, sendo que é um elemento considerado imóvel no floema. 
Conforme relatado por Brown \& Hu (1998), o boro é considerado móvel no floema apenas em espécies de plantas que utilizam polióis (açúcares simples) como um metabólito fotossintético primário, pois nessas espécies (macieiras, amendoeiras e nectarinas, por exemplo) um complexo poliol-B-poliol é formado nos tecidos fotossintéticos e transportado no floema para drenos ativos, como meristemas vegetativos ou reprodutivos. Porém, o mesmo não acontece nas plantas de milho, as quais não produzem quantidades significativas de polióis. Nessas, o boro é transportado pelo xilema, através do fluxo transpiratório, até um determinado órgão da planta onde permanece imóvel, não se redistribuindo para outras partes.

Yamada \& Lopes (1998) citam que a imobilidade do boro em plantas de milho é comprovada pela ocorrência de teores mais altos de boro em folhas velhas, quando comparadas a folhas mais jovens, principalmente em situações de deficiência do elemento na planta. Assim, os referidos autores sugerem que a aplicação de boro para a cultura de milho deve ser efetuada no solo para que seja plenamente aproveitado pela planta, uma vez que, se aplicado via foliar, não será retranslocado do local de aplicação e não suprirá as exigências dos tecidos a serem formados (tecidos jovens).

Segundo Malavolta et al. (1991), o boro tem importante papel na organização e no funcionamento de membranas (atividade da ATPase e absorção iônica), no florescimento, na germinação do grão de pólen e no crescimento do tubo polínico, bem como atua no metabolismo de auxinas (ácido indol acético, por exemplo), fenóis e lignificação da parede celular. Dechen (1988) e Borkert (1989) relatam que as funções do boro na planta de milho são relacionadas a alguns processos básicos, como o metabolismo de carboidratos e o transporte de açúcares através das membranas, a síntese de ácidos nucléicos (ácido ribonucléico e ácido desoxiribonuckéico) e de fitormônios, a formação de paredes celulares, a divisão celular e o desenvolvimento de tecidos. Destacam que o boro forma complexos açúcar-borato relacionados com a translocação de açúcares na planta, pois os complexos atravessam mais facilmente as membranas celulares, uma vez que as moléculas de açúcares possuem alta polaridade. De acordo Yamada (2000), o boro é considerado elemento fundamental para o desenvolvimento radicular das plantas de milho, sendo necessária a sua presença no solo, em teores 
adequados, para que o sistema radicular se desenvolva plenamente.

Segundo Fancelli \& Dourado Neto (2000), os teores críticos de boro no solo para a cultura de milho estão compreendidos entre 0,1 e $0,3 \mathrm{mg} \cdot \mathrm{kg}^{-1}$. Abreu (1996) cita que os teores ideais de boro no solo (extraído pelo método de água quente) estão situados entre 0,20 e $0,60 \mathrm{mg} \cdot \mathrm{dm}^{-3}$.

Com relação aos teores de boro nas folhas de milho, Malavolta et al. (1989) citam que o ideal é que as mesmas apresentem entre 15 e $20 \mathrm{mg} \cdot \mathrm{kg}^{-1}$ por ocasião do florescimento.

De acordo com Yamada \& Lopes (1998), as diferenças no local de acúmulo de boro nas plantas, a qual é determinada pela mobilidade do elemento no floema, determinam em quais tecidos (jovens ou velhos) serão mais evidentes os sintomas de deficiência e de fitotoxidez. Assim, em espécies em que o boro é imóvel e não se transloca das partes mais velhas da planta para tecidos meristemáticos (raízes ou extremidades das partes aéreas), como na cultura de milho, normalmente, os sintomas de deficiência são observados primeiramente nas partes mais jovens, sendo caracterizado pela interrupção do crescimento das partes terminais e pela secagem de folhas novas (Raij, 1991b). Mozafar (1987) demonstrou a ação pronunciada do boro na formação de espigas na cultura de milho, e observou que a interrupção no fornecimento de boro conduziu à má formação e ao atrofiamento das espigas, além de falhas na granação. Fancelli \& Dourado Neto (2000) citam que plantas de milho deficientes em boro apresentam espigas pequenas, falhas na granação, folhas avermelhadas no final do ciclo e extremidades das espigas com aspecto de cortiça.

Segundo Woodruff et al. (1987), em um experimento envolvendo variações nas doses de diversos nutrientes, incluindo o boro, com população entre 70.000 e 80.000 plantas de milho por hectare, observaram efeitos benéficos do boro sobre a produtividade de grãos, sugerindo que aplicações de boro podem ser necessárias quando se intensifica o uso de práticas para o aumento da produtividade associado a adubações elevadas, principalmente, com potássio. Por outro lado, Büll (1993) observa que, de forma geral, as respostas da cultura de milho a aplicações de boro não são consistentes, sendo que Touchton \& Boswell (1975) verificaram que aplicações de boro, tanto via 
solo como foliar, não influenciaram a produtividade de grãos. Peck et al. (1969) obtiveram correlação negativa entre a produtividade de grãos e teores de boro na folha, e que Abreu \& Lopes (1985) não observaram respostas da cultura de milho à aplicação desse micronutriente.

Com relação aos fatores que afetam a disponibilidade dos micronutrientes para as plantas, Lopes (1999) ressalta que a disponibilidade do boro é maior quando o pH do solo encontra-se na faixa compreendida entre 5,0 e 7,0, e que condições de seca podem interferir negativamente no aproveitamento do nutriente pelas plantas, uma vez que, sob condições de seca, a decomposição da matéria orgânica é diminuída, liberando menos boro para o solo, e o crescimento radicular é afetado, explorando menor volume de solo e reduzindo o índice de absorção do referido nutriente. Pavan \& Correa (1988), ao estudarem a adsorção do boro pelo solo, verificaram que a mesma foi abruptamente aumentada quando o $\mathrm{pH}$ do solo era maior que 6,5. Os autores atribuíram esses resultados aos efeitos do $\mathrm{pH}$ no aumento do número de sítios trocáveis na superfície da argila e na distribuição relativa entre as formas iônicas de B presentes na solução do solo, sendo que todos os solos utilizados no estudo adsorveram menores quantidades de boro em $\mathrm{pH}$ inferior a 6,5, provavelmente por causa do menor número de sítios de adsorção e pela maior proporção de ácido bórico molecular $\left[\mathrm{B}(\mathrm{OH})_{3}\right]$ em relação ao íon borato $\left[\mathrm{B}(\mathrm{OH})_{4}^{-}\right]$nessa faixa de $\mathrm{pH}$, indicando menor afinidade da argila pelo íon $\left[\mathrm{B}(\mathrm{OH})_{3}\right]$, ou seja, quanto maior a proporção do íon borato em relação ao ácido bórico molecular, maior adsorção do elemento boro pelo solo. Pavan \& Correa (1988) citam também que, ao contrário do observado por eles, Ribeiro \& Braga (1974) não observaram correlação entre a adsorção de boro, o tipo de argila e o teor de matéria orgânica em Latossolos de Minas Gerais.

Quanto à necessidade de boro pela cultura de milho, Malavolta et al. (1991) citam que a cada tonelada de grãos produzida são exportados 13 gramas de boro. De acordo com Yamada \& Lopes (1998), geralmente, as doses de boro recomendadas para a cultura de milho são de 0,5 a $1,0 \mathrm{~kg} \cdot \mathrm{ha}^{-1}$.

Em muitos casos, a adição de boro na adubação da cultura de milho é vantajosa. Há risco relativo ao uso de doses elevadas desse elemento, principalmente quando 
concentrado no sulco de semeadura. Muitos trabalhos previnem a aplicação de maiores doses de boro no solo, que as atualmente praticadas, por afirmarem que a faixa entre a deficiência e a fitotoxidez de boro na planta seria muito estreita (Yamada, 2000). Woodruff et al. (1987) e Büll (1993) também relatam que o limite entre os teores de fitotoxidez e deficiência de boro para a cultura de milho é muito estreito. Por outro lado, não há evidência que suporte a idéia da faixa estreita entre deficiência e fitotoxidez de boro (Chapman et al., 1997; Yamada, 2000).

Lopes (1991) salienta que ao utilizar fertilizantes contendo boro, se os mesmos forem aplicados no sulco de semeadura, deve-se posicioná-los com distância mínima de $5 \mathrm{~cm}$ das sementes devido ao risco do referido elemento provocar fitotoxidez às plântulas, mesmo quando aplicado em pequenas doses. 


\section{MATERIAL E MÉTODOS}

\subsection{Local do experimento}

O experimento de campo foi conduzido no município de Piracicaba, Estado de São Paulo, na área do Departamento de Produção Vegetal da Escola Superior de Agricultura "Luiz de Queiroz", Universidade de São Paulo, cujas coordenadas geográficas são $22^{\circ} 43^{\prime} 12^{\prime}$ ' latitude Sul e 47³8'54" longitude Oeste, com altitude de 580 metros.

\subsection{Caracterização física e química do solo}

O solo do local em que o experimento foi conduzido é classificado como Nitossolo Vermelho eutrófico textura argilosa/muito argilosa.

A Tabela 2 mostra a composição química do solo, de acordo com o Laboratório de Análise de Solos e Plantas pertencente ao Departamento de Solos e Nutrição de Plantas da ESALQ/USP.

Tabela 2. Resultado da análise química de solo da área experimental

\begin{tabular}{|c|c|c|c|c|c|c|c|c|c|c|c|c|}
\hline $\begin{array}{c}\mathrm{pH} \\
\mathrm{CaCl}_{2}\end{array}$ & $\begin{array}{c}\mathrm{MO} \\
\%\end{array}$ & $\begin{array}{c}\mathrm{P} \\
\mathrm{mg} \cdot \mathrm{kg}^{-1}\end{array}$ & $\bar{K}$ & $\mathrm{Ca}$ & & $\begin{array}{l}\overline{\mathrm{H}+\mathrm{A}} \\
\mathrm{ol} \cdot \mathrm{d}\end{array}$ & ${ }^{-3}$ & $\mathrm{~T}$ & $\begin{array}{l}\mathrm{V} \\
\%\end{array}$ & $\overline{\mathrm{B}^{3}}$ & $\begin{array}{c}\mathrm{Cu} \quad \mathrm{Fe} \quad \mathrm{Mn} \\
\mathrm{mg} \cdot \mathrm{dm}^{-3}\end{array}$ & $\overline{\mathrm{Zn}^{3}}$ \\
\hline $5,3^{(1)}$ & 3,3 & 53 & 5,5 & 45 & 16 & 34 & 66,5 & 100,5 & 66 & 0,35 & $\begin{array}{lll}5,8 & 36 & 51,4\end{array}$ & $\overline{2,0}$ \\
\hline $5,2^{(2)}$ & 3,1 & 33 & 5,3 & 42 & 17 & 34 & 64,3 & 98,3 & 65 & 0,32 & $6,2 \quad 41 \quad 57,4$ & 2,1 \\
\hline
\end{tabular}

\subsection{Informações meteorológicas}

As informações meteorológicas foram fornecidas pelo posto meteorológico 
automatizado pertencente ao Departamento de Ciências Exatas da ESALQ/USP, instalado em Piracicaba, SP (Tabela 3).

Tabela 3. Valores de radiação global média $\left(\mathrm{RGM}, \mathrm{cal} \cdot \mathrm{cm}^{-2} \cdot \mathrm{dia}^{-1}\right)$, precipitação total $(\mathrm{P}$, mm), umidade relativa média (UR, \%) do ar (determinada às 7:00h), temperatura $\left({ }^{\circ} \mathrm{C}\right)$ do ar (temperaturas máxima, mínima e média), e evaporação total do tanque classe $\mathrm{A}(\mathrm{E}, \mathrm{mm})$ por decêndios, registrados durante o período de condução do experimento

\begin{tabular}{llcccccccc}
\hline Ano & Mês & Decêndio & $\begin{array}{c}\text { RGM } \\
\left(\mathrm{cal.cm}^{-2} \cdot \mathrm{dia}^{-1}\right)\end{array}$ & $\begin{array}{c}\text { P } \\
(\mathrm{mm})\end{array}$ & $\begin{array}{c}\text { UR } \\
(\%)\end{array}$ & Máxima & Mínima & Média & $(\mathrm{mm})$ \\
\hline 2000 & Out & 1 & 483,0 & 21,5 & 68,0 & 31,3 & 16,7 & 24,0 & 56,0 \\
2000 & Out & 2 & 495,0 & 9,5 & 63,0 & 34,1 & 19,1 & 26,6 & 62,0 \\
2000 & Out & 3 & 462,0 & 83,0 & 74,0 & 31,0 & 18,2 & 24,6 & 54,0 \\
2000 & Nov & 1 & 513,0 & 43,2 & 70,0 & 31,1 & 17,7 & 24,4 & 61,0 \\
2000 & Nov & 2 & 429,0 & 88,9 & 80,0 & 27,9 & 17,3 & 22,6 & 54,0 \\
2000 & Nov & 3 & 454,0 & 107,1 & 82,0 & 30,5 & 18,2 & 24,3 & 58,0 \\
2000 & Dez & 1 & 490,0 & 43,9 & 76,0 & 29,9 & 18,5 & 24,2 & 58,0 \\
2000 & Dez & 2 & 387,0 & 70,5 & 81,0 & 29,0 & 18,5 & 23,7 & 54,0 \\
2000 & Dez & 3 & 465,0 & 81,8 & 85,0 & 30,4 & 19,9 & 25,2 & 59,0 \\
2001 & Jan & 1 & 545,0 & 12,0 & 72,0 & 32,2 & 19,0 & 25,6 & 66,0 \\
2001 & Jan & 2 & 537,0 & 95,1 & 71,0 & 32,3 & 19,6 & 26,0 & 65,0 \\
2001 & Jan & 3 & 451,0 & 122,5 & 83,0 & 31,3 & 20,1 & 25,7 & 58,0 \\
2001 & Fev & 1 & 433,0 & 51,7 & 84,0 & 30,9 & 21,0 & 26,0 & 60,0 \\
2001 & Fev & 2 & 421,0 & 33,2 & 84,0 & 31,4 & 20,4 & 25,9 & 59,0 \\
2001 & Fev & 3 & 532,0 & 7,8 & 76,0 & 32,9 & 19,7 & 26,3 & 62,0 \\
2001 & Mar & 1 & 401,0 & 76,7 & 80,0 & 29,9 & 19,1 & 24,5 & 48,0 \\
2001 & Mar & 2 & 479,0 & 18,6 & 76,0 & 32,3 & 19,8 & 26,0 & 54,0 \\
2001 & Mar & 3 & 466,0 & 68,9 & 77,0 & 32,2 & 19,2 & 25,7 & 52,0 \\
\hline & & & & & & & & \\
\hline
\end{tabular}

TData da semeadura: 1 de novembro de 2000

${ }^{2}$ Data da colheita: 16 de março de 2001 


\subsection{Implantação e condução do experimento de campo}

\subsubsection{Semeadura e tratos culturais}

O experimento foi instalado em área irrigada por pivô central, em sistema de plantio direto, tendo seu início no dia 24 de outubro de 2000, quando foi efetuada a dessecação das plantas daninhas presentes na área, na qual predominavam o picão preto (Bidens pilosa), o capim carrapicho (Cenchrus echinatus), a trapoeraba (Commelina virginica), a losna branca (Parthenium hysterophorus) e o capim massambará (Sorghum halepense). Para tal, utilizourse o herbicida Glyphosate na dose de 3,0 $\mathrm{Lha}^{-1}$, o qual foi aplicado mediante o uso de um pulverizador de barras regulado para a vazão de 200 L.ha $^{-1}$.

A semeadura foi realizada manualmente no dia 1 de novembro de 2000 , sendo que foram distribuídas nove sementes por metro linear de sulco, o qual foi aberto manualmente através do uso da ferramenta denominada sacho. Cada parcela experimental foi composta por quatro linhas de $5 \mathrm{~m}$ de comprimento, com espaçamento de $0,8 \mathrm{~m}$ entre si, perfazendo área total de $16 \mathrm{~m}^{2}$ e área útil de $6,4 \mathrm{~m}^{2}$, uma vez que as linhas externas foram consideradas bordaduras e que, por ocasião da colheita, descartouse $0,5 \mathrm{~m}$ nas extremidades de cada linha central.

$\mathrm{Na}$ adubação de semeadura foram aplicados, manualmente, no sulco, $80 \mathrm{~kg} \cdot \mathrm{ha}^{-1}$ de $\mathrm{P}_{2} \mathrm{O}_{5}$ e $60 \mathrm{~kg} . h a^{-1}$ de $\mathrm{K}_{2} \mathrm{O}$, mediante o uso de superfosfato simples $\left(18 \% \mathrm{P}_{2} \mathrm{O}_{5}\right)$ e cloreto de potássio $\left(60 \% \mathrm{~K}_{2} \mathrm{O}\right)$, respectivamente. A determinação da dose de tais elementos foi fundamentada nos resultados da análise do solo (Tabela 2), na eficiência das fontes utilizadas e nos valores de exportação desses nutrientes pela cultura de milho (Fancelli \& Dourado Neto, 2000). Ainda, por ocasião da semeadura, efetuourse a adubação nitrogenada com $30 \mathrm{~kg} \cdot \mathrm{ha}^{-1}$ de $\mathrm{N}$, apenas nos tratamentos que incluíam a aplicação do referido elemento, sendo que para tal, aplicou-se uréia $(45 \% \mathrm{~N})$ no sulco, juntamente com os fertilizantes mencionados anteriormente. $O$ restante do nitrogênio, necessário para completar a dose requerida pelos diferentes tratamentos estudados, foi aplicado manualmente, em cobertura, na entrelinha, a uma distância de $25 \mathrm{~cm}$ do colmo, no momento em que as plantas de milho apresentavam 5 folhas plenamente expandidas. 
O híbrido utilizado foi o Cargill 909, tipo simples, ciclo superprecoce, com grão flint e cor laranja, cuja necessidade calórica, para o florescimento, correspondente a 810 graus-dia $\left({ }^{\circ} \mathrm{C} \cdot d^{-1}{ }^{-1}\right)$. Esse híbrido, de acordo com a Empresa produtora, também apresenta como características, altura média de plantas de 2,20 m e altura média de inserção de espiga de $1,20 \mathrm{~m}$, sendo que a população considerada ideal situa-se entre 55.000 e 60.000 plantas por hectare.

Após a emergência das plântulas, quando as plantas de milho apresentavam duas folhas plenamente expandidas, realizoutse o desbaste objetivando assegurar o estande de 4,8 plantas por metro, de forma a perfazer a população de 60.000 plantas por hectare, a qual foi mantida até a colheita.

Cabe salientar que após a semeadura do milho, aplicoutse o herbicida (em préemergência) de ingrediente ativo Atrazine (200 g. $\left.\mathrm{L}^{-1}\right)+$ Metolachlor (300 g. $\left.\mathrm{L}^{-1}\right)$, através

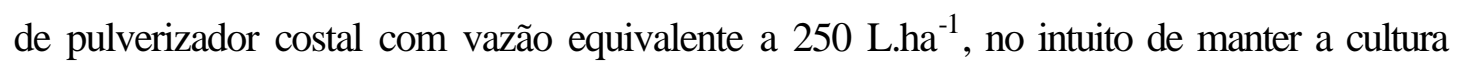
livre da presença de plantas daninhas até a colheita.

Para o controle de lagarta do cartucho (Spodoptera frugiperda), aplicou-se os inseticidas Lufenuron $\left(0,3\right.$ L.ha $\left.^{-1}\right)$ e Lambdacyhalothrin $\left(0,15\right.$ L.ha $\left.^{-1}\right)$, visando evitar a ocorrência de danos provocados pela referida praga.

\subsubsection{Nutrientes avaliados, tratamentos e metodologia de aplicação}

Os nutrientes avaliados no presente experimento foram o nitrogênio, o zinco e o boro (Tabela 4).

O zinco e o boro foram aplicados por ocasião da semeadura, no sulco, juntamente com os demais fertilizantes utilizados (cloreto de potássio e superfosfato simples). Como fonte de tais elementos, utilizou-se o sulfato de zinco (20\% Zn) e o ácido bórico (17\% B), cujos foram aplicados manualmente mediante o uso de recipientes graduados para a dose correspondente a cada tratamento.

O nitrogênio foi aplicado apenas em alguns tratamentos, sendo que nesses, uma parte foi aplicada por ocasião da semeadura $\left(30 \mathrm{~kg} \cdot \mathrm{ha}^{-1}\right)$ e o complemento em cobertura, posicionado na entrelinha, incorporado, a uma distância de $20 \mathrm{~cm}$ do colmo das plantas de milho, no momento em que as plantas apresentavam cinco folhas plenamente 
expandidas. Como fonte de nitrogênio, utilizourse uréia $(45 \% \mathrm{~N})$ a qual foi aplicada manualmente, também mediante o uso de recipientes graduados para a dose correspondente a cada tratamento.

Tabela 4. Descrição sucinta dos tratamentos estudados

\begin{tabular}{|c|c|c|}
\hline \multirow{2}{*}{$\frac{\text { Tratamento }}{1}$} & \multicolumn{2}{|c|}{ Nutrientes e Doses } \\
\hline & Nitrogênio $\left(0 \mathrm{~kg} \cdot \mathrm{ha}^{-1}\right)$ & Testemunha A (sem Zinco e Boro) \\
\hline 2 & Nitrogênio $\left(0 \mathrm{~kg} \cdot \mathrm{ha}^{-1}\right)$ & $2 \mathrm{~kg} \cdot \mathrm{ha}^{-1}$ de Zinco \\
\hline 3 & Nitrogênio $\left(0 \mathrm{~kg} \cdot \mathrm{ha}^{-1}\right)$ & 4 kg.ha ${ }^{-1}$ de Zinco \\
\hline 4 & Nitrogênio $\left(0 \mathrm{~kg} \cdot \mathrm{ha}^{-1}\right)$ & $8 \mathrm{~kg}$ ha $^{-1}$ de Zinco \\
\hline 5 & Nitrogênio $\left(0 \mathrm{~kg} \cdot \mathrm{ha}^{-1}\right)$ & 16 kg.ha ${ }^{-1}$ de Zinco \\
\hline 6 & Nitrogênio $\left(0 \mathrm{~kg} \cdot \mathrm{ha}^{-1}\right)$ & 1 kg.ha ${ }^{-1}$ de Boro \\
\hline 7 & Nitrogênio $\left(0 \mathrm{~kg} \cdot \mathrm{ha}^{-1}\right)$ & 2 kg.ha ${ }^{-1}$ de Boro \\
\hline 8 & Nitrogênio $\left(0 \mathrm{~kg}^{-h^{-1}}\right)$ & 4 kg.ha ${ }^{-1}$ de Boro \\
\hline 9 & Nitrogênio $\left(0 \mathrm{~kg} \cdot \mathrm{ha}^{-1}\right)$ & $8 \mathrm{~kg}^{\mathrm{h}} \mathrm{h}^{-1}$ de Boro \\
\hline 10 & Nitrogênio $\left(120 \mathrm{~kg} \cdot \mathrm{ha}^{-1}\right)$ & Testemunha B (sem Zinco e Boro) \\
\hline 11 & Nitrogênio (120 kg.ha $\left.{ }^{-1}\right)$ & 2 kg.ha ${ }^{-1}$ de Zinco \\
\hline 12 & Nitrogênio (120 kg.ha-1) & 4 kg.ha ${ }^{-1}$ de Zinco \\
\hline 13 & Nitrogênio $\left(120 \mathrm{~kg} \cdot \mathrm{ha}^{-1}\right)$ & $8 \mathrm{~kg} \cdot \mathrm{ha}^{-1}$ de Zinco \\
\hline 14 & Nitrogênio (120 kg.ha $\left.{ }^{-1}\right)$ & 16 kg.ha ${ }^{-1}$ de Zinco \\
\hline 15 & Nitrogênio $\left(120 \mathrm{~kg} \cdot \mathrm{ha}^{-1}\right)$ & 1 kg.ha ${ }^{-1}$ de Boro \\
\hline 16 & Nitrogênio (120 kg.ha-1) & $2 \mathrm{~kg} \mathrm{ha}^{-1}$ de Boro \\
\hline 17 & Nitrogênio $\left(120 \mathrm{~kg} \cdot \mathrm{ha}^{-1}\right)$ & 4 kg.ha ${ }^{-1}$ de Boro \\
\hline 18 & Nitrogênio $\left(120 \mathrm{~kg} \cdot \mathrm{ha}^{-1}\right)$ & $8 \mathrm{~kg} \cdot \mathrm{ha}^{-1}$ de Boro \\
\hline 19 & Nitrogênio $\left(240 \mathrm{~kg} \cdot \mathrm{ha}^{-1}\right)$ & Testemunha C (sem Zinco e Boro) \\
\hline 20 & Nitrogênio $\left(240 \mathrm{~kg} \cdot \mathrm{ha}^{-1}\right)$ & 2 kg.ha ${ }^{-1}$ de Zinco \\
\hline 21 & Nitrogênio $\left(240 \mathrm{~kg} \cdot \mathrm{ha}^{-1}\right)$ & $4 \mathrm{~kg} \mathrm{ha}^{-1}$ de Zinco \\
\hline 22 & Nitrogênio $\left(240 \mathrm{~kg} \cdot \mathrm{ha}^{-1}\right)$ & 8 kg.ha ${ }^{-1}$ de Zinco \\
\hline 23 & Nitrogênio $\left(240 \mathrm{~kg} \cdot \mathrm{ha}^{-1}\right)$ & 16 kg.ha ${ }^{-1}$ de Zinco \\
\hline 24 & Nitrogênio $\left(240 \mathrm{~kg} \cdot \mathrm{ha}^{-1}\right)$ & 1 kg.ha ${ }^{-1}$ de Boro \\
\hline 25 & Nitrogênio $\left(240 \mathrm{~kg} \cdot \mathrm{ha}^{-1}\right)$ & $2 \mathrm{~kg} \mathrm{ha}^{-1}$ de Boro \\
\hline 26 & Nitrogênio $\left(240 \mathrm{~kg} \cdot \mathrm{ha}^{-1}\right)$ & 4 kg.ha ${ }^{-1}$ de Boro \\
\hline 27 & Nitrogênio $\left(240 \mathrm{~kg} \cdot \mathrm{ha}^{-1}\right)$ & $8 \mathrm{~kg} \cdot \mathrm{ha}^{-1}$ de Boro \\
\hline
\end{tabular}


Para possibilitar a incorporação do nitrogênio aplicado em cobertura, efetuou-se a abertura de um sulco com $5 \mathrm{~cm}$ de profundidade, aplicou-se o fertilizante (uréia) manualmente e realizou-se a cobertura com solo. Tal incorporação foi efetuada no intuito de impedir a volatilização da uréia.

\subsection{Avaliações fitotécnicas}

\subsubsection{Fenologia}

A fenologia da cultura de milho foi avaliada utilizando a escala proposta por Fancelli (1986) e Fancelli \& Dourado Neto (1997), a qual contempla diferentes estádios fenológicos ao longo do ciclo da cultura (Tabela 1).

Os estádios de crescimento e desenvolvimento, que ocorrem anteriormente ao aparecimento das espigas, foram identificados mediante a avaliação do número de folhas plenamente expandidas, ou desdobradas, e os estádios posteriores à emissão das espigas foram identificados com base no desenvolvimento e na consistência dos grãos (Fancelli \& Dourado Neto, 1997). O final de um estádio e o início de outro foi determinado quando $50 \%$ das plantas apresentavam as características particulares de cada estádio em questão.

Cabe salientar que, para a avaliação, foram consideradas como folhas plenamente expandidas as que apresentavam a linha de união lâmina-bainha, popularmente conhecida como "colar", facilmente visível.

\subsection{2 Área foliar e índice de área foliar}

A determinação de área foliar da iésima folha $\left(\mathrm{AFi}, \mathrm{cm}^{2}\right)$ foi realizada 20 dias após a emergência (por ocasião da emissão da quarta folha), 41 dias após a emergência, 49 dias após a emergência, e 65 dias após a emergência (por ocasião do florescimento). Nesta, foram avaliadas 2 (duas) plantas por parcela, mediante a retirada e mensuração de todas as folhas plenamente expandidas de cada planta, no seu comprimento $(\mathrm{Ci}, \mathrm{cm})$ e maior largura $(\mathrm{Li}, \mathrm{cm})$. Os dados obtidos foram submetidos à seguinte equação proposta por Francis (1969), qual seja:

$$
A F_{i}=0,75 \cdot C_{i} \cdot L_{i}
$$


Assim, o Índice de Área Foliar (IAF, $\mathrm{m}^{2} \cdot \mathrm{m}^{-2}$ ) foi obtido pela seguinte equação:

$$
I A F=\frac{A F_{i}}{e_{1} \cdot e_{2}}
$$

em que $e_{1}$ e $e_{2}$ se referem ao espaçamento (cm) entre plantas (na linha) e entre linhas de plantas, respectivamente.

\subsubsection{Altura média da base do pendão e altura média de inserção de espiga}

A determinação da altura média das plantas foi efetuada por ocasião do pleno florescimento através da simples medição do comprimento do colmo (da superfície do solo até a base da inflorescência masculina - "pendão") mediante o uso de escala graduada (trena). Foram consideradas duas plantas de cada parcela.

Para medir a altura média de inserção de espiga utilizou-se uma trena (escala graduada) com a qual determinoutse a distância entre a superfície do solo e o ponto de inserção da espiga com o colmo. Nesta avaliação foram consideradas as mesmas plantas utilizadas para a determinação da altura média de plantas.

\subsubsection{Diâmetro médio do colmo}

Para determinar o diâmetro médio do colmo, considerourse o diâmetro do segundo internódio, a partir da base da planta, o qual foi mensurado através do uso de um paquímetro. Vale ressaltar que tal determinação foi efetuada por ocasião do pleno florescimento e que as plantas avaliadas foram as mesmas utilizadas para obtenção da altura média da base do pendão e altura média de inserção de espigas (foram avaliadas duas plantas por parcela).

\subsubsection{Comprimento médio do primeiro e do segundo internódio do colmo}

O comprimento médio dos internódios do colmo foi determinado por ocasião do pleno florescimento através da simples medição com auxílio de escala graduada (trena). Foram consideradas duas plantas de cada parcela, as quais foram utilizadas para a determinação da altura média da base do pendão, altura média de inserção de espiga e diâmetro médio do colmo. 


\subsubsection{Massa média de matéria seca de folha, colmo, pendão e espiga}

A determinação da massa média de matéria seca de folhas, colmo, pendão e espiga foi realizada mediante a retirada (método destrutivo) de duas plantas localizadas na área útil da parcela experimental, nas quais foram efetuadas a separação das diferentes partes (folhas, colmo, pendão e espiga). As partes semelhantes coletadas nas plantas de cada parcela (pendões das duas plantas, por exemplo) foram reunidas e colocadas em sacos de papel. Posteriormente, realizou-se a pesagem (obtenção de peso úmido) de cada parte, as quais foram submetidas a uma pré-secagem natural por 5 dias e, posteriormente, a uma secagem forçada em estufa com temperatura de $75^{\circ} \mathrm{C}$, até atingir massa constante (massa seca). Assim, através da diferença entre a massa úmida e a massa seca do material coletado, obteve-se a fitomassa seca dos diferentes órgãos da planta.

\subsubsection{Componentes de produtividade}

\subsubsection{Prolificidade}

A prolificidade foi determinada através da simples contagem no número total de espigas colhidas na área útil da parcela experimental, sendo que o número obtido foi dividido pelo número de plantas, obtendo-se assim o número médio de espigas por planta.

\subsubsection{Comprimento médio da espiga}

A determinação do comprimento médio das espigas foi realizada após a colheita, separando-se aleatoriamente doze espigas colhidas em cada parcela, as quais foram medidas através do uso de escala graduada (trena).

\subsubsection{Número médio de grãos por fileira da espiga}

O número médio de grãos por fileira da espiga foi determinado mediante simples contagem dos grãos presentes nas fileiras das espigas amostradas aleatoriamente em cada parcela. Para tal, foram avaliadas doze espigas por parcela, sendo essas utilizadas na determinação do comprimento médio de espigas. 


\subsubsection{Numero médio de fileiras de grãos da espiga}

O número médio de fileiras de grãos da espiga foi determinado através de simples contagem. Foram amostradas doze espigas em cada parcela, sendo essas utilizadas na determinação do comprimento médio de espigas e do número médio de grãos por fileira.

\subsubsection{Diâmetro médio da espiga}

O diâmetro médio da espiga foi obtido mediante o uso de um paquímetro, sendo que o ponto considerado na avaliação foi o correspondente ao centro da espiga. Foram amostradas doze espigas em cada parcela, sendo essas utilizadas na determinação do comprimento médio de espigas, do número médio de grãos por fileira e do número médio de fileiras da espiga.

\subsubsection{Diâmetro médio do sabugo}

Após a debulha das espigas utilizadas na determinação do diâmetro médio de espiga (doze espigas), foi determinado o diâmetro do sabugo através do uso de um paquímetro, sendo que o ponto considerado na avaliação foi o correspondente ao centro do sabugo.

\subsubsection{Comprimento médio de grãos}

Para determinar o comprimento médio dos grãos da espiga, considerourse a diferença entre o diâmetro médio da espiga e o diâmetro médio do sabugo.

\subsubsection{Massa de mil grãos}

Após a debulha de todas as espigas colhidas na área útil das parcelas experimentais, determinou-se a massa de mil grãos, de acordo com a metodologia proposta por Brasil (1992), a qual corresponde à média da massa de oito amostras de cem grãos, submetidas à análise de desvio padrão, originadas de cada parcela. Assim, do total de grãos oriundos da debulha, retirou-se oito amostras ao acaso, contendo cem grãos cada, os quais foram submetidos à pesagem e à determinação imediata da umidade, possibilitando estimar a massa de mil grãos corrigida para 13\% de umidade. 
Cabe salientar que o conteúdo de água dos grãos foi obtido mediante o uso de um medidor de conteúdo de água de grãos, portátil, do modelo Multi-grain, marca Jickey John, o qual propicia leitura direta em display digital.

\subsubsection{Produtividade}

A produtividade foi obtida a partir da debulha e pesagem dos grãos oriundos de todas as espigas colhidas na área útil das parcelas experimentais (kg.parcela ${ }^{-1}$ ), a qual foi convertida para $\mathrm{kg} \cdot \mathrm{ha}^{-1}$ e devidamente corrigida para $13 \%$ de umidade.

\subsection{Delineamento experimental}

Os tratamentos constituíram-se de combinações dos fatores doses de nitrogênio, doses de zinco e doses de boro, arranjados no esquema fatorial, totalizando 27 tratamentos (Erro! A origem da referência não foi encontrada.) e três repetições. O delineamento experimental utilizado foi casualizado em blocos.

Foi realizada análise de variância para todas as variáveis de interesse (índice de área foliar, número de folhas fotossinteticamente ativas, altura de planta, altura de inserção da espiga, diâmetro do colmo, comprimento do primeiro e do segundo internódio do colmo, massa de matéria seca de folhas, colmo, pendão e espiga, número de espigas por planta (prolificidade), comprimento da espiga, número de grãos por fileira, número de fileiras de grãos na espiga, comprimento dos grãos, massa de mil grãos e produtividade de grãos) utilizando o procedimento GLM do SAS System (SAS, 1998). Os efeitos de N, B, e $\mathrm{Zn}$ e de suas interações foram avaliados pelo teste F. Quando apenas o efeito de $\mathrm{N}$ foi significativo, foram ajustadas funções de resposta para esse elemento. Para as variáveis onde houve interação entre N e B ou entre $\mathrm{N}$ e Zn, foram ajustados modelos para descrever a variação do fator em questão em função das doses de $\mathrm{B}$ ou de $\mathrm{Zn}$, para cada nível de $\mathrm{N}$, pelo método de máxima verossimilhança, utilizando o procedimento MIXED do SAS (SAS, 1998). Quando não houve interação, mas efeito significativo de $\mathrm{N}$ e $\mathrm{B}$ ou $\mathrm{N}$ e $\mathrm{Zn}$, ajustaram-se superfícies de resposta aos dois elementos considerados em cada caso. 


\section{RESULTADOS E DISCUSSÃO}

\subsection{Síntese dos resultados}

As Tabelas 5, 6, 7, 8 e 9 apresentam os valores médios referentes as variáveis número de folhas fotossinteticamente ativas aos 41, 49 e 65 dias após a emergência das plantas (Tabela 1), índice de área foliar aos 20, 41, 49 e 65 dias após a emergência das plantas (Tabela 2), diâmetro do colmo, massa de matéria seca de folha, colmo, espiga com palha e pendão (Tabela 3), altura da base de pendão, altura de inserção de espiga, prolificidade, comprimento do primeiro e segundo internódios (Tabela 4), número de fileiras de grãos por espiga, número de grãos por fileira, comprimento do grão e da espiga, massa de mil grãos e produtividade (Tabela 5) em função de doses crescentes de nitrogênio, zinco e boro.

As Tabelas 10, 11, 12 e 13 apresentam os valores referentes ao teste $\mathrm{F}$ e as Tabelas 14, 15, 16 e 17 apresentam os coeficiente de correlação de Pearson para as mesmas variáveis citadas anteriormente.

A Tabela 18 apresenta as estimativas dos parâmetros do modelo de regressão polinomial quadrático, com os respectivos valores de erro padrão, que descrevem a relação entre as variáveis altura da base do pendão (ABP), altura de inserção de espigas (AIE), altura do segundo internódio do colmo (ALT_NO2), comprimento da espiga (COMPESP), diâmetro do colmo (DC), índice de área foliar ao 49 (IAF3) e 65 dias (IAF4), produtividade (PROD) e prolificidade (PROLIF), e as doses de nitrogênio aplicadas.

A Tabela 19 apresenta as estimativas dos parâmetros dos modelos de regressão polinomial quadrática, com os respectivos valores de erro padrão, que descrevem a relação entre as variáveis número de grãos por fileira (NGF) e índice de área foliar aos 
41 dias após a emergência (IAF2) e as doses de boro em cada dose de nitrogênio.

A Tabela 20 apresenta as estimativas dos parâmetros dos modelos de regressão polinomial quadrática, com os respectivos valores de erro padrão, que descrevem a relação entre as variáveis número de folhas fotossinteticamente ativas aos 65 dias após a emergência (NF4) e massa de mil grãos (M1000G), e as doses de zinco em cada dose de nitrogênio. 


\subsubsection{Valores médios referentes às variáveis estudadas}

Tabela 1. Valores médios de número de folhas por planta aos 20 (NF1), 41 (NF2), 49 (NF3) e 65 (NF4) dias após a emergência em função das doses $\left(\mathrm{kg} \cdot \mathrm{ha}^{-1}\right)$ de nitrogênio (DN), zinco (DZn) e boro (DB)

\begin{tabular}{ccccccc}
\hline DN & DZn & DB & NF1 & NF2 & NF3 & NF4 \\
\hline 0 & 0 & 0 & 4,00 & 6,16 & 11,50 & 17,83 \\
0 & 0 & 1 & 4,00 & 6,50 & 12,00 & 18,16 \\
0 & 0 & 2 & 4,00 & 6,16 & 11,66 & 17,66 \\
0 & 0 & 4 & 4,00 & 6,50 & 12,66 & 18,00 \\
0 & 0 & 8 & 4,00 & 6,66 & 12,00 & 18,33 \\
0 & 2 & 0 & 4,00 & 6,50 & 12,16 & 18,00 \\
0 & 4 & 0 & 4,00 & 6,50 & 12,50 & 18,00 \\
0 & 8 & 0 & 4,00 & 6,33 & 11,66 & 18,16 \\
0 & 16 & 0 & 4,00 & 6,66 & 12,33 & 17,83 \\
120 & 0 & 0 & 4,00 & 8,16 & 14,16 & 18,00 \\
120 & 0 & 1 & 4,00 & 7,33 & 13,00 & 18,83 \\
120 & 0 & 2 & 4,00 & 8,33 & 14,00 & 19,00 \\
120 & 0 & 4 & 4,00 & 8,16 & 14,16 & 19,33 \\
120 & 0 & 8 & 4,00 & 8,16 & 14,50 & 19,00 \\
120 & 2 & 0 & 4,00 & 7,83 & 14,33 & 18,83 \\
120 & 4 & 0 & 4,00 & 7,50 & 14,16 & 18,83 \\
120 & 8 & 0 & 4,00 & 7,66 & 14,16 & 19,00 \\
120 & 16 & 0 & 4,00 & 8,50 & 13,83 & 18,83 \\
240 & 0 & 0 & 4,00 & 8,33 & 14,66 & 19,83 \\
240 & 0 & 1 & 4,00 & 7,83 & 13,66 & 19,50 \\
240 & 0 & 2 & 4,00 & 8,33 & 14,33 & 19,00 \\
240 & 0 & 4 & 4,00 & 7,83 & 14,66 & 19,33 \\
240 & 0 & 8 & 4,00 & 8,00 & 14,16 & 19,33 \\
240 & 2 & 0 & 4,00 & 8,66 & 14,33 & 18,66 \\
240 & 4 & 0 & 4,00 & 8,00 & 13,50 & 18,83 \\
240 & 8 & 0 & 4,00 & 7,00 & 13,33 & 19,83 \\
240 & 16 & 0 & 4,00 & 7,66 & 13,66 & 19,33 \\
\hline NF4 corresponde àavaliacão efetuada por ocasião 0 do florescimento & &
\end{tabular}

${ }^{1}$ NF4 corresponde à avaliação efetuada por ocasião do florescimento 
Tabela 2. Valores médios de índice de área foliar $\left(\mathrm{m}^{2} \cdot \mathrm{m}^{-2}\right)$ aos 20 (IAF1), 41 (IAF2), 49 (IAF3) e 65 (IAF4) dias após a emergência em função das doses $\left(\mathrm{kg} \cdot \mathrm{ha}^{-1}\right)$ de nitrogênio (DN), zinco (DZn) e boro (DB)

\begin{tabular}{ccccccc}
\hline DN & DZn & DB & IAF1 & IAF2 & IAF3 & IAF4 ${ }^{1}$ \\
\hline 0 & 0 & 0 & 0,09 & 0,97 & 1,96 & 2,44 \\
0 & 0 & 1 & 0,09 & 0,98 & 2,08 & 2,43 \\
0 & 0 & 2 & 0,10 & 1,30 & 2,65 & 2,83 \\
0 & 0 & 4 & 0,10 & 0,95 & 1,91 & 2,27 \\
0 & 0 & 8 & 0,09 & 1,19 & 2,39 & 2,93 \\
0 & 2 & 0 & 0,09 & 1,10 & 2,08 & 2,67 \\
0 & 4 & 0 & 0,10 & 1,04 & 2,11 & 2,70 \\
0 & 8 & 0 & 0,11 & 1,18 & 2,44 & 2,69 \\
0 & 16 & 0 & 0,10 & 1,04 & 2,21 & 2,73 \\
120 & 0 & 0 & 0,11 & 1,59 & 3,18 & 3,55 \\
120 & 0 & 1 & 0,11 & 1,77 & 3,32 & 3,83 \\
120 & 0 & 2 & 0,12 & 1,35 & 2,91 & 3,75 \\
120 & 0 & 4 & 0,11 & 1,57 & 3,08 & 4,46 \\
120 & 0 & 8 & 0,11 & 1,68 & 3,16 & 4,10 \\
120 & 2 & 0 & 0,12 & 1,51 & 3,15 & 4,08 \\
120 & 4 & 0 & 0,10 & 1,56 & 3,18 & 3,90 \\
120 & 8 & 0 & 0,12 & 1,70 & 3,75 & 4,23 \\
120 & 16 & 0 & 0,11 & 1,68 & 3,47 & 3,92 \\
240 & 0 & 0 & 0,11 & 2,02 & 3,94 & 4,79 \\
240 & 0 & 1 & 0,10 & 1,44 & 3,27 & 4,26 \\
240 & 0 & 2 & 0,10 & 1,55 & 3,13 & 4,25 \\
240 & 0 & 4 & 0,11 & 1,34 & 3,11 & 4,34 \\
240 & 0 & 8 & 0,10 & 1,41 & 3,23 & 4,36 \\
240 & 2 & 0 & 0,11 & 1,51 & 3,09 & 4,04 \\
240 & 4 & 0 & 0,11 & 1,65 & 3,40 & 4,38 \\
240 & 8 & 0 & 0,10 & 1,97 & 3,59 & 4,17 \\
240 & 16 & 0 & 0,11 & 1,74 & 3,46 & 4,45 \\
\hline $1 A F 4$ & 0 & 0 & 11 & &
\end{tabular}

' IAF4 corresponde à avaliação efetuada por ocasião do florescimento 
Tabela 3. Valores médios de diâmetro do colmo (DC, $\mathrm{cm}$ ), massa de matéria seca de folha (MMSF, g.planta ${ }^{-1}$ ), colmo (MMSC, g.planta ${ }^{-1}$ ), espiga com palha (MMSE, g.espiga ${ }^{-1}$ ) e pendão (MMSP, g.planta ${ }^{-1}$ ), em função das doses $\left(\mathrm{kg}_{\mathrm{h}} \mathrm{ha}^{-1}\right)$ de nitrogênio (DN), zinco (DZn) e boro (DB)

\begin{tabular}{cccccccc}
\hline DN & DZn & DB & DC & MMSF & MMSC & MMSE & MMSP \\
\hline 0 & 0 & 0 & 1,85 & 72,49 & 68,81 & 190,08 & 6,23 \\
0 & 0 & 1 & 1,96 & 84,60 & 86,56 & 125,75 & 7,92 \\
0 & 0 & 2 & 1,86 & 74,86 & 73,35 & 160,96 & 6,86 \\
0 & 0 & 4 & 1,93 & 82,69 & 103,86 & 178,52 & 7,88 \\
0 & 0 & 8 & 1,91 & 88,72 & 95,55 & 214,50 & 6,93 \\
0 & 2 & 0 & 1,75 & 62,66 & 63,34 & 194,05 & 5,73 \\
0 & 4 & 0 & 1,95 & 89,72 & 92,60 & 160,67 & 6,68 \\
0 & 8 & 0 & 1,87 & 81,32 & 86,79 & 134,36 & 7,96 \\
0 & 16 & 0 & 1,95 & 77,56 & 82,87 & 167,24 & 7,22 \\
120 & 0 & 0 & 2,28 & 95,05 & 114,82 & 191,71 & 9,15 \\
120 & 0 & 1 & 2,17 & 97,42 & 132,47 & 271,73 & 8,16 \\
120 & 0 & 2 & 2,10 & 101,52 & 128,06 & 288,62 & 7,36 \\
120 & 0 & 4 & 2,18 & 108,03 & 118,10 & 246,42 & 9,26 \\
120 & 0 & 8 & 2,40 & 101,21 & 128,39 & 286,50 & 9,18 \\
120 & 2 & 0 & 2,25 & 99,66 & 127,09 & 283,22 & 9,59 \\
120 & 4 & 0 & 2,20 & 118,91 & 172,97 & 250,77 & 9,77 \\
120 & 8 & 0 & 2,37 & 97,09 & 127,68 & 238,96 & 7,62 \\
120 & 16 & 0 & 2,32 & 118,39 & 137,13 & 283,13 & 8,98 \\
240 & 0 & 0 & 2,39 & 106,94 & 125,84 & 303,15 & 8,13 \\
240 & 0 & 1 & 2,27 & 105,00 & 138,88 & 289,81 & 9,02 \\
240 & 0 & 2 & 2,28 & 119,58 & 141,10 & 291,03 & 7,98 \\
240 & 0 & 4 & 2,21 & 105,59 & 122,54 & 281,79 & 8,97 \\
240 & 0 & 8 & 2,25 & 111,00 & 133,80 & 302,73 & 8,84 \\
240 & 2 & 0 & 2,25 & 103,07 & 126,84 & 279,43 & 8,79 \\
240 & 4 & 0 & 2,30 & 106,97 & 143,98 & 292,52 & 9,96 \\
240 & 8 & 0 & 2,26 & 124,02 & 151,29 & 264,24 & 9,03 \\
240 & 16 & 0 & 2,38 & 131,24 & 124,92 & 271,98 & 9,32 \\
\hline & & & & & & & \\
\hline
\end{tabular}


Tabela 4. Valores médios de altura da base de pendão (ABP, m), altura de inserção de espiga (AIE, m), prolificidade (PROLIF, espiga.planta ${ }^{-1}$ ), comprimento do primeiro (COMP_NO1, cm) e segundo (COMP_NO2, cm) internódios em função das doses $\left(\mathrm{kg} \cdot \mathrm{ha}^{-1}\right)$ de nitrogênio (DN), zinco (DZn) e boro (DB)

\begin{tabular}{cccccccc}
\hline DN & DZn & DB & ABP & AIE & PROLIF & COMP_NO1 & COMP_NO2 \\
\hline 0 & 0 & 0 & 1,82 & 0,88 & 1,16 & 2,83 & 7,08 \\
0 & 0 & 1 & 1,85 & 0,83 & 1,02 & 2,75 & 6,80 \\
0 & 0 & 2 & 1,88 & 0,91 & 1,11 & 3,08 & 6,91 \\
0 & 0 & 4 & 1,78 & 0,85 & 1,08 & 2,86 & 6,91 \\
0 & 0 & 8 & 1,98 & 0,85 & 1,13 & 2,96 & 7,15 \\
0 & 2 & 0 & 1,91 & 0,89 & 1,06 & 2,58 & 6,58 \\
0 & 4 & 0 & 1,86 & 0,91 & 0,96 & 3,55 & 8,08 \\
0 & 8 & 0 & 1,84 & 0,85 & 1,07 & 3,13 & 6,50 \\
0 & 16 & 0 & 1,85 & 0,91 & 1,06 & 3,33 & 7,00 \\
120 & 0 & 0 & 2,17 & 1,11 & 1,22 & 3,55 & 9,00 \\
120 & 0 & 1 & 2,23 & 1,16 & 1,30 & 3,50 & 8,50 \\
120 & 0 & 2 & 2,17 & 1,14 & 1,21 & 3,90 & 8,58 \\
120 & 0 & 4 & 2,13 & 1,14 & 1,22 & 3,41 & 8,25 \\
120 & 0 & 8 & 2,11 & 1,13 & 1,28 & 4,00 & 9,00 \\
120 & 2 & 0 & 2,19 & 1,15 & 1,46 & 3,58 & 8,83 \\
120 & 4 & 0 & 2,19 & 1,17 & 1,29 & 3,11 & 8,66 \\
120 & 8 & 0 & 2,26 & 1,16 & 1,28 & 3,66 & 9,25 \\
120 & 16 & 0 & 2,12 & 1,12 & 1,37 & 4,83 & 9,58 \\
240 & 0 & 0 & 2,28 & 1,20 & 1,36 & 5,00 & 9,66 \\
240 & 0 & 1 & 2,29 & 1,18 & 1,32 & 3,58 & 9,25 \\
240 & 0 & 2 & 2,25 & 1,17 & 1,35 & 5,25 & 9,91 \\
240 & 0 & 4 & 2,22 & 1,13 & 1,23 & 4,08 & 9,75 \\
240 & 0 & 8 & 2,26 & 1,21 & 1,23 & 5,16 & 10,41 \\
240 & 2 & 0 & 2,16 & 1,16 & 1,28 & 3,75 & 9,16 \\
240 & 4 & 0 & 2,24 & 1,12 & 1,29 & 3,75 & 8,41 \\
240 & 8 & 0 & 2,29 & 1,18 & 1,29 & 4,66 & 9,25 \\
240 & 16 & 0 & 2,24 & 1,23 & 1,31 & 4,41 & 9,25 \\
\hline & & & & & & & \\
\hline
\end{tabular}


Tabela 5. Valores médios de número de fileiras de grãos por espiga (NFG), número de grãos por fileira (NGF), comprimento do grão (COMPGRAO, cm) e da espiga (COMPESP, cm), massa de mil grãos (M1000G, g) e produtividade (PROD, kg.ha ${ }^{-1}$ ) em função das doses $\left(\mathrm{kg} \cdot \mathrm{ha}^{-1}\right)$ de nitrogênio (DN), zinco (DZn) e boro (DB)

\begin{tabular}{ccccccccc}
\hline DN & DZn & DB & NFG & NGF & COMPGRAO & COMPESP & M1000G & PROD \\
\hline 0 & 0 & 0 & 14,05 & 29,58 & 1,16 & 14,86 & 207,96 & 3759,28 \\
0 & 0 & 1 & 14,16 & 30,05 & 1,25 & 14,80 & 225,05 & 4464,92 \\
0 & 0 & 2 & 14,33 & 26,47 & 1,39 & 15,00 & 226,99 & 4790,41 \\
0 & 0 & 4 & 14,05 & 29,41 & 1,22 & 13,77 & 212,94 & 3245,03 \\
0 & 0 & 8 & 14,22 & 37,83 & 1,18 & 14,66 & 212,31 & 4587,82 \\
0 & 2 & 0 & 13,66 & 28,11 & 1,30 & 14,25 & 233,98 & 4408,59 \\
0 & 4 & 0 & 14,16 & 28,72 & 1,26 & 14,75 & 220,80 & 4004,13 \\
0 & 8 & 0 & 14,22 & 28,78 & 1,28 & 14,58 & 238,14 & 5205,82 \\
0 & 16 & 0 & 14,16 & 29,47 & 1,32 & 15,28 & 238,49 & 4726,59 \\
120 & 0 & 0 & 14,05 & 36,97 & 1,39 & 17,91 & 234,56 & 8199,95 \\
120 & 0 & 1 & 14,22 & 34,83 & 1,34 & 18,08 & 234,88 & 8494,91 \\
120 & 0 & 2 & 14,55 & 35,77 & 1,40 & 17,16 & 245,02 & 8467,79 \\
120 & 0 & 4 & 13,89 & 37,27 & 1,42 & 18,00 & 253,36 & 7499,04 \\
120 & 0 & 8 & 14,50 & 39,11 & 1,44 & 17,86 & 234,33 & 8701,81 \\
120 & 2 & 0 & 14,66 & 37,86 & 1,36 & 17,77 & 225,53 & 8565,20 \\
120 & 4 & 0 & 14,55 & 37,44 & 1,51 & 18,30 & 251,79 & 8531,97 \\
120 & 8 & 0 & 14,28 & 37,89 & 1,34 & 18,13 & 234,19 & 8700,67 \\
120 & 16 & 0 & 14,11 & 38,11 & 1,33 & 17,97 & 220,36 & 8256,89 \\
240 & 0 & 0 & 14,55 & 38,41 & 1,46 & 18,58 & 246,96 & 9789,33 \\
240 & 0 & 1 & 14,39 & 38,44 & 1,42 & 18,75 & 235,52 & 9411,82 \\
240 & 0 & 2 & 14,55 & 39,11 & 1,54 & 18,89 & 258,04 & 9293,04 \\
240 & 0 & 4 & 14,11 & 38,25 & 1,44 & 18,19 & 241,04 & 8200,67 \\
240 & 0 & 8 & 14,27 & 30,80 & 1,41 & 18,11 & 243,18 & 8720,67 \\
240 & 2 & 0 & 14,22 & 38,33 & 1,37 & 18,80 & 253,38 & 8595,31 \\
240 & 4 & 0 & 14,44 & 37,38 & 1,41 & 18,41 & 240,07 & 9060,89 \\
240 & 8 & 0 & 14,11 & 38,77 & 1,40 & 17,86 & 232,72 & 8486,35 \\
240 & 16 & 0 & 14,72 & 37,94 & 1,46 & 18,50 & 252,02 & 9601,77 \\
\hline & & & & & & & & \\
\end{tabular}




\subsubsection{Resultados das análises de variância}

Tabela 6. Resultado dos testes $\mathrm{F}$ para avaliar o efeito das doses de nitrogênio $\left(\mathrm{DN}, \mathrm{kg} \cdot \mathrm{ha}^{-1}\right)$, boro (DB, kg.ha- $\left.{ }^{-1}\right)$ e zinco $\left(\mathrm{DZn}, \mathrm{kg}^{\mathrm{h}} \mathrm{ha}^{-1}\right)$ e suas interações, sobre variáveis altura de inserção de espiga (AIE), comprimento do primeiro (COMP_NO1) e do segundo (COMP_NO2) internódios, comprimento da espiga (COMPESP) e do grão (COMPGRAO)

\begin{tabular}{|c|c|c|c|c|}
\hline Variável & Fonte & $\mathrm{GL}^{1}$ & $\mathrm{~F}^{2}$ & $\mathrm{PROB}^{3}$ \\
\hline AIE & Bloco & 2 & 5,89090 & 0,00494 \\
\hline AIE & $\mathrm{DN}$ & 2 & 11,76780 & 0,00006 \\
\hline AIE & DZn & 4 & 0,08630 & 0,98633 \\
\hline AIE & DB & 4 & 0,13030 & 0,97068 \\
\hline AIE & DNxDZn & 8 & 0,35700 & 0,93821 \\
\hline AIE & DNxDB & 8 & 0,27920 & 0,96998 \\
\hline COMP_NO1 & Bloco & 2 & 1,89200 & 0,16100 \\
\hline COMP_NO1 & DN & 2 & 1,10050 & 0,34034 \\
\hline COMP_NO1 & DZn & 4 & 1,41270 & 0,24277 \\
\hline COMP_NO1 & DB & 4 & 1,50080 & 0,21551 \\
\hline COMP_NO1 & DNxDZn & 8 & 1,02460 & 0,42970 \\
\hline COMP_NO1 & DNxDB & 8 & 0,50980 & 0,84356 \\
\hline COMP_NO2 & Bloco & 2 & 4,14640 & 0,02134 \\
\hline COMP_NO2 & DN & 2 & 5,02410 & 0,01012 \\
\hline COMP_NO2 & DZn & 4 & 0,20910 & 0,93225 \\
\hline COMP_NO2 & DB & 4 & 0,46110 & 0,76391 \\
\hline COMP_NO2 & DNxDZn & 8 & 0,73050 & 0,66405 \\
\hline COMP_NO2 & DNxDB & 8 & 0,11840 & 0,99830 \\
\hline COMPESP & Bloco & 2 & 11,04120 & 0,00010 \\
\hline COMPESP & DN & 2 & 16,00590 & $\leq 0,00001$ \\
\hline COMPESP & DZn & 4 & 0,19000 & 0,94255 \\
\hline COMPESP & DB & 4 & 0,34980 & 0,84299 \\
\hline COMPESP & DNxDZn & 8 & 0,28250 & 0,96887 \\
\hline COMPESP & DNxDB & 8 & 0,42530 & 0,90056 \\
\hline COMPGRAO & Bloco & 2 & 9,31530 & 0,00035 \\
\hline COMPGRAO & $\mathrm{DN}$ & 2 & 0,52490 & 0,59470 \\
\hline COMPGRAO & DZn & 4 & 0,40920 & 0,80120 \\
\hline COMPGRAO & DB & 4 & 1,35570 & 0,26205 \\
\hline COMPGRAO & DNxDZn & 8 & 0,98560 & 0,45795 \\
\hline COMPGRAO & DNxDB & 8 & 0,66280 & 0,72143 \\
\hline
\end{tabular}

Graus de liberdade

${ }^{2}$ Valor F

${ }^{3}$ Probabilidade 
Tabela 7. Resultado dos testes F para avaliar o efeito das doses de nitrogênio $\left(\mathrm{DN}, \mathrm{kg} \cdot \mathrm{ha}^{-1}\right)$, boro (DB, kg.ha $\left.{ }^{-1}\right)$ e zinco (DZn, kg.ha $\left.{ }^{-1}\right)$ e suas interações, sobre variáveis altura da base de pendão (ABP), índice de área foliar determinado aos 20 (IAF1), 41 (IAF2), 49 (IAF3) e 65 (IAF4) dias após a emergência e diâmetro do colmo (DC)

\begin{tabular}{ccccc}
\hline Variável & Fonte & $\mathrm{GL}^{2}$ & $\mathrm{~F}^{2}$ & PROB \\
\hline ABP & Bloco & 2 & 11,58310 & 0,00007 \\
ABP & DN & 2 & 8,13300 & 0,00084 \\
ABP & DZn & 4 & 0,23570 & 0,91698 \\
ABP & DB & 4 & 0,51280 & 0,72659 \\
ABP & DNxDZn & 8 & 0,46670 & 0,87392 \\
ABP & DNxDB & 8 & 0,47210 & 0,87022 \\
IAF1 & Bloco & 2 & 0,10670 & 0,89900 \\
IAF1 & DN & 2 & 0,64600 & 0,52827 \\
IAF1 & DZn & 4 & 0,61820 & 0,65155 \\
IAF1 & DB & 4 & 0,40210 & 0,80625 \\
IAF1 & DNxDZn & 8 & 0,75320 & 0,64475 \\
IAF1 & DNxDB & 8 & 0,20410 & 0,98890 \\
IAF2 & Bloco & 2 & 11,09780 & 0,00010 \\
IAF2 & DN & 2 & 3,40060 & 0,04093 \\
IAF2 & DZn & 4 & 1,24410 & 0,30386 \\
IAF2 & DB & 4 & 1,00980 & 0,41095 \\
IAF2 & DNxDZn & 8 & 0,74160 & 0,65460 \\
IAF2 & DNxDB & 8 & 2,38930 & 0,02830 \\
IAF3 & Bloco & 2 & 18,28070 & $\leq 0,00001$ \\
IAF3 & DN & 2 & 5,76990 & 0,00546 \\
IAF3 & DZn & 4 & 1,93800 & 0,11795 \\
IAF3 & DB & 4 & 0,83090 & 0,51168 \\
IAF3 & DNxDZn & 8 & 0,93840 & 0,49348 \\
IAF3 & DNxDB & 8 & 1,93020 & 0,07494 \\
IAF4 & Bloco & 2 & 2,88790 & 0,06467 \\
IAF4 & DN & 2 & 17,63600 & $\leq 0,00001$ \\
IAF4 & DZn & 4 & 0,15610 & 0,95938 \\
IAF4 & DB & 4 & 0,67000 & 0,61577 \\
IAF4 & DNxDZn & 8 & 1,41250 & 0,21350 \\
IAF4 & DNxDB & 8 & 2,02780 & 0,06106 \\
DC & Bloco & 2 & 2,52630 & 0,08973 \\
DC & DN & 2 & 5,75420 & 0,00553 \\
DC & DZn & 4 & 0,97350 & 0,43005 \\
DC & DB & 4 & 0,85700 & 0,49595 \\
DC & DNxDZn & 8 & 0,54450 & 0,81745 \\
DC & DNxDB & 8 & 1,01770 & 0,43464 \\
\hline
\end{tabular}

Traus de liberdade

${ }^{2}$ Valor $\mathrm{F}$

${ }^{3}$ Probabilidade 
Tabela 8. Resultado dos testes $\mathrm{F}$ para avaliar o efeito das doses de nitrogênio

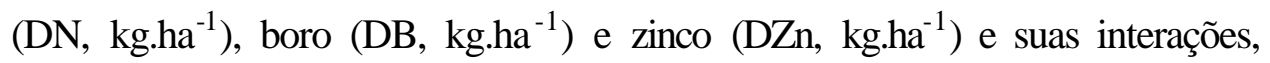
sobre variáveis número de fileiras de grãos por espiga (NFG), número de folhas fotossinteticamente ativas determinado aos 41 (NF2), 49 (NF3) e 65 (NF4) DAE, número de grãos por fileira (NGF) e prolificidade (PROLIF)

\begin{tabular}{|c|c|c|c|c|}
\hline Variável & Fonte & GL & $\mathrm{F}^{2}$ & $\mathrm{PROB}^{3}$ \\
\hline NFG & Bloco & 2 & 1,75570 & 0,18287 \\
\hline NFG & DN & 2 & 0,84090 & 0,43709 \\
\hline NFG & DZn & 4 & 0,38770 & 0,81646 \\
\hline NFG & DB & 4 & 1,36090 & 0,26024 \\
\hline NFG & DNxDZn & 8 & 1,29710 & 0,26568 \\
\hline NFG & DNxDB & 8 & 0,36850 & 0,93248 \\
\hline $\mathrm{NF} 2$ & Bloco & 2 & 5,46000 & 0,00700 \\
\hline NF2 & DN & 2 & 4,26000 & 0,01930 \\
\hline NF2 & DZn & 4 & 0,59000 & 0,66830 \\
\hline NF2 & DB & 4 & 1,69000 & 0,16590 \\
\hline NF2 & DNxDZn & 8 & 0,73000 & 0,66390 \\
\hline NF2 & DNxDB & 8 & 1,45000 & 0,19830 \\
\hline NF3 & Bloco & 2 & 20,71000 & $\leq 0,00010$ \\
\hline NF3 & DN & 2 & 4,78000 & 0,01240 \\
\hline NF3 & DZn & 4 & 2,13000 & 0,08960 \\
\hline NF3 & DB & 4 & 0,76000 & 0,55650 \\
\hline NF3 & DNxDZn & 8 & 1,00000 & 0,44440 \\
\hline NF3 & DNxDB & 8 & 1,25000 & 0,29190 \\
\hline NF4 & Bloco & 2 & 0,54190 & 0,58487 \\
\hline NF4 & DN & 2 & 8,83400 & 0,00050 \\
\hline NF4 & DZn & 4 & 1,49720 & 0,21656 \\
\hline NF4 & DB & 4 & 1,11160 & 0,36106 \\
\hline NF4 & DNxDZn & 8 & 2,16080 & 0,04608 \\
\hline NF4 & DNxDB & 8 & 1,96230 & 0,07007 \\
\hline NGF & Bloco & 2 & 10,64730 & 0,00013 \\
\hline NGF & DN & 2 & 8,55550 & 0,00061 \\
\hline NGF & DZn & 4 & 0,07930 & 0,98834 \\
\hline NGF & DB & 4 & 0,63590 & 0,63921 \\
\hline NGF & DNxDZn & 8 & 0,10610 & 0,99885 \\
\hline NGF & DNxDB & 8 & 5,31410 & 0,00007 \\
\hline PROLIF & Bloco & 2 & 3,94640 & 0,02537 \\
\hline PROLIF & DN & 2 & 12,57470 & 0,00004 \\
\hline PROLIF & DZn & 4 & 0,99980 & 0,41612 \\
\hline PROLIF & DB & 4 & 0,52660 & 0,71663 \\
\hline PROLIF & DNxDZn & 8 & 1,48550 & 0,18527 \\
\hline PROLIF & DNxDB & 8 & 0,87880 & 0,54046 \\
\hline
\end{tabular}


Tabela 9. Resultado dos testes F para avaliar o efeito das doses de nitrogênio $\left(\mathrm{DN}, \mathrm{kg} \cdot \mathrm{ha}^{-1}\right)$, boro (DB, kg.ha $\left.{ }^{-1}\right)$ e zinco (DZn, kg.ha $\left.{ }^{-1}\right)$ e suas interações, sobre variáveis massa de mil grãos (M1000G), produtividade (PROD), massa de matéria seca de colmo (MMSC), folha (MMSF), pendão (MMSP) e espiga (MMSE)

\begin{tabular}{|c|c|c|c|c|}
\hline Variável & Fonte & GL & $\mathrm{F}^{2}$ & $\mathrm{PROB}^{3}$ \\
\hline M1000G & Bloco & 2 & 5,79420 & 0,00535 \\
\hline M1000G & DN & 2 & 0,16430 & 0,84890 \\
\hline M1000G & DZn & 4 & 0,38570 & 0,81789 \\
\hline M1000G & DB & 4 & 1,15270 & 0,34240 \\
\hline M1000G & DNxDZn & 8 & 2,14590 & 0,04755 \\
\hline M1000G & DNxDB & 8 & 0,70010 & 0,68984 \\
\hline PROD & Bloco & 2 & 7,76170 & 0,00112 \\
\hline PROD & DN & 2 & 14,50530 & $<0,00001$ \\
\hline PROD & DZn & 4 & 0,16930 & $\overline{0}, 95310$ \\
\hline PROD & DB & 4 & 1,62830 & 0,18110 \\
\hline PROD & DNxDZn & 8 & 0,71800 & 0,67466 \\
\hline PROD & DNxDB & 8 & 0,33710 & 0,94750 \\
\hline MMSC & Bloco & 2 & 6,39950 & 0,00328 \\
\hline MMSC & DN & 2 & 10,07530 & 0,00020 \\
\hline MMSC & DZn & 4 & 4,90190 & 0,00198 \\
\hline MMSC & DB & 4 & 1,17440 & 0,33288 \\
\hline MMSC & DNxDZn & 8 & 1,11960 & 0,36585 \\
\hline MMSC & DNxDB & 8 & 0,93370 & 0,49711 \\
\hline MMSF & Bloco & 2 & 19,07290 & $<0,00001$ \\
\hline MMSF & DN & 2 & 7,98620 & $\overline{0}, 00095$ \\
\hline MMSF & DZn & 4 & 4,28270 & 0,00453 \\
\hline MMSF & DB & 4 & 0,67510 & 0,61225 \\
\hline MMSF & DNxDZn & 8 & 1,49570 & 0,18158 \\
\hline MMSF & DNxDB & 8 & 0,64740 & 0,73430 \\
\hline MMSP & Bloco & 2 & 2,17970 & 0,12329 \\
\hline MMSP & DN & 2 & 1,74530 & 0,18467 \\
\hline MMSP & DZn & 4 & 0,63260 & 0,64146 \\
\hline MMSP & DB & 4 & 1,12810 & 0,35344 \\
\hline MMSP & DNxDZn & 8 & 1,06940 & 0,39867 \\
\hline MMSP & DNxDB & 8 & 0,50150 & 0,84953 \\
\hline MMSE & Bloco & 2 & 4,85000 & 0,01170 \\
\hline MMSE & DN & 2 & 9,99000 & 0,00020 \\
\hline MMSE & DZn & 4 & 0,79000 & 0,53810 \\
\hline MMSE & DB & 4 & 0,63000 & 0,64240 \\
\hline MMSE & DNxDZn & 8 & 0,96000 & 0,47820 \\
\hline MMSE & DNxDB & 8 & 0,78000 & 0,62600 \\
\hline
\end{tabular}




\subsubsection{Análise de correlação linear}

Tabela 10. Coeficiente de correlação de Pearson $(n=81)$ entre as variáveis analisadas e nível de significância (entre parêntesis) associado ao teste $t$

\begin{tabular}{|c|c|c|c|c|c|c|c|c|}
\hline Variável $^{1}$ & PROD & $\overline{\text { IAF1 }}$ & IAF2 & IAF3 & IAF4 & NF2 & NF3 & NF4 \\
\hline \multirow[t]{2}{*}{ PROD } & 1,0000 & 0,3718 & 0,7054 & 0,8183 & 0,8607 & 0,7607 & 0,7794 & 0,6286 \\
\hline & $(0,0000)$ & $(0,0006)$ & $(\leq 0,0001)$ & $(\leq 0,0001)$ & $(\leq 0,0001)$ & $(\leq 0,0001)$ & $(\leq 0,0001)$ & $(<0,0001)$ \\
\hline \multirow[t]{2}{*}{ IAF1 } & 0,3718 & 1,0000 & $\overline{0}, 2845$ & $\overline{0}, 2869$ & 0,3529 & 0,2759 & 0,2734 & 0,2206 \\
\hline & $(0,0006)$ & $(0,0000)$ & $(0,0100)$ & $(0,0094)$ & $(0,0012)$ & $(0,0127)$ & $(0,0135)$ & $(0,0478)$ \\
\hline \multirow[t]{2}{*}{ IAF2 } & 0,7054 & 0,2845 & 1,0000 & 0,8909 & 0,7337 & 0,8247 & 0,8390 & 0,5763 \\
\hline & $(\leq 0,0001)$ & $(0,0100)$ & $(0,0000)$ & $(\leq 0,0001)$ & $(\leq 0,0001)$ & $(\leq 0,0001)$ & $(<0,0001)$ & $(<0,0001)$ \\
\hline \multirow[t]{2}{*}{ IAF3 } & $\overline{0}, 8183$ & 0,2869 & 0,8909 & 1,0000 & $\overline{0}, 8480$ & 0,7861 & $\overline{0}, 9074$ & 0,6440 \\
\hline & $(\leq 0,0001)$ & $(0,0094)$ & $(\leq 0,0001)$ & $(0,0000)$ & $(\leq 0,0001)$ & $(\leq 0,0001)$ & $(<0,0001)$ & $(<0,0001)$ \\
\hline \multirow[t]{2}{*}{ IAF4 } & $\overline{0}, 8607$ & 0,3529 & 0,7337 & 0,8480 & $\overline{1}, 0000$ & 0,7154 & $\overline{0}, 7725$ & $\overline{0,7755}$ \\
\hline & $(<0,0001)$ & $(0,0012)$ & $(<0,0001)$ & $(<0,0001)$ & $(0,0000)$ & $(<0,0001)$ & $(<0,0001)$ & $(<0,0001)$ \\
\hline \multirow[t]{2}{*}{ NF2 } & $\overline{0}, 7607$ & 0,2759 & $\overline{0}, 8247$ & $\overline{0,7861}$ & 0,7154 & 1,0000 & $\overline{0}, 7706$ & 0,5569 \\
\hline & $(\leq 0,0001)$ & $(0,0127)$ & $(\leq 0,0001)$ & $(\leq 0,0001)$ & $(<0,0001)$ & $(0,0000)$ & $(<0,0001)$ & $(<0,0001)$ \\
\hline \multirow[t]{2}{*}{ NF3 } & $\overline{0}, 7794$ & 0,2734 & $\overline{0}, 8390$ & 0,9074 & $\overline{0}, 7725$ & 0,7706 & $\overline{1}, 0000$ & $\overline{0}, 6149$ \\
\hline & $(\leq 0,0001)$ & $(0,0135)$ & $(\leq 0,0001)$ & $(\leq 0,0001)$ & $(\leq 0,0001)$ & $(\leq 0,0001)$ & $(0,0000)$ & $(\leq 0,0001)$ \\
\hline \multirow[t]{2}{*}{ NF4 } & $\overline{0}, 6286$ & 0,2206 & $\overline{0,5763}$ & 0,6440 & 0,7755 & $\overline{0,5569}$ & 0,6149 & $\overline{1}, 0000$ \\
\hline & $(\leq 0,0001)$ & $(0,0478)$ & $(\leq 0,0001)$ & $(\leq 0,0001)$ & $(\leq 0,0001)$ & $(\leq 0,0001)$ & $(\leq 0,0001)$ & $(0,0000)$ \\
\hline \multirow{2}{*}{ COMP_NO1 } & 0,5255 & 0,3277 & 0,4578 & 0,5042 & 0,5654 & 0,3651 & 0,4213 & 0,4218 \\
\hline & $(\leq 0,0001)$ & $(0,0028)$ & $(\leq 0,0001)$ & $(\leq 0,0001)$ & $(\leq 0,0001)$ & $(0,0008)$ & $(\leq 0,0001)$ & $(<0,0001)$ \\
\hline \multirow[t]{2}{*}{ COMP_NO2 } & $\overline{0}, 6991$ & 0,3362 & $\overline{0}, 5210$ & 0,6220 & 0,7093 & 0,5078 & $\overline{0}, 5306$ & 0,5183 \\
\hline & $(\leq 0,0001)$ & $(0,0021)$ & $(\leq 0,0001)$ & $(\leq 0,0001)$ & $(\leq 0,0001)$ & $(\leq 0,0001)$ & $(\leq 0,0001)$ & $(<0,0001)$ \\
\hline \multirow[t]{2}{*}{ DC } & $\overline{0}, 7579$ & 0,2302 & $\overline{0}, 6174$ & 0,7150 & 0,7259 & 0,6752 & $\overline{0}, 6182$ & 0,5581 \\
\hline & $(\leq 0,0001)$ & $(0,0387)$ & $(\leq 0,0001)$ & $(\leq 0,0001)$ & $(\leq 0,0001)$ & $(\leq 0,0001)$ & $(\leq 0,0001)$ & $(\leq 0,0001)$ \\
\hline \multirow{2}{*}{ MMSF } & $\overline{0}, 6975$ & 0,2494 & 0,6544 & $\overline{0}, 6792$ & $\overline{0}, 6772$ & 0,6139 & $\overline{0}, 6717$ & 0,5521 \\
\hline & $(\leq 0,0001)$ & $(0,2470)$ & $(\leq 0,0001)$ & $(\leq 0,0001)$ & $(\leq 0,0001)$ & $(\leq 0,0001)$ & $(\leq 0,0001)$ & $(<0,0001)$ \\
\hline \multirow[t]{2}{*}{ MMSC } & 0,7768 & 0,3275 & 0,6055 & 0,6563 & 0,6872 & 0,6495 & 0,6477 & 0,5865 \\
\hline & $(<0,0001)$ & $(0,0028)$ & $(<0,0001)$ & $(\leq 0,0001)$ & $(<0,0001)$ & $(<0,0001)$ & $(<0,0001)$ & $(<0,0001)$ \\
\hline \multirow[t]{2}{*}{ MMSP } & $\overline{0,5728}$ & 0,2359 & $\overline{0,4193}$ & $\overline{0,5049}$ & 0,5527 & 0,4159 & $\overline{0}, 4888$ & $\overline{0}, 3380$ \\
\hline & $(\leq 0,0001)$ & $(0,0340)$ & $(\leq 0,0001)$ & $(\leq 0,0001)$ & $(\leq 0,0001)$ & $(\leq 0,0001)$ & $(\leq 0,0001)$ & $(0,0020)$ \\
\hline \multirow[t]{2}{*}{ MMSE } & $\overline{0}, 7226$ & 0,2558 & 0,6433 & $\overline{0}, 6380$ & $\overline{0}, 6804$ & 0,6309 & $\overline{0,5954}$ & 0,5005 \\
\hline & $(\leq 0,0001)$ & $(0,0211)$ & $(\leq 0,0001)$ & $(\leq 0,0001)$ & $(\leq 0,0001)$ & $(\leq 0,0001)$ & $(\leq 0,0001)$ & $(\leq 0,0001)$ \\
\hline \multirow[t]{2}{*}{ AIE } & 0,8600 & 0,3780 & 0,6490 & 0,7436 & 0,8452 & 0,6889 & 0,6769 & 0,6412 \\
\hline & $(\leq 0,0001)$ & $(0,0005)$ & $(\leq 0,0001)$ & $(\leq 0,0001)$ & $(\leq 0,0001)$ & $(\leq 0,0001)$ & $(\leq 0,0001)$ & $(\leq 0,0001)$ \\
\hline \multirow[t]{2}{*}{$\mathrm{ABP}$} & 0,8301 & 0,3008 & 0,6920 & 0,8115 & 0,8567 & 0,6938 & 0,7581 & 0,6820 \\
\hline & $(\leq 0,0001)$ & $(0,0064)$ & $(\leq 0,0001)$ & $(\leq 0,0001)$ & $(\leq 0,0001)$ & $(\leq 0,0001)$ & $(\leq 0,0001)$ & $(\leq 0,0001)$ \\
\hline \multirow[t]{2}{*}{ PROLIF } & 0,7893 & 0,2271 & 0,5910 & 0,7190 & 0,7504 & 0,6072 & 0,6361 & 0,5177 \\
\hline & $(\leq 0,0001)$ & $(0,0414)$ & $(\leq 0,0001)$ & $(\leq 0,0001)$ & $(\leq 0,0001)$ & $(\leq 0,0001)$ & $(\leq 0,0001)$ & $(\leq 0,0001)$ \\
\hline \multirow[t]{2}{*}{ NFG } & 0,4387 & 0,1086 & 0,1825 & 0,2932 & 0,2853 & 0,1861 & 0,2287 & 0,2404 \\
\hline & $(\leq 0,0001)$ & $(0,3345)$ & $(0,1030)$ & $(0,0079)$ & $(0,0098)$ & $(0,0961)$ & $(0,0400)$ & $(0,0306)$ \\
\hline \multirow[t]{2}{*}{ NGF } & 0,7396 & 0,3344 & 0,6103 & 0,6761 & 0,7228 & 0,6619 & 0,6505 & 0,5705 \\
\hline & $(\leq 0,0001)$ & $(0,0023)$ & $(\leq 0,0001)$ & $(\leq 0,0001)$ & $(\leq 0,0001)$ & $(\leq 0,0001)$ & $(\leq 0,0001)$ & $(\leq 0,0001)$ \\
\hline \multirow[t]{2}{*}{ COMPGRAO } & $\overline{0}, 7099$ & 0,2509 & 0,4833 & 0,5744 & $\overline{0,5776}$ & 0,5395 & 0,5597 & 0,3954 \\
\hline & $(\leq 0,0001)$ & $(0,0238)$ & $(\leq 0,0001)$ & $(\leq 0,0001)$ & $(\leq 0,0001)$ & $(\leq 0,0001)$ & $(\leq 0,0001)$ & $(0,0003)$ \\
\hline COMPESP & 0,9076 & 0,3879 & 0,6571 & 0,7711 & 0,8352 & 0,7394 & 0,7411 & 0,6051 \\
\hline & $(\leq 0,0001)$ & $(0,0003)$ & $(\leq 0,0001)$ & $(\leq 0,0001)$ & $(\leq 0,0001)$ & $(\leq 0,0001)$ & $(\leq 0,0001)$ & $(<0,0001)$ \\
\hline M1000G & $\overline{0,5144}$ & 0,2627 & 0,4137 & $\overline{0}, 3884$ & $\overline{0}, 4358$ & 0,4721 & $\overline{0}, 4177$ & $\overline{0}, 2986$ \\
\hline & $(\leq 0,0001)$ & $(0,0178)$ & $(\leq 0,0001)$ & $(0,0003)$ & $(\leq 0,0001)$ & $(\leq 0,0001)$ & $(\leq 0,0001)$ & $(0,0068)$ \\
\hline
\end{tabular}


Tabela 11. Coeficiente de correlação de Pearson $(n=81)$ entre as variáveis analisadas e nível de significância (entre parêntesis) associado ao teste t

\begin{tabular}{|c|c|c|c|c|c|}
\hline Variável $^{1}$ & $\overline{\mathrm{AIE}}$ & $\overline{\mathrm{ABP}}$ & PROLIF & COMP_NO1 & COMP_NO2 \\
\hline \multirow{2}{*}{ PROD } & 0,8600 & 0,8301 & 0,7893 & 0,5255 & 0,6991 \\
\hline & $(<0,0001)$ & $(\leq 0,0001)$ & $(\leq 0,0001)$ & $(\leq 0,0001)$ & $(\leq 0,0001)$ \\
\hline \multirow[t]{2}{*}{ IAF1 } & 0,3780 & 0,3008 & 0,2271 & 0,3277 & 0,3362 \\
\hline & $(0,0005)$ & $(0,0064)$ & $(0,0414)$ & $(0,0028)$ & $(0,0021)$ \\
\hline \multirow[t]{2}{*}{ IAF2 } & 0,6490 & 0,6920 & 0,5910 & 0,4578 & 0,5210 \\
\hline & $(\leq 0,0001)$ & $(\leq 0,0001)$ & $(\leq 0,0001)$ & $(\leq 0,0001)$ & $(\leq 0,0001)$ \\
\hline \multirow[t]{2}{*}{ IAF3 } & 0,7436 & 0,8115 & 0,7190 & 0,5042 & 0,6220 \\
\hline & $(\leq 0,0001)$ & $(\leq 0,0001)$ & $(\leq 0,0001)$ & $(\leq 0,0001)$ & $(\leq 0,0001)$ \\
\hline \multirow[t]{2}{*}{ IAF4 } & 0,8452 & 0,8567 & 0,7504 & 0,5654 & 0,7093 \\
\hline & $(\leq 0,0001)$ & $(\leq 0,0001)$ & $(\leq 0,0001)$ & $(\leq 0,0001)$ & $(\leq 0,0001)$ \\
\hline \multirow[t]{2}{*}{ NF2 } & 0,6889 & 0,6938 & 0,6072 & 0,3651 & 0,5078 \\
\hline & $(\leq 0,0001)$ & $(\leq 0,0001)$ & $(\leq 0,0001)$ & $(0,0008)$ & $(\leq 0,0001)$ \\
\hline \multirow[t]{2}{*}{ NF3 } & 0,6769 & $\overline{0}, 7581$ & 0,6361 & 0,4213 & 0,5306 \\
\hline & $(<0,0001)$ & $(\leq 0,0001)$ & $(\leq 0,0001)$ & $(<0,0001)$ & $(<0,0001)$ \\
\hline \multirow[t]{2}{*}{ NF4 } & 0,6412 & 0,6820 & 0,5177 & 0,4218 & 0,5183 \\
\hline & $(\leq 0,0001)$ & $(\leq 0,0001)$ & $(\leq 0,0001)$ & $(\leq 0,0001)$ & $(\leq 0,0001)$ \\
\hline \multirow[t]{2}{*}{ COMP_NO1 } & 0,5908 & 0,5634 & 0,4253 & 1,0000 & 0,8333 \\
\hline & $(<0,0001)$ & $(<0,0001)$ & $(\leq 0,0001)$ & $(0,0000)$ & $(\leq 0,0001)$ \\
\hline \multirow[t]{2}{*}{ COMP_NO2 } & 0,7611 & 0,7602 & 0,5800 & 0,8333 & 1,0000 \\
\hline & $(\leq 0,0001)$ & $(\leq 0,0001)$ & $(\leq 0,0001)$ & $(\leq 0,0001)$ & $(0,0000)$ \\
\hline \multirow[t]{2}{*}{$\mathrm{DC}$} & 0,7143 & 0,6892 & 0,5715 & 0,5182 & 0,6641 \\
\hline & $(\leq 0,0001)$ & $(\leq 0,0001)$ & $(\leq 0,0001)$ & $(\leq 0,0001)$ & $(\leq 0,0001)$ \\
\hline \multirow[t]{2}{*}{ MMSF } & 0,6599 & 0,6350 & 0,5720 & 0,5392 & 0,6131 \\
\hline & $(\leq 0,0001)$ & $(\leq 0,0001)$ & $(\leq 0,0001)$ & $(\leq 0,0001)$ & $(\leq 0,0001)$ \\
\hline \multirow[t]{2}{*}{ MMSC } & $\overline{0}, 7419$ & 0,7119 & 0,6508 & 0,5037 & 0,6653 \\
\hline & $(\leq 0,0001)$ & $(\leq 0,0001)$ & $(\leq 0,0001)$ & $(\leq 0,0001)$ & $(\leq 0,0001)$ \\
\hline \multirow[t]{2}{*}{ MMSP } & 0,5675 & 0,5249 & 0,5083 & 0,4174 & 0,5466 \\
\hline & $(\leq 0,0001)$ & $(\leq 0,0001)$ & $(\leq 0,0001)$ & $(\leq 0,0001)$ & $(\leq 0,0001)$ \\
\hline \multirow[t]{2}{*}{ MMSE } & $\overline{0}, 7025$ & $\overline{0}, 6141$ & 0,6833 & 0,4779 & 0,5700 \\
\hline & $(\leq 0,0001)$ & $(\leq 0,0001)$ & $(\leq 0,0001)$ & $(\leq 0,0001)$ & $(\leq 0,0001)$ \\
\hline \multirow[t]{2}{*}{ AIE } & 1,0000 & 0,8994 & 0,7128 & 0,5908 & 0,7611 \\
\hline & $(0,0000)$ & $(\leq 0,0001)$ & $(\leq 0,0001)$ & $(\leq 0,0001)$ & $(\leq 0,0001)$ \\
\hline \multirow[t]{2}{*}{$\mathrm{ABP}$} & 0,8994 & 1,0000 & 0,7090 & 0,5634 & 0,7602 \\
\hline & $(\leq 0,0001)$ & $(0,0000)$ & $(\leq 0,0001)$ & $(\leq 0,0001)$ & $(\leq 0,0001)$ \\
\hline \multirow[t]{2}{*}{ PROLIF } & 0,7128 & 0,7090 & 1,0000 & 0,4253 & 0,5800 \\
\hline & $(\leq 0,0001)$ & $(\leq 0,0001)$ & $(0,0000)$ & $(\leq 0,0001)$ & $(\leq 0,0001)$ \\
\hline \multirow[t]{2}{*}{ NFG } & 0,3177 & 0,3178 & 0,4081 & 0,1392 & 0,2595 \\
\hline & $(0,0038)$ & $(0,0038)$ & $(0,0002)$ & $(0,2151)$ & $(0,0193)$ \\
\hline \multirow[t]{2}{*}{ NGF } & 0,7116 & 0,7699 & 0,6981 & 0,4319 & 0,6154 \\
\hline & $(\leq 0,0001)$ & $(\leq 0,0001)$ & $(\leq 0,0001)$ & $(\leq 0,0001)$ & $(\leq 0,0001)$ \\
\hline \multirow[t]{2}{*}{ COMPGRAO } & 0,6266 & 0,6147 & 0,5178 & 0,3781 & 0,4723 \\
\hline & $(\leq 0,0001)$ & $(\leq 0,0001)$ & $(\leq 0,0001)$ & $(0,0005)$ & $(\leq 0,0001)$ \\
\hline \multirow[t]{2}{*}{ COMPESP } & 0,8408 & 0,8429 & 0,7731 & 0,5080 & 0,7117 \\
\hline & $(\leq 0,0001)$ & $(\leq 0,0001)$ & $(\leq 0,0001)$ & $(\leq 0,0001)$ & $(\leq 0,0001)$ \\
\hline \multirow[t]{2}{*}{ M1000G } & 0,4966 & 0,4042 & 0,1689 & 0,3205 & 0,3063 \\
\hline & $(\leq 0,0001)$ & $(0,0002)$ & $(0,1317)$ & $(0,0035)$ & $(0,0054)$ \\
\hline
\end{tabular}


Tabela 12. Coeficiente de correlação de Pearson $(n=81)$ entre as variáveis analisadas e nível de significância (entre parêntesis) associado ao teste $\mathrm{t}$

\begin{tabular}{|c|c|c|c|c|c|}
\hline Variável $^{1}$ & $\overline{\mathrm{DC}}$ & MMSF & MMSC & MMSP & MMSE \\
\hline \multirow[t]{2}{*}{ PROD } & 0,7579 & 0,6975 & 0,7768 & 0,5728 & 0,7226 \\
\hline & $(\leq 0,0001)$ & $(\leq 0,0001)$ & $(\leq 0,0001)$ & $(\leq 0,0001)$ & $(\leq 0,0001)$ \\
\hline \multirow[t]{2}{*}{ IAF1 } & 0,2302 & 0,2494 & 0,3275 & 0,2359 & 0,2558 \\
\hline & $(0,0387)$ & $(0,0247)$ & $(0,0028)$ & $(0,0340)$ & $(0,0211)$ \\
\hline \multirow[t]{2}{*}{ IAF2 } & 0,6174 & 0,6544 & 0,6055 & 0,4193 & 0,6433 \\
\hline & $(\leq 0,0001)$ & $(\leq 0,0001)$ & $(\leq 0,0001)$ & $(\leq 0,0001)$ & $(\leq 0,0001)$ \\
\hline \multirow[t]{2}{*}{ IAF3 } & 0,7150 & 0,6792 & 0,6563 & 0,5049 & 0,6380 \\
\hline & $(\leq 0,0001)$ & $(\leq 0,0001)$ & $(\leq 0,0001)$ & $(\leq 0,0001)$ & $(\leq 0,0001)$ \\
\hline \multirow[t]{2}{*}{ IAF4 } & 0,7259 & 0,6772 & 0,6872 & 0,5527 & 0,6804 \\
\hline & $(\leq 0,0001)$ & $(\leq 0,0001)$ & $(\leq 0,0001)$ & $(\leq 0,0001)$ & $(\leq 0,0001)$ \\
\hline \multirow[t]{2}{*}{ NF2 } & 0,6752 & 0,6139 & 0,6495 & 0,5159 & 0,6309 \\
\hline & $(\leq 0,0001)$ & $(\leq 0,0001)$ & $(\leq 0,0001)$ & $(\leq 0,0001)$ & $(\leq 0,0001)$ \\
\hline \multirow[t]{2}{*}{ NF3 } & 0,6182 & 0,6717 & 0,6477 & 0,4888 & 0,5954 \\
\hline & $(<0,0001)$ & $(<0,0001)$ & $(<0,0001)$ & $(<0,0001)$ & $(<0,0001)$ \\
\hline \multirow[t]{2}{*}{ NF4 } & 0,5581 & 0,5521 & 0,5865 & 0,3380 & 0,5005 \\
\hline & $(\leq 0,0001)$ & $(\leq 0,0001)$ & $(\leq 0,0001)$ & $(0,0020)$ & $(\leq 0,0001)$ \\
\hline \multirow{2}{*}{ COMP_NO1 } & 0,5182 & 0,5392 & 0,5037 & 0,4174 & 0,4779 \\
\hline & $(\leq 0,0001)$ & $(\leq 0,0001)$ & $(\leq 0,0001)$ & $(\leq 0,0001)$ & $(\leq 0,0001)$ \\
\hline \multirow[t]{2}{*}{ COMP_NO2 } & 0,6641 & 0,6131 & 0,6653 & 0,5466 & 0,5700 \\
\hline & $(\leq 0,0001)$ & $(\leq 0,0001)$ & $(\leq 0,0001)$ & $(\leq 0,0001)$ & $(\leq 0,0001)$ \\
\hline \multirow[t]{2}{*}{ DC } & 1,0000 & $\overline{0}, 6562$ & $\overline{0}, 6911$ & 0,5216 & 0,5729 \\
\hline & $(0,0000)$ & $(\leq 0,0001)$ & $(\leq 0,0001)$ & $(\leq 0,0001)$ & $(\leq 0,0001)$ \\
\hline \multirow[t]{2}{*}{ MMSF } & 0,6562 & 1,0000 & 0,8118 & 0,6002 & 0,7483 \\
\hline & $(\leq 0,0001)$ & $(0,0000)$ & $(\leq 0,0001)$ & $(\leq 0,0001)$ & $(\leq 0,0001)$ \\
\hline \multirow[t]{2}{*}{ MMSC } & 0,6911 & 0,8118 & 1,0000 & $\overline{0}, 6613$ & 0,7292 \\
\hline & $(\leq 0,0001)$ & $(\leq 0,0001)$ & $(0,0000)$ & $(\leq 0,0001)$ & $(\leq 0,0001)$ \\
\hline \multirow[t]{2}{*}{ MMSP } & 0,5216 & 0,6002 & 0,6613 & 1,0000 & 0,5825 \\
\hline & $(\leq 0,0001)$ & $(\leq 0,0001)$ & $(\leq 0,0001)$ & $(0,0000)$ & $(\leq 0,0001)$ \\
\hline \multirow[t]{2}{*}{ MMSE } & 0,5729 & $\overline{0}, 7483$ & $\overline{0}, 7292$ & 0,5825 & 1,0000 \\
\hline & $(\leq 0,0001)$ & $(\leq 0,0001)$ & $(\leq 0,0001)$ & $(\leq 0,0001)$ & $(0,0000)$ \\
\hline \multirow[t]{2}{*}{ AIE } & $\overline{0,7143}$ & 0,6599 & 0,7419 & 0,5675 & 0,7025 \\
\hline & $(\leq 0,0001)$ & $(\leq 0,0001)$ & $(\leq 0,0001)$ & $(\leq 0,0001)$ & $(\leq 0,0001)$ \\
\hline \multirow[t]{2}{*}{$\mathrm{ABP}$} & 0,6892 & 0,6350 & 0,7119 & 0,5249 & 0,6141 \\
\hline & $(\leq 0,0001)$ & $(\leq 0,0001)$ & $(\leq 0,0001)$ & $(\leq 0,0001)$ & $(\leq 0,0001)$ \\
\hline \multirow[t]{2}{*}{ PROLIF } & 0,5715 & 0,5720 & 0,6508 & 0,5083 & 0,6833 \\
\hline & $(\leq 0,0001)$ & $(\leq 0,0001)$ & $(\leq 0,0001)$ & $(\leq 0,0001)$ & $(\leq 0,0001)$ \\
\hline \multirow[t]{2}{*}{ NFG } & 0,2834 & 0,2933 & 0,3938 & 0,2041 & 0,3203 \\
\hline & $(0,0103)$ & $(0,0079)$ & $(0,0003)$ & $(0,0676)$ & $(0,0035)$ \\
\hline \multirow[t]{2}{*}{ NGF } & 0,6382 & 0,6435 & 0,6707 & 0,4730 & 0,5738 \\
\hline & $(\leq 0,0001)$ & $(\leq 0,0001)$ & $(\leq 0,0001)$ & $(\leq 0,0001)$ & $(\leq 0,0001)$ \\
\hline \multirow[t]{2}{*}{ COMPGRAO } & 0,4402 & 0,5628 & 0,6053 & 0,4373 & 0,4719 \\
\hline & $(\leq 0,0001)$ & $(\leq 0,0001)$ & $(\leq 0,0001)$ & $(\leq 0,0001)$ & $(\leq 0,0001)$ \\
\hline \multirow[t]{2}{*}{ COMPESP } & 0,6865 & 0,7245 & 0,7551 & 0,5904 & 0,7246 \\
\hline & $(\leq 0,0001)$ & $(\leq 0,0001)$ & $(\leq 0,0001)$ & $(\leq 0,0001)$ & $(\leq 0,0001)$ \\
\hline \multirow[t]{2}{*}{ M1000G } & 0,3512 & 0,3972 & 0,3676 & 0,3045 & 0,4009 \\
\hline & $(0,0013)$ & $(0,0002)$ & $(0,0007)$ & $(0,0057)$ & $(0,0002)$ \\
\hline
\end{tabular}


Tabela 13. Coeficiente de correlação de Pearson $(n=81)$ entre as variáveis analisadas e nível de significância (entre parêntesis) associado ao teste t

\begin{tabular}{|c|c|c|c|c|c|}
\hline Variável $^{1}$ & NFG & NGF & COMPGRAO & COMPESP & M1000G \\
\hline \multirow[t]{2}{*}{ PROD } & 0,4387 & 0,7396 & 0,7099 & 0,9076 & 0,5144 \\
\hline & $(\leq 0,0001)$ & $(\leq 0,0001)$ & $(\leq 0,0001)$ & $(\leq 0,0001)$ & $(\leq 0,0001)$ \\
\hline \multirow{2}{*}{ IAF1 } & 0,1086 & 0,3344 & 0,2509 & 0,3879 & 0,2627 \\
\hline & $(0,3345)$ & $(0,0023)$ & $(0,0238)$ & $(0,0003)$ & $(0,0178)$ \\
\hline \multirow[t]{2}{*}{ IAF2 } & 0,1825 & 0,6103 & 0,4833 & 0,6571 & 0,4137 \\
\hline & $(0,1030)$ & $(\leq 0,0001)$ & $(\leq 0,0001)$ & $(\leq 0,0001)$ & $(\leq 0,0001)$ \\
\hline \multirow[t]{2}{*}{ IAF3 } & 0,2932 & 0,6761 & 0,5744 & 0,7711 & 0,3884 \\
\hline & $(0,0079)$ & $(\leq 0,0001)$ & $(\leq 0,0001)$ & $(\leq 0,0001)$ & $(0,0003)$ \\
\hline \multirow[t]{2}{*}{ IAF4 } & 0,2853 & 0,7228 & 0,5776 & 0,8352 & 0,4358 \\
\hline & $(0,0098)$ & $(\leq 0,0001)$ & $(\leq 0,0001)$ & $(\leq 0,0001)$ & $(\leq 0,0001)$ \\
\hline \multirow[t]{2}{*}{ NF2 } & 0,1861 & 0,6619 & 0,5395 & 0,7394 & 0,4721 \\
\hline & $(0,0961)$ & $(\leq 0,0001)$ & $(\leq 0,0001)$ & $(\leq 0,0001)$ & $(<0,0001)$ \\
\hline \multirow[t]{2}{*}{ NF3 } & 0,2287 & 0,6505 & 0,5597 & 0,7411 & 0,4177 \\
\hline & $(0,0400)$ & $(\leq 0,0001)$ & $(\leq 0,0001)$ & $(\leq 0,0001)$ & $(<0,0001)$ \\
\hline \multirow[t]{2}{*}{ NF4 } & 0,2404 & 0,5705 & 0,3954 & 0,6051 & 0,2986 \\
\hline & $(0,0306)$ & $(<0,0001)$ & $(0,0003)$ & $(<0,0001)$ & $(0,0068)$ \\
\hline \multirow[t]{2}{*}{ COMP_NO1 } & 0,1392 & 0,4319 & 0,3781 & 0,5080 & 0,3205 \\
\hline & $(0,2151)$ & $(\leq 0,0001)$ & $(0,0005)$ & $(\leq 0,0001)$ & $(0,0035)$ \\
\hline \multirow[t]{2}{*}{ COMP_NO2 } & 0,2595 & 0,6154 & 0,4723 & 0,7117 & 0,3063 \\
\hline & $(0,0193)$ & $(\leq 0,0001)$ & $(\leq 0,0001)$ & $(\leq 0,0001)$ & $(0,0054)$ \\
\hline \multirow[t]{2}{*}{ DC } & 0,2834 & 0,6382 & 0,4402 & 0,6865 & 0,3512 \\
\hline & $(0,0103)$ & $(\leq 0,0001)$ & $(\leq 0,0001)$ & $(\leq 0,0001)$ & $(0,0013)$ \\
\hline \multirow[t]{2}{*}{ MMSF } & 0,2933 & 0,6435 & 0,5628 & 0,7245 & 0,3972 \\
\hline & $(0,0079)$ & $(\measuredangle 0,0001)$ & $(\leq 0,0001)$ & $(\leq 0,0001)$ & $(0,0002)$ \\
\hline \multirow[t]{2}{*}{ MMSC } & 0,3938 & 0,6707 & 0,6053 & 0,7551 & 0,3676 \\
\hline & $(0,0003)$ & $(\leq 0,0001)$ & $(\leq 0,0001)$ & $(\leq 0,0001)$ & $(0,0007)$ \\
\hline \multirow[t]{2}{*}{ MMSP } & 0,2041 & 0,4730 & 0,4373 & 0,5904 & 0,3045 \\
\hline & $(0,0676)$ & $(\measuredangle 0,0001)$ & $(\leq 0,0001)$ & $(\leq 0,0001)$ & $(0,0057)$ \\
\hline \multirow[t]{2}{*}{ MMSE } & 0,3203 & 0,5738 & 0,4719 & 0,7246 & 0,4009 \\
\hline & $(0,0035)$ & $(\measuredangle 0,0001)$ & $(\leq 0,0001)$ & $(\leq 0,0001)$ & $(0,0002)$ \\
\hline \multirow{2}{*}{ AIE } & 0,3177 & 0,7116 & $\overline{0}, 6266$ & $\overline{0}, 8408$ & 0,4966 \\
\hline & $(0,0038)$ & $(\leq 0,0001)$ & $(\leq 0,0001)$ & $(\leq 0,0001)$ & $(\leq 0,0001)$ \\
\hline \multirow[t]{2}{*}{$\mathrm{ABP}$} & 0,3178 & 0,7699 & 0,6147 & 0,8429 & 0,4042 \\
\hline & $(0,0038)$ & $(\measuredangle 0,0001)$ & $(\leq 0,0001)$ & $(\leq 0,0001)$ & $(0,0002)$ \\
\hline \multirow[t]{2}{*}{ PROLIF } & 0,4081 & 0,6981 & 0,5178 & 0,7731 & 0,1689 \\
\hline & $(0,0002)$ & $(<0,0001)$ & $(<0,0001)$ & $(<0,0001)$ & $(0,1317)$ \\
\hline \multirow[t]{2}{*}{ NFG } & 1,0000 & 0,2697 & 0,4405 & 0,3721 & $-0,0284$ \\
\hline & $(0,0000)$ & $(0,0149)$ & $(\leq 0,0001)$ & $(0,0006)$ & $(0,8007)$ \\
\hline \multirow[t]{2}{*}{ NGF } & 0,2697 & 1,0000 & 0,5330 & 0,7999 & 0,3464 \\
\hline & $(0,0149)$ & $(0,0000)$ & $(\leq 0,0001)$ & $(\leq 0,0001)$ & $(0,0015)$ \\
\hline \multirow[t]{2}{*}{ COMPGRAO } & 0,4405 & 0,5330 & 1,0000 & 0,7443 & 0,6044 \\
\hline & $(\leq 0,0001)$ & $(\leq 0,0001)$ & $(0,0000)$ & $(\leq 0,0001)$ & $(\leq 0,0001)$ \\
\hline \multirow[t]{2}{*}{ COMPESP } & 0,3721 & 0,7999 & 0,7443 & 1,0000 & 0,4813 \\
\hline & $(0,0006)$ & $(\leq 0,0001)$ & $(\leq 0,0001)$ & $(0,0000)$ & $(\leq 0,0001)$ \\
\hline \multirow[t]{2}{*}{ M1000G } & $-0,0284$ & 0,3464 & 0,6044 & 0,4813 & 1,0000 \\
\hline & $(0,8007)$ & $(0,0015)$ & $(\leq 0,0001)$ & $(\leq 0,0001)$ & $(0,0000)$ \\
\hline
\end{tabular}




\subsubsection{Relação entre as variáveis estudadas}

Tabela 14. Estimativas dos parâmetros do modelo de regressão polinomial quadrático, com os respectivos valores de erro padrão, que descrevem a relação entre as variáveis estudadas e as doses de $\mathrm{N}$ aplicadas

\begin{tabular}{|c|c|c|c|c|c|}
\hline Variável & Parâmetro & Estimativa & Erro padrão & $\mathrm{GL}^{2}$ & $\mathrm{PROB}^{3}$ \\
\hline $\mathrm{ABP}$ & Intercepto & 1,8678000 & 0,0204100 & 72 & $<0,0001$ \\
\hline $\mathrm{ABP}$ & Linear & 0,0035660 & 0,0004340 & 72 & $<0,0001$ \\
\hline $\mathrm{ABP}$ & Quadrático & $-8,19.10^{-6}$ & $1,736.10^{-6}$ & 72 & $<0,0001$ \\
\hline AIE & Intercepto & 0,8778000 & 0,0154300 & 72 & $<0,0001$ \\
\hline AIE & Linear & 0,0032130 & 0,0003280 & 72 & $<0,0001$ \\
\hline AIE & Quadrático & $-8,18 \cdot 10^{-6}$ & $1,312.10^{-6}$ & 72 & $<0,0001$ \\
\hline ALT_NO2 & Intercepto & 7,0037000 & 0,1889000 & 72 & $<0,0001$ \\
\hline ALT_NO2 & Linear & 0,0205900 & 0,0040130 & 72 & $<0,0001$ \\
\hline ALT_NO2 & Quadrático & $-0,0000400$ & 0,0000160 & 72 & $\overline{0}, 0088$ \\
\hline COMPESP & Intercepto & 14,6648148 & 0,1395515 & 72 & $<0,0001$ \\
\hline COMPESP & Linear & 0,0383302 & 0,0029649 & 72 & $<0,0001$ \\
\hline COMPESP & Quadrático & $-0,0000938$ & 0,0000118 & 72 & $<0,0001$ \\
\hline DC & Intercepto & 1,8967000 & 0,0271500 & 72 & $<0,0001$ \\
\hline DC & Linear & 0,0043550 & 0,0005770 & 72 & $<0,0001$ \\
\hline DC & Quadrático & $-0,0000100$ & $2,309 \cdot 10^{-6}$ & 72 & $<0,0001$ \\
\hline IAF3 & Intercepto & 2,2062963 & 0,0789094 & 72 & $\leq 0,0001$ \\
\hline IAF3 & Linear & 0,0125354 & 0,0016765 & 72 & $<0,0001$ \\
\hline IAF3 & Quadrático & $-0,0000321$ & 0,0000067 & 72 & $\overline{<} 0,0001$ \\
\hline IAF4 & Intercepto & 2,6337037 & 0,0755111 & 72 & $\leq 0,0001$ \\
\hline IAF4 & Linear & 0,0153564 & 0,0016043 & 72 & $<0,0001$ \\
\hline IAF4 & Quadrático & $-0,0000343$ & 0,0000064 & 72 & $\leq 0,0001$ \\
\hline $\mathrm{NF} 2$ & Intercepto & 6,4444444 & 0,1196560 & 72 & $<0,0001$ \\
\hline $\mathrm{NF} 2$ & Linear & 0,0189814 & 0,0025422 & 72 & $<0,0001$ \\
\hline $\mathrm{NF} 2$ & Quadrático & $-0,0000527$ & 0,0000101 & 72 & $<0,0001$ \\
\hline NF3 & Intercepto & 12,0555555 & 0,1420423 & 72 & $\leq 0,0001$ \\
\hline NF3 & Linear & 0,0247685 & 0,0030178 & 72 & $<0,0001$ \\
\hline NF3 & Quadrático & $-0,0000688$ & 0,0000120 & 72 & $<0,0001$ \\
\hline MMSE & Intercepto & 169,5700000 & 10,1860000 & 72 & $<0,0001$ \\
\hline MMSE & Linear & 1,0228000 & 0,2164000 & 72 & $<0,0001$ \\
\hline MMSE & Quadrático & $-0,0022400$ & 0,0008660 & 72 & $\overline{0}, 0119$ \\
\hline PROD & Intercepto & 4354,7318519 & 227,8230297 & 78 & $\leq 0,0001$ \\
\hline PROD & Linear & 47,6552314 & 4,8403086 & 78 & $<0,0001$ \\
\hline PROD & Quadrático & $-0,1176081$ & 0,0193767 & 78 & $<0,0001$ \\
\hline PROLIF & Intercepto & 1,0748148 & 0,0191126 & 72 & $<0,0001$ \\
\hline PROLIF & Linear & 0,0027592 & 0,0004060 & 72 & $\leq 0,0001$ \\
\hline PROLIF & Quadrático & $-0,0000076$ & 0,0001625 & 72 & $<0,0001$ \\
\hline
\end{tabular}


Tabela 15. Estimativas dos parâmetros do modelo de regressão polinomial quadrático, com os respectivos valores de erro padrão, que descrevem a relação entre as variáveis NGF e IAF2 e as doses de boro em cada dose de nitrogênio (DN, $\mathrm{kg} \cdot \mathrm{ha}^{-1}$ )

\begin{tabular}{ccccccc}
\hline Variável $^{1}$ & Parâmetro & DN & Estimativa & Erro padrão & GL $^{2}$ & PROB $^{3}$ \\
\hline NGF & Intercepto & 0 & 29,0586956 & 0,4407994 & 54 & $\leq 0,0001$ \\
NGF & Intercepto & 120 & 37,3830830 & 0,4407994 & 54 & $\leq 0,0001$ \\
NGF & Intercepto & 240 & 38,1283399 & 0,4407994 & 54 & $\leq 0,0001$ \\
NGF & Linear & 0 & $-1,0876853$ & 0,4626170 & 54 & 0,0224 \\
NGF & Linear & 120 & $-0,8613233$ & 0,4626170 & 54 & 0,0681 \\
NGF & Linear & 240 & 0,9158862 & 0,4626170 & 54 & 0,0528 \\
NGF & Quadrático & 0 & 0,2732982 & 0,0600057 & 54 & $\leq 0,0001$ \\
NGF & Quadrático & 120 & 0,1381816 & 0,0600057 & 54 & 0,0252 \\
NGF & Quadrático & 240 & $-0,2284708$ & 0,0600057 & 54 & 0,0004 \\
IAF2 & Intercepto & 0 & 1,0723188 & 0,0618757 & 54 & $\leq 0,0001$ \\
IAF2 & Intercepto & 120 & 1,6224769 & 0,0618757 & 54 & $\leq 0,0001$ \\
IAF2 & Intercepto & 240 & 1,7658629 & 0,0618757 & 54 & $\leq 0,0001$ \\
IAF2 & Linear & 0 & $-0,0041089$ & 0,0649383 & 54 & 0,9498 \\
IAF2 & Linear & 120 & $-0,0586234$ & 0,0649383 & 54 & 0,3707 \\
IAF2 & Linear & 240 & $-0,1749634$ & 0,0649383 & 54 & 0,0094 \\
IAF2 & Quadrático & 0 & 0,0020874 & 0,0084231 & 54 & 0,8052 \\
IAF2 & Quadrático & 120 & 0,0083575 & 0,0084231 & 54 & 0,3255 \\
IAF2 & Quadrático & 240 & 0,0164511 & 0,0084231 & 54 & 0,0560 \\
\hline Iista de símbolos & & & & & \\
2 Graus de liberdade & & & & &
\end{tabular}


Tabela 16. Estimativas dos parâmetros do modelo de regressão polinomial quadrático, com os respectivos valores de erro padrão, que descrevem a relação entre as variáveis número de folhas fotossinteticamente ativas aos 65 dias após a emergência (NF4) e massa de mil grãos (M1000G) e as doses de zinco em cada dose de nitrogênio (DN, kg.ha ${ }^{-1}$ )

\begin{tabular}{ccccccc}
\hline Variável $^{\text {1 }}$ & Parâmetro & DN & Estimativa & Erro padrão & GL $^{2}$ & PROB $^{3}$ \\
\hline NF4 & Intercepto & 0 & 17,9881000 & 0,1269000 & 54 & $\leq 0,0001$ \\
NF4 & Intercepto & 120 & 18,8235000 & 0,1269000 & 54 & $\leq 0,0001$ \\
NF4 & Intercepto & 240 & 19,2905000 & 0,1269000 & 54 & $\leq 0,0001$ \\
NF4 & Linear & 0 & 0,0335400 & 0,0665900 & 54 & 0,6165 \\
NF4 & Linear & 120 & 0,0258900 & 0,0665900 & 54 & 0,6989 \\
NF4 & Linear & 240 & $-0,0169300$ & 0,0665900 & 54 & 0,8003 \\
NF4 & Quadrático & 0 & $-0,0026500$ & 0,0041800 & 54 & 0,5427 \\
NF4 & Quadrático & 120 & $-0,0015300$ & 0,0041800 & 54 & 0,7240 \\
NF4 & Quadrático & 240 & 0,0016500 & 0,0041800 & 54 & 0,7044 \\
M1000G & Intercepto & 0 & 217,7524900 & 3,9937700 & 54 & $\leq 0,0001$ \\
M1000G & Intercepto & 120 & 239,4208000 & 3,9937700 & 54 & $\leq 0,0001$ \\
M1000G & Intercepto & 240 & 246,4448700 & 3,9937700 & 54 & $\leq 0,0001$ \\
M1000G & Linear & 0 & 3,3420200 & 2,0957200 & 54 & 0,1166 \\
M1000G & Linear & 120 & 0,5422800 & 2,0957200 & 54 & 0,7968 \\
M1000G & Linear & 240 & $-2,3982100$ & 2,0957200 & 54 & 0,2575 \\
M1000G & Quadrático & 0 & $-0,1275100$ & 0,1359100 & 54 & 0,3524 \\
M1000G & Quadrático & 120 & $-0,1088300$ & 0,1359100 & 54 & 0,4268 \\
M1000G & Quadrático & 240 & 0,1673600 & 0,1359100 & 54 & 0,2235 \\
\hline 1 Lista de símbolos & & & & & \\
2 Graus de liberdade & & & & &
\end{tabular}


Tabela 21. Modelo referente à massa de matéria seca de colmo (MMSC, d.planta ${ }^{-1}$ ) em função da aplicação de doses de nitrogênio $\left(\mathrm{DN}, \mathrm{kg}_{\mathrm{n}} \mathrm{ha}^{-1}\right)$ e de zinco (DZn, kg.ha-1)

\begin{tabular}{cccccc}
\hline \multicolumn{2}{c}{$M M S C=a+b \cdot D N+c \cdot D N^{2}+d \cdot D Z n+e . D Z n^{2}+f \cdot D Z n^{3}$} & \multicolumn{2}{c}{$r^{2}=0,622$} \\
Parâmetro & Valor & Erro padrão & Valor t & Intervalo de confianca (90\%) \\
\hline a & 80,30447857 & 3,564090403 & 22,53154929 & 74,38688448 & 86,22207267 \\
b & 0,590969907 & 0,067468833 & 8,759154188 & 0,478948853 & 0,702990962 \\
c & $-0,00158391$ & 0,000270091 & $-5,86435373$ & $-0,00203236$ & $-0,00113547$ \\
d & 4,258297649 & 3,222039654 & 1,321615531 & $-1,09137665$ & 9,607971951 \\
e & $-0,43412006$ & 0,654155242 & $-0,66363461$ & $-1,52023875$ & 0,651998631 \\
f & 0,010875338 & 0,029261745 & 0,37165721 & $-0,03770904$ & 0,05945972 \\
\hline
\end{tabular}

Tabela 22. Análise de variância referente ao modelo de estimativa da massa de matéria seca de colmo (MMSC, g.planta ${ }^{-1}$ ), em função da aplicação de doses de nitrogênio (DN, kg. ha $\left.{ }^{-1}\right)$ e de zinco (DZn, kg.ha $\left.{ }^{-1}\right)$

\begin{tabular}{ccccc}
\hline $\begin{array}{c}\text { Causa de } \\
\text { varia,cão }\end{array}$ & $\begin{array}{c}\text { Soma de } \\
\text { quadrados }\end{array}$ & $\begin{array}{c}\text { Graus de } \\
\text { liberdade }\end{array}$ & $\begin{array}{c}\text { Quadrado } \\
\text { médio }\end{array}$ & Valor F \\
\hline Regressão & 60960,862 & 5 & 12192,172 & 33,5833 \\
Erro & 37030,383 & 102 & 363,04297 & \\
Total & 97991,245 & 107 & & \\
\hline
\end{tabular}


Tabela 23. Modelo referente à massa de matéria seca de folhas (MMSF, g.planta ${ }^{-1}$ ), em função da aplicação de doses de nitrogênio (DN, kg.ha $\left.{ }^{-1}\right)$ e de zinco (DZn, $\mathrm{kg} . \mathrm{ha}^{-1}$ )

\begin{tabular}{cccccc}
\hline \multicolumn{2}{c}{ MMSF $=\mathrm{a}+\mathrm{b} \cdot \mathrm{DN}+\mathrm{c} \cdot \mathrm{DN}^{2}+\mathrm{d} \cdot \operatorname{Ln}(\mathrm{DZn})+\mathrm{e} \cdot[\mathrm{Ln}(\mathrm{DZn})]^{2}$} & \multicolumn{2}{c}{$\mathrm{r}^{2}=0,538$} \\
\multirow{2}{*}{ Parâmetro } & Valor & Erro padrão & Valor t & \multicolumn{2}{c}{ Intervalo de confiança (90\%) } \\
\cline { 2 - 7 } a & 67,26363623 & 5,326238501 & 12,62873155 & 58,42108126 & 76,1061912 \\
b & 0,273978009 & 0,049856589 & 5,495322031 & 0,191206721 & 0,356749298 \\
c & $-0,00056525$ & 0,000199586 & $-2,83210544$ & $-0,0008966$ & $-0,0002339$ \\
d & 8,235420974 & 2,609264953 & 3,156222585 & 3,903551725 & 12,56729022 \\
e & 0,011943802 & 0,003786806 & 3,154056737 & 0,005656993 & 0,018230611
\end{tabular}

Tabela 24. Análise de variância referente ao modelo de estimativa da massa de matéria seca de folhas (MMSF, g.planta ${ }^{-1}$ ), em função da aplicação de doses de nitrogênio (DN, kg.ha $\left.{ }^{-1}\right)$ e de zinco (DZn, kg.ha $\left.{ }^{-1}\right)$

\begin{tabular}{ccccc}
\hline $\begin{array}{c}\text { Causa de } \\
\text { varia,cão }\end{array}$ & $\begin{array}{c}\text { Soma de } \\
\text { quadrados }\end{array}$ & $\begin{array}{c}\text { Graus de } \\
\text { liberdade }\end{array}$ & $\begin{array}{c}\text { Quadrado } \\
\text { médio }\end{array}$ & Valor F \\
\hline Regressão & 23807,983 & 4 & 5951,9957 & 30,0238 \\
Erro & 20418,977 & 103 & 198,24249 & \\
Total & 44226,96 & 107 & & \\
\hline
\end{tabular}

\subsection{Avaliações fitotécnicas}

\subsubsection{Número de folhas fotossinteticamente ativas por planta e índice de área foliar}

Segundo Fancelli \& Dourado Neto (2000), a produtividade de grãos da cultura de milho é diretamente dependente da atividade fotossintética da [planta, sendo que a fotossíntese, por sua vez, depende da extensão da área foliar e do tempo permanência das folhas em plena atividade na planta. Fanelli (1986) cita que a redução do índice de área foliar (IAF), o qual expressa a relação entre a área foliar total da planta e a área de 
solo ocupado pela mesma, pode resultar na diminuição da taxa de interceptação de radiação solar com conseqüente redução de produção de carboidratos e de produtividade.

Dessa maneira, julgourse importante determinar o índice de área foliar (IAF) das plantas estudadas, o qual depende diretamente da população, do estado fitossanitário das plantas, do número de folhas fotossinteticamente ativas (NF), do tamanho das folhas e do estado nutricional das plantas.

Ao observar os valores de NF (Tabela 1) e IAF (Tabela 2), verificourse que até 20 dias após a emergência (DAE), não houve diferença significativa entre o número de folhas fotossinteticamente ativas por planta (NF1) e entre o índice de área foliar (IAF1), uma vez que em todos os tratamentos as plantas apresentavam 4 folhas plenamente expandidas.

Somente nas avaliações efetuadas aos 41, 49 e 65 (florescimento) dias após a emergência das plantas, verificourse que a adição de nitrogênio em doses crescentes proporcionou aumento do NF e do IAF, o que certamente contribuiu para o suprimento de fotoassimilados e, conseqüentemente, para o incremento na produtividade. Esse resultado confirma o exposto por diversos autores que afirmam que até a emissão da quarta folha a absorção e a demanda de nutrientes (inclusive de nitrogênio) pelas plantas de milho é pequena, havendo grande aumento na absorção e na necessidade dos mesmos a partir da emissão da quinta folha (fase a partir da qual os nutrientes devem estar prontamente disponíveis para as plantas para que a produtividade não seja afetada). Os resultados também estão de acordo com Fancelli \& Dourado Neto (2000), os quais sugerem que o ideal é que a aplicação de nitrogênio em cobertura na cultura de milho seja efetuada quando as plantas apresentarem 4 folhas plenamente desdobradas, para que o mesmo esteja plenamente disponível para a planta a partir da emissão da quinta folha.

Assim, na avaliação efetuada aos 41 dias após a emergência, ao observar o resultado do teste $\mathrm{F}$ (Tabela 7), para a variável índice de área foliar (IAF2), foi possível verificar nível significância de 4,0\% para a fonte de variação dose de nitrogênio (DN) o que indica ter havido influência significativa das mesmas para a variável em questão. Observoutse que o aumento das doses de nitrogênio (DN) proporcionou um acréscimo 
significativo no número de folhas fotossinteticamente ativas por planta (NF2) e no índice de área foliar (IAF2), sendo que a aplicação de $120 \mathrm{~kg} \cdot \mathrm{ha}^{-1}$ de $\mathrm{N}$ propiciou aumento de aproximadamente $23 \%$ no NF2 (Figura 1) e de aproximadamente 50\% no IAF2, em relação aos tratamentos em que a aplicação de nitrogênio não foi efetuada (0 kg.há ${ }^{-1}$ de N). No entanto, ao elevar a dose de 120 para $240 \mathrm{~kg} \mathrm{ha}^{-1}$ de $\mathrm{No}$ aumento no IAF2 foi menos expressivo (8\%), o que leva a concluir que o acréscimo de IAF2 foi devido ao aumento no tamanho das folhas e não ao número de folhas por planta (NF2). Tal afirmação pode ser confirmada ao analisar a Tabela 14, na qual observa-se que o coeficiente de correlação de Pearson entre as IAF2 e NF2 não é muito alto $(0,62)$.

Quanto aos micronutrientes estudados, observou-se que as doses crescentes de zinco não influenciaram significativamente o NF2 e o IAF2. Porém o uso de boro em doses crescentes exerceu influência sobre o índice de área foliar determinado aos 41 dias após a emergência (IAF2). Na Tabela 19 pode ser observado que houve resposta quadrática da variância IAF2 (nível de significância de 5,6\%) à aplicação de boro apenas quando foi aplicado nitrogênio na dose de $240 \mathrm{~kg} \cdot \mathrm{ha}^{-1}$, sendo que, conforme análise de regressão dos resultados apresentados na Figura 2, nos tratamentos com $240 \mathrm{~kg} \cdot \mathrm{ha}^{-1} \mathrm{de}$ $\mathrm{N}$, a elevação nas doses de boro (DB) provocaram redução no IAF2, uma vez que ao aplicar doses de 1,2,4 e $8 \mathrm{~kg}^{-h^{-1}}$ de B no sulco de semeadura o IAF2 foi diminuído em $8,16,24$ e $19 \%$, respectivamente.

Nos tratamentos em que foi aplicado $120 \mathrm{~kg} \cdot \mathrm{ha}^{-1}$ de N, apesar da aplicação de boro não ter provocado redução no IAF2 em relação à testemunha $\left(0 \mathrm{~kg} \cdot \mathrm{ha}^{-1} \mathrm{de} \mathrm{B}\right)$, a resposta da variável IAF2 à aplicação de boro em doses crescentes foi pequena, sendo que a dose de $8 \mathrm{~kg} \cdot \mathrm{ha}^{-1}$ de $\mathrm{B}$ no sulco de semeadura proporcionou aumento no IAF2 de apenas $4 \%$.

No entanto, nos tratamentos em que o nitrogênio não foi aplicado $\left(0 \mathrm{~kg} \cdot \mathrm{ha}^{-1} \mathrm{de}\right.$ $\mathrm{N}$ ), verificou-se que a aplicação de boro em doses crescentes no sulco de semeadura proporcionou aumento no IAF2, principalmente para a dose de $8 \mathrm{~kg}_{\mathrm{ha}}{ }^{-1}$ de $\mathrm{B}$, na qual o IAF2 teve acréscimo de $9 \%$ em relação à testemunha $\left(0 \mathrm{~kg} \cdot \mathrm{ha}^{-1} \mathrm{de} \mathrm{B}\right)$.

Assim, na avaliação do IAF2 efetuada 41 dias após a emergência (quando as plantas de milho apresentavam entre 6 e 8 folhas), verificou-se a resposta dessa 
variável à aplicação de boro no sulco de semeadura foi prejudicada pela presença de nitrogênio, sendo que nos tratamentos em que foi aplicada dose elevada de $\mathrm{N}$ (240 kg.ha-1 ${ }^{-1}$, a aplicação de boro no sulco de semeadura provocou redução no IAF2. Uma hipótese para explicar tal resultado pode ser o fato de o nitrogênio ter acelerado o crescimento das plantas nessa fase de desenvolvimento, as quais, conseqüentemente, passaram a absorver maior quantidade de água e nutrientes. Dessa forma, o boro, que estava prontamente disponível para a planta, foi absorvido em excesso pela mesma. Posteriormente os efeitos do boro teriam desaparecido devido à diluição do nutriente na planta proporcionado pelo crescimento da mesma, assim como relatou Ferreira (1997), o qual cita que o crescimento de plantas de milho promovido pela aplicação de doses elevadas de nitrogênio pode resultar em diluição do zinco na planta. Sendo assim, acredita-se que o mesmo pode acontecer para o boro.

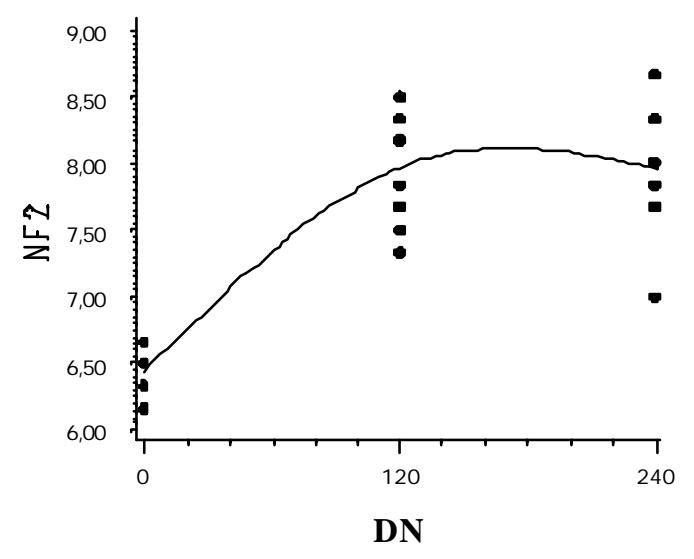

Figura 1 - Número de folhas fotossinteticamente ativas por planta (NF2), determinado aos 41 dias após a emergência, em função da aplicação de doses de nitrogênio (DN, ${\mathrm{kg} . h \mathrm{~h}^{-1}}^{\text {) }}$ 


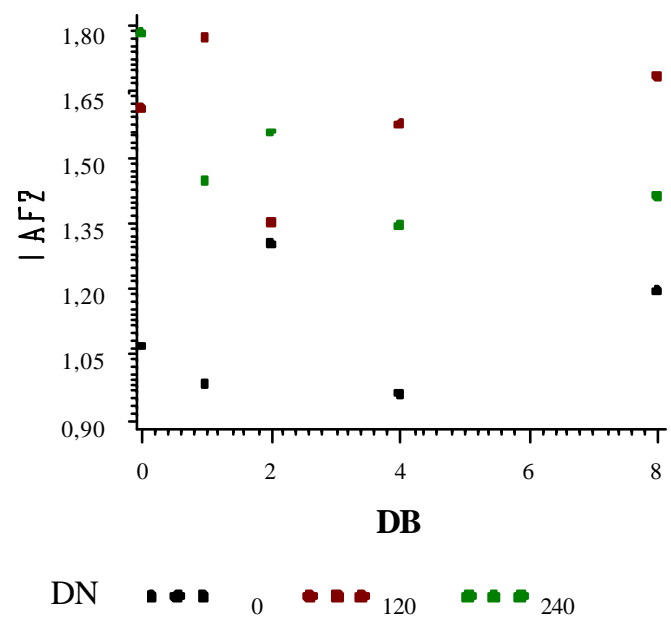

Figura 2 - Índice de área foliar (IAF2), determinado aos 41 dias após a emergência das plantas de milho, em função da aplicação de doses crescentes de boro (DB, $\left.\mathrm{kg} \cdot \mathrm{ha}^{-1}\right)$, para as três diferentes doses de $\mathrm{N}\left(\mathrm{DN}, \mathrm{kg} \cdot \mathrm{ha}^{-1}\right)$

$\mathrm{Na}$ avaliação efetuada aos 49 dias após a emergência das plantas de milho, em que se determinou o NF3 e o IAF3, ao observar os resultados do teste F demonstrados na Tabela 11 e na Tabela 12, ao observar os resultados de nitrogênio proporcionou aumentos significativos tanto do NF3 (nível de significância de 1,2\%) como do IAF3 (nível de significância de 0,5\%), uma vez que a aplicação de $120 \mathrm{~kg}^{-h a^{-1}}$ de $\mathrm{N}$ proporcionou aumento de $16 \%$ e de $46 \%$ no NF3 e no IAF3, respectivamente, conforme demonstrado na Figura e na Figura . No entanto, ao elevar a dose de N de 120 para 240 kg.ha ${ }^{-1}$, não houve acréscimo no valor de NF3 e o IAF3 foi aumentado em apenas 3\%. É importante ressaltar que a correlação de Pearson (Tabela 14) entre as variáseis NF3 e IAF3 foi alta $(0,9074)$.

Tais resultados confirmam praticamente a mesma tendência observada para NF2 e IAF2. Porém, cabe salientar que aos 49 dias após a emergência das plantas (plantas variando entre 11 e 14 folhas) não foi mais constatada influência significativa da aplicação de boro em interação com nitrogênio sobre o IAF3, conforme havia sido observado ao determinar o IAF2 (41 dias após a emergência das plantas), provavelmente devido à uma diluição do boro na planta mediante o crescimento da mesma, conforme 
citado anteriormente. Também não foi observada influência significativa da aplicação de zinco em doses crescentes no sulco de semeadura sobre as variáveis NF3 e IAF3.

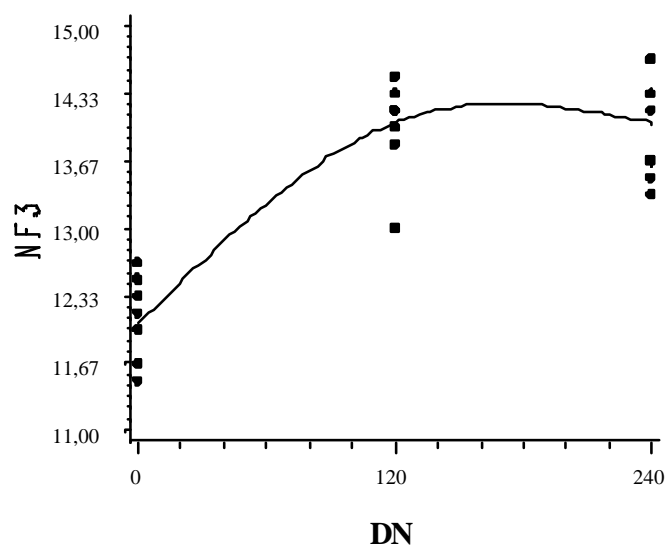

Figura 3 - Número médio de folhas por planta (NF3), determinado aos 49 dias após a emergência, em função da aplicação de doses de nitrogênio (DN, kg.ha ${ }^{-1}$ )

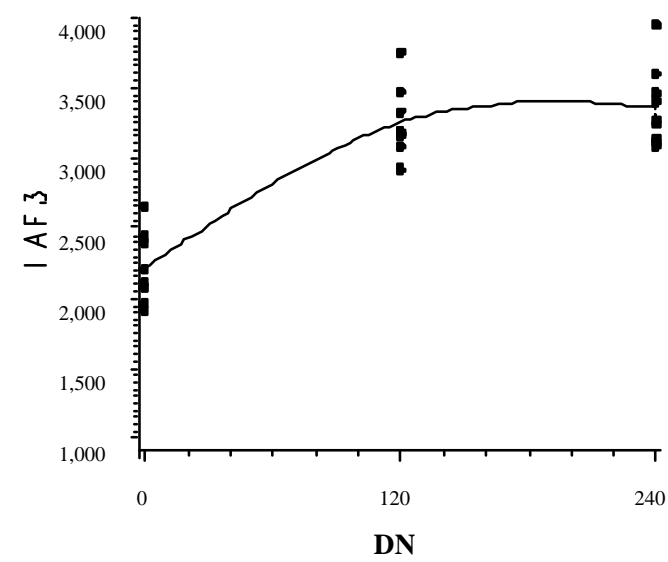

Figura 4 - Índice de área foliar médio (IAF3, m².m²), determinado aos 49 dias após a emergência, em função da aplicação de doses de nitrogênio (DN, kg.ha ${ }^{-1}$ ) Ao observar o resultado do teste $\mathrm{F}$ (Tabela 11), notourse que a variável IAF4, 
determinada no florescimento (65 DAE), foi fortemente influenciada pelas doses crescentes de nitrogênio. Dessa maneira, a aplicação de doses de nitrogênio (DN) proporcionou maior número de folhas fotossintéticamente ativas por planta no florescimento (NF4) e, conseqüentemente, maior índice de área foliar (IAF4) às plantas submetidas à aplicação de 120 e $240 \mathrm{~kg} . h a^{-1}$ de $\mathrm{N}$, quando comparadas às plantas dos tratamentos em que não se efetuou a aplicação de nitrogênio $\left(0 \mathrm{~kg} \cdot \mathrm{ha}^{-1} \mathrm{de} \mathrm{N}\right)$.

Analisando a Tabela 5, nota-se que o NF4 teve um aumento de aproximadamente $11 \%$ quando se ele vou a dose de $\mathrm{N}$ de 0 kg.ha ${ }^{-1}$ (média de 17,83 folhas.planta ${ }^{-1}$ ) para 240 kg.ha ${ }^{-1}$ (média de 19,83 folhas.planta ${ }^{-1}$ ). Também, verificando os resultados da análise de regressão apresentados na Tabela 18 , notourse que houve resposta quadrática do IAF4 para a aplicação de $\mathrm{N}$ em doses crescentes, o qual aumentou de 2,63 para 3,98 (50\%), quando foram adotadas doses de 0 e $120 \mathrm{~kg} \cdot \mathrm{ha}^{-1}$ de $\mathrm{N}$, respectivamente. Ao elevar a dose de $\mathrm{N}$ de 120 para $240 \mathrm{~kg} \cdot \mathrm{ha}^{-1}$, o aumento no IAF4 foi menos significativo (9\%), atingido valor de 4,34 (Figura 5). É valido ressaltar que, de acordo com Andrade et al. (1991), são considerados ideais para a cultura de milho valores de IAF entre 4 e 5 , por ocasião do florescimento.

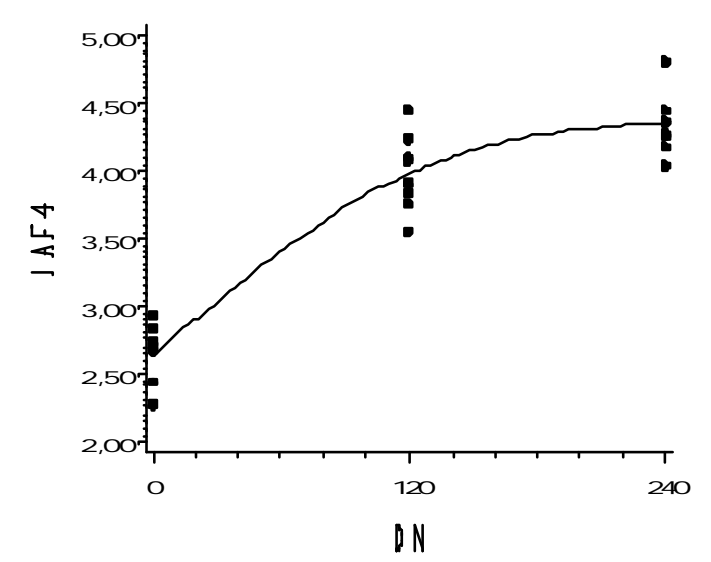

Figura 5 - Índice de área foliar médio no florescimento (IAF4, $\mathrm{m}^{2} \cdot \mathrm{m}^{-2}$ ), determinado aos 65 dias após a emergência, em função da aplicação de doses de nitrogênio (DN, kg.ha ${ }^{-1}$ ) 
Ainda, apesar de não ter sido constatada diferença significativa nos resultados, verificourse que o IAF4 apresentou nível de significância de 6,1\% para a interação entre os elementos nitrogênio e boro, sendo que para a dose de $120 \mathrm{~kg} \cdot \mathrm{ha}^{-1}$ de $\mathrm{N}$ a aplicação de boro proporcionou acréscimo no IAF4, principalmente quando utilizou-se a dose de 4 $\mathrm{kg}_{\mathrm{gha}}{ }^{-1}$ de $\mathrm{B}$, o que pode ser explicado pelo aumento no número de folhas fotossintéticamente ativas por planta (NF4) cujos acréscimos obtidos foram muito similares aos de IAF4. O mesmo não aconteceu ao utilizar a dose de $240 \mathrm{~kg}^{\circ} \mathrm{ha}^{-1}$ de N, onde a adição de boro, pelo contrário, provocou uma redução no IAF4, independentemente da dose utilizada, confirmando os resultados obtidos ao determinar o IAF2, em que a aplicação de boro nos tratamentos com $240 \mathrm{~kg} \cdot \mathrm{ha}^{-1}$ de $\mathrm{N}$ interferiram negativamente no IAF.

Também, conforme demonstrado na Tabela 12, houve influência significativa (nível significância de 4,6\%) da interação entre as doses de $\mathrm{N}$ e as doses de $\mathrm{Zn}$ aplicadas sobre o número de folhas fotossintéticamente ativas por planta, por ocasião do florescimento (NF4) (Tabela 5). Cabe salientar que, apesar do nível de significância apontado pelo teste $\mathrm{F}$ (Tabela 12), não foi possível verificar respostas lineares ou quadráticas (Tabela 20, Figura 6) da variável NF4 para a interação entre as doses de N e de $\mathrm{Zn}$ estudadas, sendo que também não foi possível notar influência significativa do aumento das doses de zinco utilizadas sobre o NF4. 


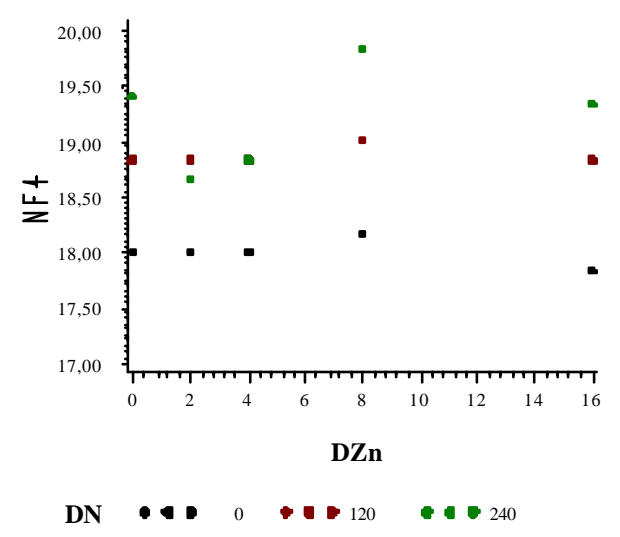

Figura 6 - Número de folhas fotossintéticamente ativas por planta (NF4), determinado aos 65 dias após a emergência das plantas de milho (florescimento), em função da aplicação de doses crescentes de zinco (DZn, kg.ha ${ }^{-1}$ ), para as três diferentes doses de $\mathrm{N}\left(\mathrm{DN}, \mathrm{kg} \cdot \mathrm{ha}^{-1}\right)$

Assim, foi possível concluir que, de maneira geral, as aplicações de boro e de zinco no sulco de semeadura não exerceram influência significativa no número de folhas por planta e no índice de área foliar das plantas de milho, mesmo quando aplicados em doses consideradas elevadas. Concluiu-se também que o nitrogênio exerceu grande influência sobre o número de folhas fotossintéticamente ativas por planta e, conseqüentemente, sobre o índice de área foliar das plantas de milho, uma vez que a aplicação de $\mathrm{N}$ proporcionou aumento significativo no $\mathrm{NF}$ e no IAF em todas as avaliações efetuadas entre a emissão da sexta folha e o florescimento das plantas. É válido ressaltar que os maiores incrementos, tanto no IAF como no NF, foram proporcionados pela aplicação de $120 \mathrm{~kg} \cdot \mathrm{ha}^{-1}$ de $\mathrm{N}$, sendo que a aplicação do dobro da dose (240 kg.ha- ${ }^{-1}$ de $\mathrm{N}$ ) não resultou em acréscimos significativos nos valores obtidos. Estes resultados são importantes pois, de acordo com Fancelli \& Dourado Neto (2000), segundo dados registrados no Corn Belt americano, a produtividade de grãos aumenta significativamente com os incrementos do índice de área foliar da cultura de milho, o qual, normalmente, varia de três a cinco. Cabe salientar ainda que, conforme apresentado na Tabela 14, houve considerável correlação $(0,86)$ entre as variáveis IAF4 
e PROD, mostrando que o índice de área foliar por ocasião do florescimento realmente exerceu influência significativa na produtividade de grãos obtida. Estes resultados confirmam o exposto por Ferreira (1997) que ressalta a importância da área foliar para a obtenção de altas produtividades uma vez que, quanto maior o período que as plantas permanecerem com folhas verdes (fotossintéticamente ativas) e quanto maior a área foliar, maior será a translocação de fotoassimilados para os grãos.

\subsubsection{Altura média da base do pendão e altura média de inserção de espiga}

Os valores apresentados na Tabela 8 mostram que o nitrogênio exerceu grande influência sobre a altura das plantas de milho, pois tanto a altura média da base do pendão (ABP), como a altura média de inserção da espiga (AIE), aumentaram significativamente em função da aplicação de doses crescentes de nitrogênio (DN), o que foi confirmado pelo teste F (Tabela 10 e Tabela 11) o qual mostra que a aplicação de nitrogênio proporcionou influência na $\mathrm{AIE}$ e na $\mathrm{ABP}$ com níveis de significância de $0,006 \%$ e $0,08 \%$, respectivamente.

Nos tratamentos em que a aplicação de nitrogênio não foi efetuada $\left(0 \mathrm{lg}_{\mathrm{g}} \mathrm{ha}^{-1} \mathrm{de}\right.$ $\mathrm{N}$ ), notou-se que a altura média da base do pendão (ABP) foi de $1,86 \mathrm{~m}$, valor $17 \%$ inferior ao obtido nas plantas dos tratamento em que se aplicou $120 \mathrm{~kg} \cdot \mathrm{ha}^{-1}$ de $\mathrm{N}$ (2,17m). Porém, ao dobrar a dose de $\mathrm{N}$ aplicada, ou seja, $240 \mathrm{~kg} \cdot \mathrm{ha}^{-1}$ de $\mathrm{N}$, a resposta não foi significativa, sendo que o aumento na altura média da base do pendão foi de aproximadamente 3\% em relação aos tratamentos com 120 kg.ha ${ }^{-1}$ de N (Figura 7).

Resultados semelhantes foram observados para a variável altura de inserção de espigas (AIE), onde os tratamentos com $120 \mathrm{~kg} \mathrm{ha}^{-1}$ de $\mathrm{N}$ apresentaram valores de AIE $30 \%$ superiores em relação aos tratamentos com 0 kg.ha ${ }^{-1}$ de $\mathrm{N}$, sendo que ao dobrar a dose para $240 \mathrm{~kg} \cdot \mathrm{ha}^{-1}$ de N, o aumento na AIE foi de apenas 3\% (Figura 8).

Os resultados obtidos estão de acordo com Arnon (1975), o qual afirma que plantas mal nutridas com nitrogênio apresentam menor capacidade de assimilar $\mathrm{CO}_{2}$ e de sintetizar carboidratos durante a fotossíntese, resultando em menor acúmulo de biomassa e em retardamento na divisão celular nos pontos de crescimento, o que tem como conseqüência a redução na altura da planta. Sangoi \& Almeida (1994) também 
verificaram aumentos significativos (28\%) na altura das plantas de milho mediante a aplicação de $100 \mathrm{~kg} \cdot \mathrm{ha}^{-1}$ de $\mathrm{N}$, em relação a tratamento em que o N não foi aplicado.

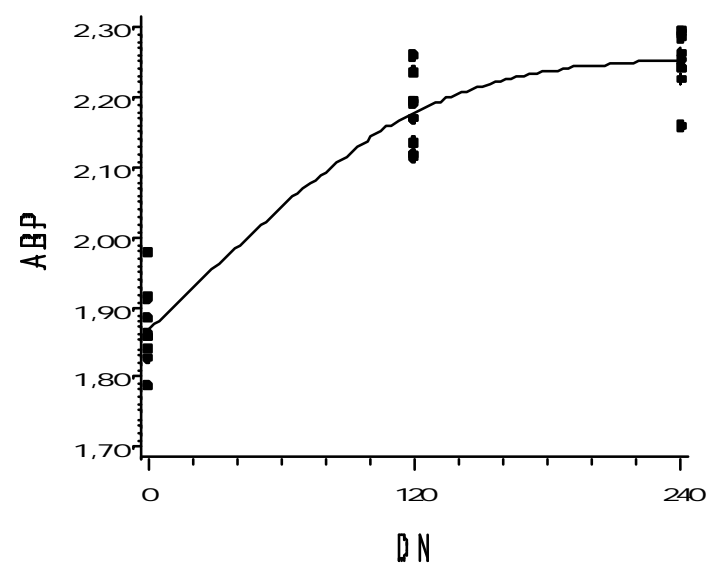

Figura 7 - Altura média da base do pendão $(\mathrm{ABP}, \mathrm{m})$ das plantas de milho em função de doses de nitrogênio (DN, kg.ha ${ }^{-1}$ )

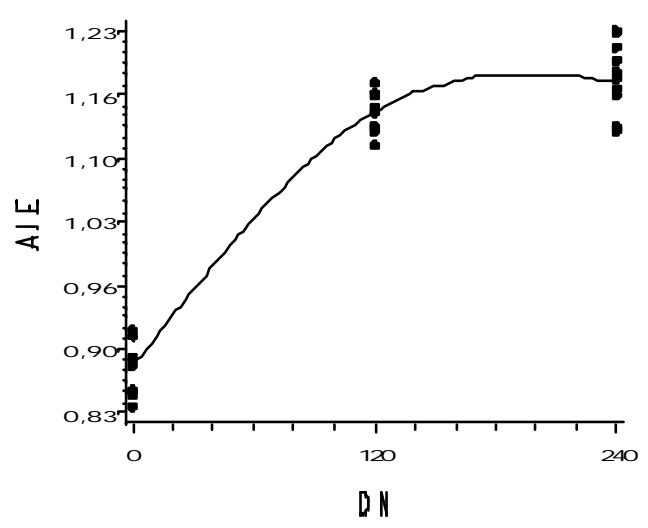

Figura 8 - Altura média da inserção de espiga (AIE, m) das plantas de milho em função de doses de nitrogênio (DN, $\left.\mathrm{kg}_{\mathrm{h}} \mathrm{ha}^{-1}\right)$ 
Quanto aos micronutrientes estudados, Büll (1993) afirma que o zinco tem interferência direta na altura de plantas de milho, pois o referido elemento é necessário à produção de triptofano que é um aminoácido precursor do ácido indol-acético, o qual é um hormônio promotor do crescimento. Assim, de acordo com Furlani \& Furlani (1996), a altura de plantas é a variável que melhor reflete o estresse provocado por baixos níveis de zinco na planta, sendo que, de acordo com Bokert (1989), a deficiência de zinco reduz o crescimento das plantas de milho.

Apesar dessas afirmações, notoutse que as aplicações tanto de zinco como de boro, em doses crescentes no sulco de semeadura de milho, não tiveram influência significativa sobre a altura de inserção de espiga (AIE) e nem sobre a altura de base do pendão (ABP), conforme apresentado na Tabela 10 e na Tabela 11, onde observa-se que o nível de significância é alto (maior que 5\%), em todas as fontes de variação que envolvem os referidos elementos. Dessa maneira, concluiu-se que, nas condições de solo e clima em que foi conduzido o experimento, a aplicação de zinco e de boro no sulco de semeadura, mesmo em altas doses, não exerceu influência significativa na AIE e na $\mathrm{ABP}$ das plantas de milho, ou seja, não proporcionou aumento e nem provocou edução nos valores das variáveis em questão.

É importante salientar que a ausência de respostas das variáveis $\mathrm{AIE}$ e $\mathrm{ABP}$ à aplicação de zinco e de boro no sulco de semeadura pode ter ocorrido devido ao fato de que os níveis dos referidos elementos no solo (Tabela 2) eram satisfatórios para suprir as necessidades da cultura de milho, o que não possibilitou a ocorrência de deficiência nem mesmo na testemunha.

\subsubsection{Diâmetro médio do colmo}

De acordo com Fancelli \& Dourado Neto (2000), o crescimento do colmo das plantas de milho ocorre principalmente a partir da emissão da oitava folha se prolongando até o florescimento, sendo que o colmo não somente atua como suporte de folhas e inflorescências, mas principalmente como uma estrutura destinada ao armazenamento de sólidos solúveis que serão utilizados na formação dos grãos. Desta maneira, assim como a altura da base do pendão, que representa o comprimento do 
colmo, o diâmetro do colmo (DC) das plantas de milho também é muito importante para a obtenção de alta produtividade de grãos, pois quanto maior o DC, maior a capacidade da planta em armazenar fotoassimilados que contribuirão com o enchimento dos grãos.

Ao avaliar os resultados obtidos no experimento, notoutse que o diâmetro do colmo (DC) foi significativamente influenciado pela aplicação de nitrogênio em doses crescentes, conforme verificoutse na Tabela 11 onde se observa que para a fonte de variação $\mathrm{DN}$, o nível de significância foi de $0,5 \%$, o que indica ter havido aumento significativo no DC quando a aplicação de nitrogênio foi efetuada.

Assim, de acordo com os valores médios de diâmetro do colmo apresentados na Tabela 7, a aplicação de $120 \mathrm{~kg} \cdot \mathrm{ha}^{-1}$ de $\mathrm{N}$ proporcionou aumento de aproximadamente $20 \%$ no DC, em relação aos tratamentos onde a aplicação de $\mathrm{N}$ não foi realizada ( 0 $\mathrm{kg} \mathrm{ha}^{-1}$ de N), ou seja, de acordo com o resultado da análise de regressão (Figura 9), o DC passou de 1,89 para 2,27 cm. Porém, ao elevar a dose de nitrogênio aplicada de 120 para $240 \mathrm{~kg}_{\mathrm{ha}}{ }^{-1}$, verificou-se que o resultado foi menos significativo, uma vez que proporcionou aumento no diâmetro médio do colmo das plantas de milho de apenas 4\%, o que demonstra não ser viável o uso de doses de $\mathrm{N}$ muito acima de $120 \mathrm{~kg} \cdot \mathrm{ha}^{-1}$.

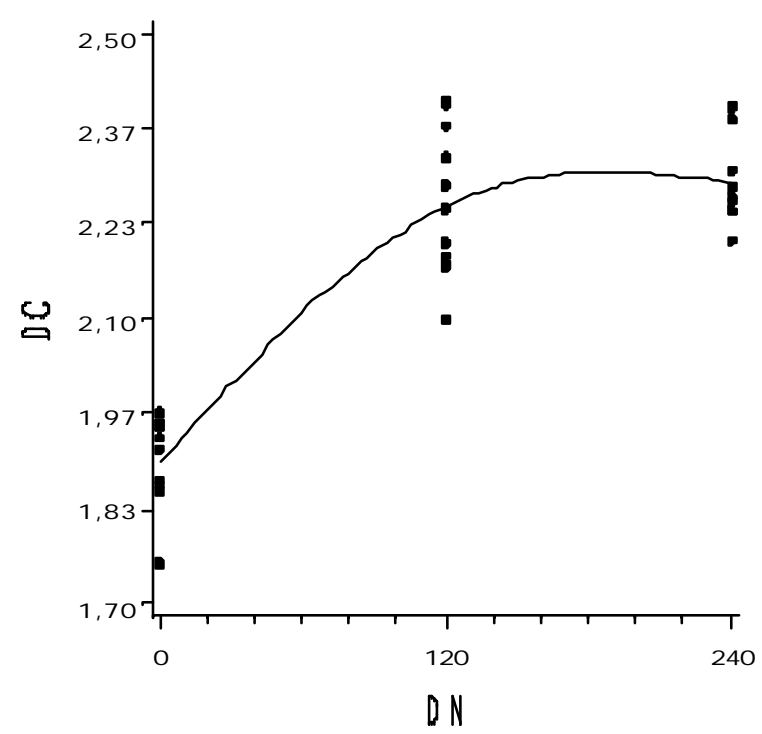

Figura 9 - Diâmetro do colmo de planta de milho (DC, cm) em função de doses de nitrogênio (DN, kg.ha $\left.{ }^{-1}\right)$ 
Com relação aos micronutrientes, ao avaliar os resultados obtidos no teste $\mathrm{F}$ (Tabela 11), notourse que a aplicação de doses crescentes de boro e de zinco no sulco de semeadura não exerceram influência significativa sobre o diâmetro de colmo das plantas de milho, uma vez que o nível de significância foi maior que 5\% para todas as fontes de variação que envolveram os referidos elementos.

\subsubsection{Comprimento médio do primeiro e do segundo internódio do colmo}

Segundo Coelho \& França (1995) o comprimento dos internódios do colmo é a variável que melhor caracteriza a deficiência de zinco nas plantas de milho, uma vez que plantas em que o referido elemento é deficiente, normalmente, apresentam internódios curtos. De acordo com Barbosa Filho (1987), a deficiência de zinco nas plantas provoca o encurtamento dos internódios do colmo resultando em redução do crescimento, o que ocorre devido ao fato de o zinco ser necessário à produção de triptofano que é precursor do ácido indol-acético, um hormônio vegetal promotor do crescimento.

Apesar dessas afirmações, conforme pode ser observado nos valores apresentados na Tabela 8 e nos resultados do teste F (Tabela 10), os tratamentos estudados não exerceram influência significativa sobre o comprimento do primeiro internódio do colmo (COMP_NO1), nem mesmo os tratamentos que incluíam a aplicação de zinco, uma vez que para todas as fontes de variação estudadas os níveis de significância foram maiores do que $5 \%$.

No entanto, verificourse que o comprimento do segundo internódio do colmo (COMP_NO2) foi significativamente influenciado pela aplicação de nitrogênio em doses crescentes (nível de significância de 1\%), uma vez que, conforme apresentado na Figura 10, nos tratamentos em que efetuourse a aplicação de $120 \mathrm{~kg} \cdot \mathrm{ha}^{-1}$ de N, o COMP_NO2 foi aumentado em $27 \%$ (de 7,0 para 8,8 cm), quando comparado aos tratamentos em que o nitrogênio não foi aplicado $\left(0 \mathrm{~kg} \cdot \mathrm{ha}^{-1}\right.$ de $\left.\mathrm{N}\right)$. Observourse também que ao elevar a dose de $\mathrm{N}$ de 120 para $240 \mathrm{~kg} \mathrm{ha}^{-1}$, o aumento no COMP_NO2 foi menos significativo (8\%), o que confirma a baixa resposta da cultura de milho para doses de $\mathrm{N}$ superiores a 120 $\mathrm{kg} \mathrm{ha}^{-1}$. Tais resultados podem ser confirmados ao analisar a Figura 6, em que é possível verificar a resposta da variável comprimento do segundo internódio do colmo 
(COMP_NO2) à aplicação de doses crescentes de nitrogênio (DN).

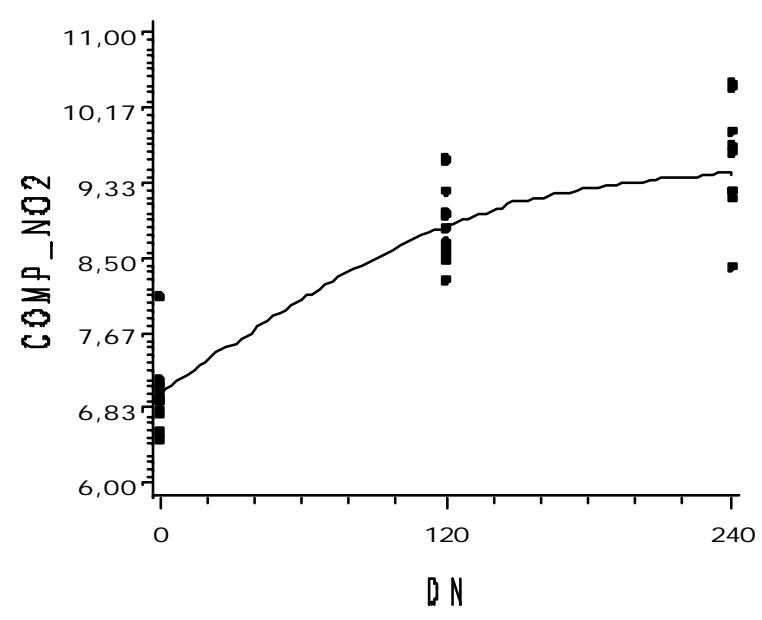

Figura 10 - Comprimento médio do segundo internódio do colmo (COMP_NO2, cm) em função da aplicação de doses de nitrogênio (DN, kg.ha $\left.{ }^{-1}\right)$

Quanto aos elementos boro e zinco, também não se notou influência significativa da aplicação de doses crescentes dos mesmos sobre a variável comprimento do segundo internódio do colmo, uma vez que, de acordo com resultados apresentados na Tabela 10, o nível de significância para todas as fontes de variação que envolvem os referidos micronutrientes foi maior do que $5 \%$.

Dessa maneira, verificourse que, nas condições em que o trabalho foi desenvolvido, a aplicação de $120 \mathrm{~kg} \cdot \mathrm{ha}^{-1}$ de nitrogênio proporcionou o aumento do comprimento do colmo e, conseqüentemente, contribuiu para que as plantas de milho apresentassem maior capacidade de armazenamento de sintetizados. Pôde-se verificar também que os elementos boro e zinco, aplicados no sulco de semeadura de milho em doses de até $8 \mathrm{~kg} \cdot \mathrm{ha}^{-1}$ e $16 \mathrm{~kg} \cdot \mathrm{ha}^{-1}$, respectivamente, não alteraram o desenvolvimento e crescimento do colmo. 


\subsubsection{Massa média de matéria seca de folha, colmo, pendão e espiga}

De acordo com os resultados do teste $\mathrm{F}$ apresentados na Tabela 13, tanto a aplicação de nitrogênio, como a aplicação de zinco, em doses crescentes, exerceram influência significativa sobre a massa de matéria seca de colmo (MMSC) e sobre a massa de matéria seca de folha (MMSF), conforme demonstrado na Figura 11 e na Figura 12, respectivamente. Também, analisando a Tabela 16 foi possível verificar que houve considerável correlação $(0,81)$ entre as variáveis MMSF e MMSC.

Ao analisar os valores médios obtidos (Tabela 7), notoutse que a aplicação de 120 kg.ha ${ }^{-1}$ de N proporcionou aumento de aproximadamente $65 \%$ e $30 \%$ na MMSC e na MMSF, respectivamente, em relação aos tratamentos onde a aplicação de $\mathrm{N}$ não foi efetuada $\left(0 \mathrm{~kg} \cdot \mathrm{ha}^{-1} \mathrm{de} \mathrm{N}\right)$. Porém, quando as doses de $\mathrm{N}$ foram aumentadas de 120 para $240 \mathrm{~kg} \cdot \mathrm{ha}^{-1}$ de $\mathrm{N}$, verificourse que o aumento na MMSC e na MMSF não foi significativo.

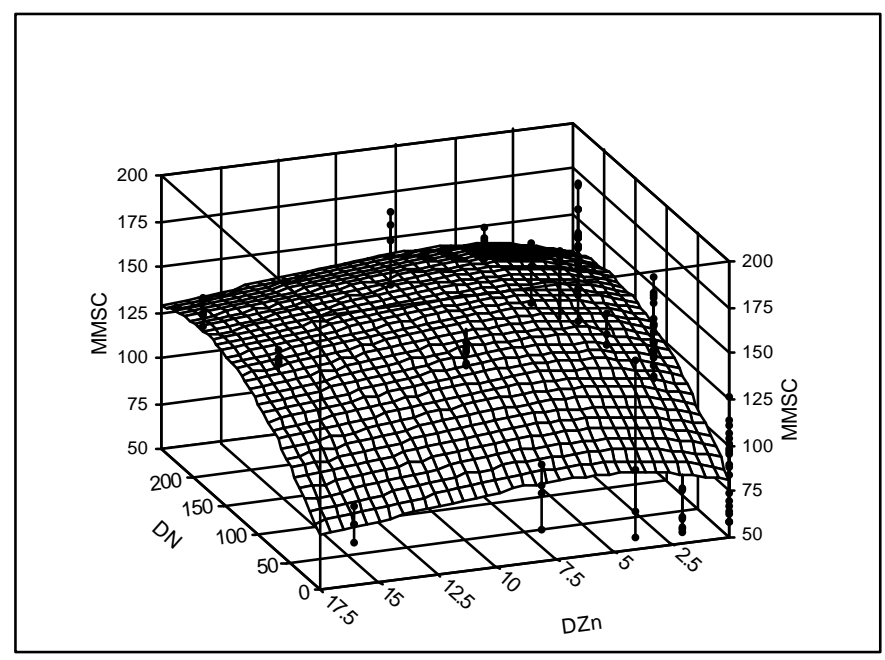

Figura 11 - Massa de matéria seca de colmo (MMSC, g.planta ${ }^{-1}$ ), em função da aplicação de doses de nitrogênio (DN, kg.ha $\left.{ }^{-1}\right)$ e de zinco (DZn, kg.ha ${ }^{-1}$ ) 


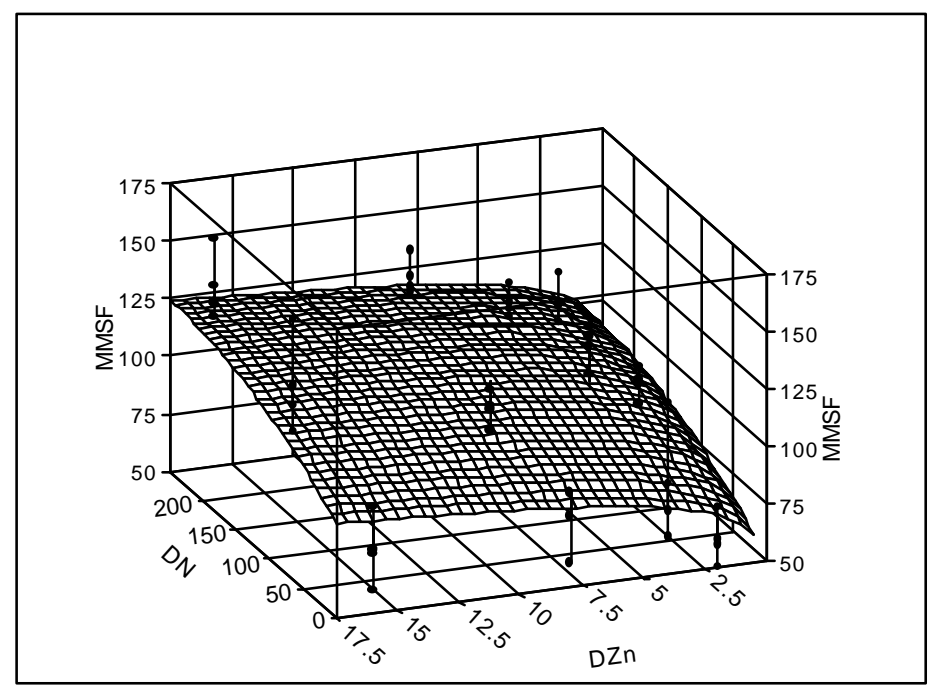

Figura 12 - Massa de matéria seca de folha (MMSF, g.planta ${ }^{-1}$ ), em função da aplicação de doses de nitrogênio (DN, kg.ha ${ }^{-1}$ ) e de zinco (DZn, kg.ha ${ }^{-1}$ )

Observou-se ainda que, apesar de não terem havido respostas significativas da altura da base do pendão (comprimento do colmo), da altura de inserção de espigas, do diâmetro do colmo e do índice de área foliar (determinados por ocasião do florescimento) à aplicação de doses crescentes de zinco, foram verificadas respostas tanto da MMSC, como da MMSF, quando doses de zinco foram aplicadas no sulco de semeadura.

Dessa maneira, ao analisar a Figura 11, notou-se que os máximos valores de massa de matéria seca de colmo foram atingidos com a aplicação de $8 \mathrm{~kg} \mathrm{ha}^{-1}$ de $\mathrm{Zn}$, havendo um decréscimo nos valores de MMSC quando doses maiores (16 kg.ha $\left.{ }^{-1}\right)$ do elemento foram aplicadas. Verificou-se também que a aplicação de zinco proporcionou efeito positivo sobre a massa de matéria seca de folhas, uma vez que o quanto maior a dose de $\mathrm{Zn}$ aplicada, maior foi o valor de MMSF obtido, sendo registrados acréscimos até para a dose de 16 kg.ha-1 de Zn (Figura 12).

Com relação à massa de matéria seca de espiga (MMSE), na Figura 13 foi observado que quanto maior a dose de nitrogênio aplicada, maior foi a MMSE obtida. Assim, em relação aos tratamentos em que o nitrogênio não foi aplicado $\left(0 \mathrm{~kg} \cdot \mathrm{ha}^{-1} \mathrm{de}\right.$ $\mathrm{N}$ ), verificou-se que a MMSE teve um aumento de aproximadamente 50\% quando se 
aplicou dose de $120 \mathrm{~kg} \cdot \mathrm{ha}^{-1}$ de N. No entanto, ao aumentar a dose de $\mathrm{N}$ de $120 \mathrm{~kg}^{-h^{-1}}$ para $240 \mathrm{~kg} \cdot \mathrm{ha}^{-1}$, notourse que a resposta foi menos expressiva, proporcionando aumento de aproximadamente 10\% na MMSE. Cabe salientar que, conforme apresentado na Tabela 13, tanto a aplicação de zinco como de boro, em doses crescentes no sulco de semeadura, não exerceram influência significativa sobre a MMSE.

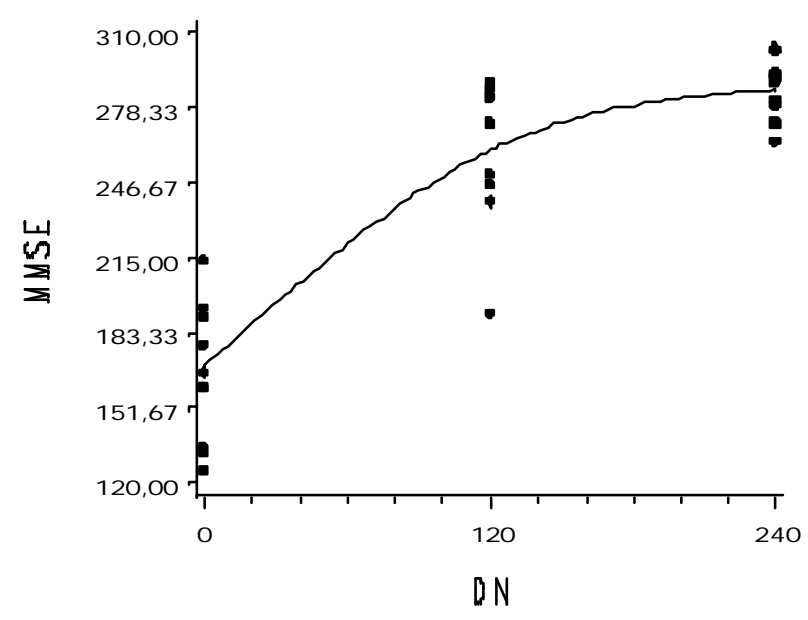

Figura 13 - Massa de matéria seca de espiga (MMSE, g.planta ${ }^{-1}$ ) em função da aplicação de doses de nitrogênio (DN, kg.ha $\left.{ }^{-1}\right)$

Mediante os resultados obtidos, pode-se afirmar que aplicações de doses de nitrogênio acima de $120 \mathrm{~kg}_{\mathrm{ha}}{ }^{-1}$ não contribuem significativamente para o aumento na massa de matéria seca de colmo, de folhas e de espigas.

Quanto à massa de matéria seca de pendão, de acordo com o apresentado na Tabela 13, nenhum dos tratamentos estudados exerceram influência significativa sobre a referida variável, uma vez que para todas as fontes de variação o nível de significância foi superior a $5 \%$. 


\subsubsection{Componentes de produção}

\subsubsection{Prolificidade}

O termo prolificidade é utilizado para designar o número de espigas por planta, o qual pode ser influenciado pela característica genética do híbrido, pela população de plantas utilizada, pelas condições climáticas do local e pela disponibilidade de nutrientes.

Conforme pode ser observado na Tabela 12, o número de espigas por planta (PROLIF) sofreu influência significativa apenas da fonte de variação $\mathrm{N}$ (nível de significância de 0,004\%), sendo que para as demais fontes avaliadas obteve-se nível de significância maior que 5\%, o que indica que não houve influência significativa da aplicação de boro e zinco, em doses crescentes, sobre a prolificidade do híbrido estudado.

Dessa maneira, de acordo com o exposto na Figura 14, a aplicação de doses crescentes de nitrogênio $(\mathrm{DN})$ proporcionou um acréscimo no número de espigas por planta (PROLIF), sendo que, em relação aos tratamentos em que não se efetuou a aplicação de nitrogênio $\left(0 \mathrm{~kg} \cdot \mathrm{ha}^{-1}\right.$ de $\left.\mathrm{N}\right)$, a aplicação de doses de $120 \mathrm{~kg}^{-h a^{-1}}$ de $\mathrm{N}$ promoveu aumento médio de 1,07 para 1,29 espigas por planta, o que representa acréscimo de $20 \%$. No entanto, ao elevar a dose de $\mathrm{N}$ de 120 para $240 \mathrm{~kg}^{\circ} \mathrm{ha}^{-1}$, verificouse que a diferença obtida na PROLIF, não foi significativa, uma vez que o aumento proporcionado foi de apenas $0,21 \%$.

Estes resultados estão de acordo com Ferreira (1997) que também observou aumento significativo do número de espigas por planta de milho ao efetuar a aplicação de doses crescentes de nitrogênio.

Também, ao contrário do que se esperava, o coeficiente de correlação entre s variáveis prolificidade (PROLIF) e produtividade (PROD) foi relativamente baixo $(0,78)$, de acordo com o observado na Tabela 15 . 


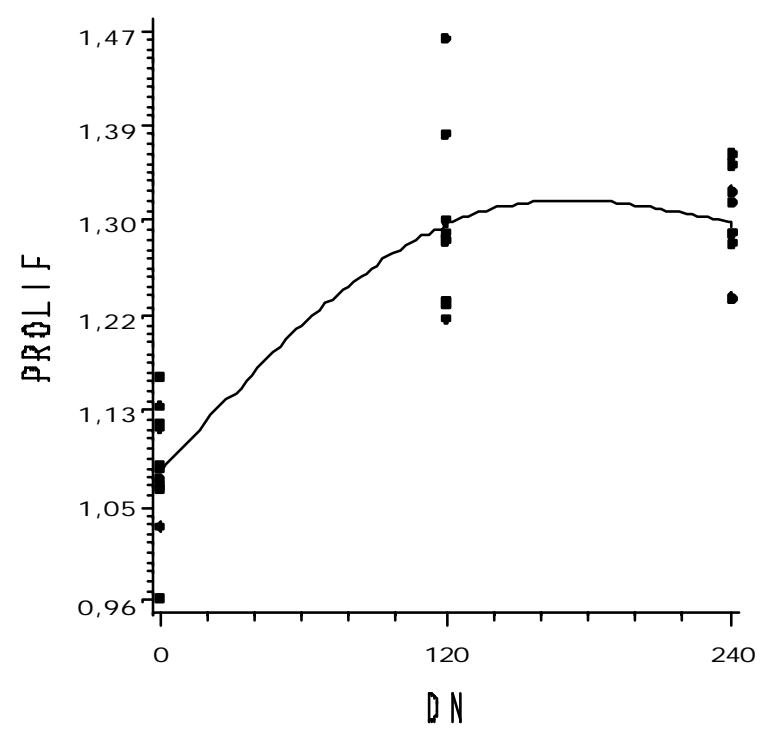

Figura 14 - Prolificidade (PROLIF) das plantas de milho em função de doses de nitrogênio (DN, kg.ha $\left.{ }^{-1}\right)$

\subsubsection{Comprimento médio da espiga}

O comprimento médio da espiga (COMPESP) é uma das variáveis que pode interferir diretamente no número de grãos por fileira e, conseqüientemente, na produtividade da cultura de milho. Segundo Fancelli (1986), o comprimento das espigas na cultura de milho é definido, principalmente, no momento em que as plantas apresentam 12 folhas plenamente expandidas (estádio 3). Sendo assim, qualquer adversidade que aconteça nessa fase, como disponibilidade inadequada de nutrientes (falta ou excesso), pode resultar em redução no comprimento das espigas e, como consequiência, provocar queda na produtividade.

De acordo com os resultados apresentados na Tabela 9, pode-se observar que houve um aumento significativo no comprimento médio das espigas de milho em função da aplicação de nitrogênio em doses crescentes, uma vez que o referido elemento exerceu forte influência sobre o COMPESP, conforme pode ser constatado na Tabela 10 que mostra nível de significância menor que 0,00001 para a fonte de variação DN. Assim, conforme apresentado na Figura , a aplicação de $120 \mathrm{~kg} \cdot \mathrm{ha}^{-1}$ de N proporcionou 
aumento médio de $22 \%$ no comprimento das espigas em relação aos tratamentos em que a aplicação de $\mathrm{N}$ foi ausente $\left(0 \mathrm{~kg} \cdot \mathrm{ha}^{-1} \mathrm{de} \mathrm{N}\right)$. No entanto, ao elevar as doses de $\mathrm{N}$ de 120 kg.ha ${ }^{-1}$ para $240 \mathrm{~kg} \cdot \mathrm{ha}^{-1}$, o aumento foi pouco expressivo (3\%).

Cabe destacar que os resultados obtidos estão de acordo com o relatado por Büll (1993) que coloca que a aplicação de nitrogênio proporciona elevação de produtividade na cultura de milho, a qual pode ser atribuída, dentre outros fatores, aos efeitos positivos do referido elemento sobre o aumento do comprimento da espiga.

Quanto aos elementos boro e zinco, não se notou influência significativa da aplicação de doses crescentes dos mesmos sobre a variável comprimento de espiga. Tal resultado pode ter sido obtido pelo fato de o solo apresentar teores suficientes de boro $\left(0,35 \mathrm{mg} \cdot \mathrm{dm}^{-3}\right)$ e de zinco $\left(2,0 \mathrm{mg} \cdot \mathrm{dm}^{-3}\right)$ para suprir as necessidades da cultura de milho, não permitindo o aparecimento de sintomas de deficiência mesmo na ausência de aplicação dos mesmos. É valido lembrar que Fancelli \& Dourado Neto (2000) colocam como ideais para a cultura de milho, teores de boro entre 0,1 e $0,3 \mathrm{mg} \cdot \mathrm{dm}^{-3}$ e de zinco entre 0,5 e $1,0 \mathrm{mg} \cdot \mathrm{dm}^{-3}$. No entanto é importante destacar também que as altas doses de boro e de zinco aplicadas no sulco de semeadura $\left(8 \mathrm{~kg} \mathrm{ha}^{-1}\right.$ e 16 kg.ha ${ }^{-1}$, respectivamente) não interferiram negativamente sobre o comprimento das espigas de milho.

Ainda, cabe salientar que o comprimento de espiga (COMPESP) foi a variável que mais contribuiu para o aumento de produtividade de grãos (PROD), uma vez que de acordo com o exposto na Tabela 17, o coeficiente de correlação de Pearson entre as referidas variáveis foi de 0,9076, sendo esse o valor mais alto de correlação obtido entre as variáveis estudadas. O COMPESP também apresentou relativa correlação $(0,7999)$ com o número de grãos por fileira (NGF) o que pode explicar a contribuição da variável para o aumento da produtividade. 


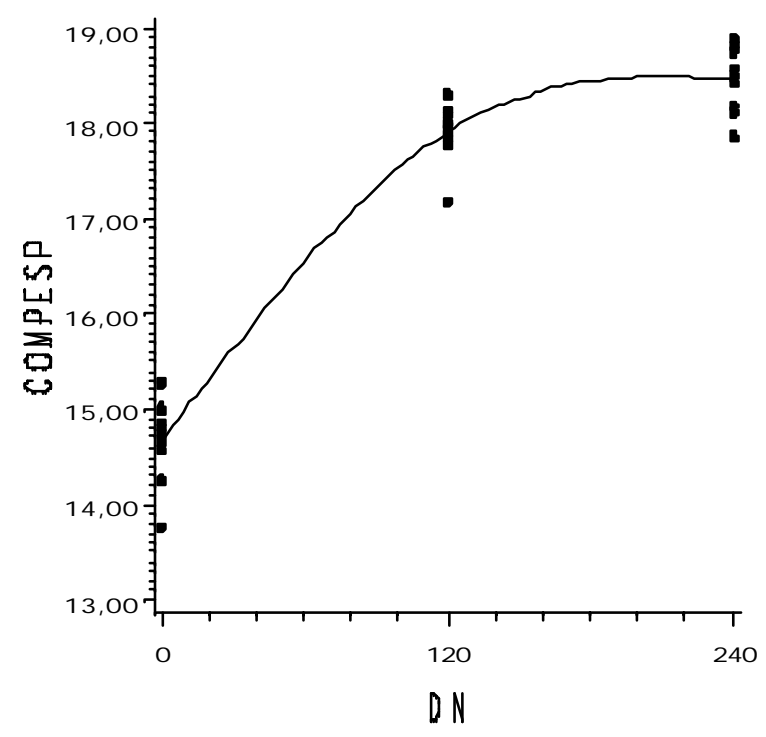

Figura 15 - Comprimento médio de espigas de milho (COMPESP, cm) em função de doses de nitrogênio (DN, kg.ha-1)

\subsubsection{Número médio de grãos por fileira da espiga}

Conforme resultados apresentados na Tabela 9, a aplicação de nitrogênio em doses crescentes exerceu grande influência no número de grãos por fileira (NGF), uma vez que proporcionou aumento significativo nos valores obtidos. Nos tratamentos em que se efetuou a aplicação de $120 \mathrm{~kg} \cdot \mathrm{ha}^{-1}$ de $\mathrm{N}$, o NGF foi aumentado em aproximadamente $25 \%$, quando comparado aos ratamentos em que o nitrogênio não foi aplicado $\left(0 \mathrm{~kg} \cdot \mathrm{ha}^{-1}\right.$ de $\left.\mathrm{N}\right)$. Ao elevar a dose de $\mathrm{N}$ de 120 para $240 \mathrm{~kg}^{\circ} \cdot \mathrm{ha}^{-1}$, observou-se que o aumento no número de fileiras de grãos na espiga foi menos significativo, em torno de $2 \%$. Tais resultados podem ser confirmados ao analisar os valores do teste $\mathrm{F}$, apresentados na Tabela 12, em que o nível de significância para a fonte de variação DN foi de $0,06 \%$. 


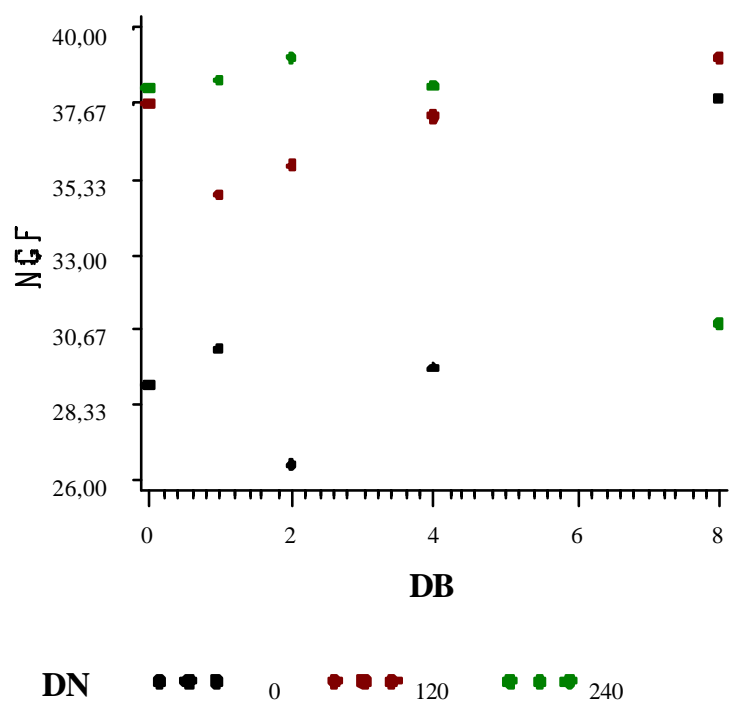

Figura 16 - Número médio de grãos por fileira (NGF), em função da aplicação de doses crescentes de B e de N. (kg.ha $\left.{ }^{-1}\right)$

Também na Tabela 12 notou-se que o valor do nível de significância para a fonte de variação DNxDB foi de 0,007\% para a variável número de grãos por fileira (NGF), o que demonstra ter existido certa influência da interação de nitrogênio com boro sobre o NGF. Tal afirmação foi confirmada ao observar a análise de regressão apresentada na Tabela 19, onde nota-se que houve resposta quadrática da variável NGF (nível de significância menor que 5,0\%) para a interação entre as doses de boro e todas as doses de nitrogênio estudadas.

Ao analisar a Figura 16, verificou-se que nos tratamentos em que o nitrogênio não foi aplicado (0 kg.ha ${ }^{-1}$ de $\left.\mathrm{N}\right)$ a adição de boro no sulco de semeadura somente proporcionou aumento significativo mediante aplicação de $8 \mathrm{~kg}^{-h^{-1}}$ de $\mathrm{B}$, sendo que a aplicação da referida dose proporcionou aumento de 30\% no NGF, em relação aos demais tratamentos $\left(0,1,2\right.$ e $4 \mathrm{~kg} \cdot \mathrm{ha}^{-1}$ de B).

Quando se utilizou a dose de $120 \mathrm{~kg} \cdot \mathrm{ha}^{-1}$ de $\mathrm{N}$, os resultados obtidos foram semelhantes, uma vez que apenas a aplicação de $8 \mathrm{~kg}$ ha ${ }^{-1}$ de boro no sulco de semeadura proporcionou respostas significativas. Porém, cabe salientar que para essa 
dose de N, o aumento do NGF proporcionado pela referida dose de boro foi menor do que quando o $\mathrm{N}$ não foi aplicado, ou seja, de apenas 8,8\%. Assim, é importante ressaltar que a aplicação de $120 \mathrm{~kg} \cdot \mathrm{ha}^{-1}$ de $\mathrm{N}$ reduziu a influência da aplicação de boro sobre o NGF.

Nos tratamentos em que foram aplicados $240 \mathrm{~kg} \cdot \mathrm{ha}^{-1}$ de N, a aplicação de boro no sulco de semeadura, em doses crescentes, também não provocou alterações significativas do número de grãos por fileira para doses de até $4 \mathrm{~kg} \mathrm{ha}^{-1}$ de B. Porém, observou-se que no tratamento em que a referida dose de $\mathrm{N}$ foi aplicada, a aplicação de 8 kg.ha ${ }^{-1}$ de B provocou significativa redução (19\%) no NGF.

Desta maneira, os resultados obtidos levam a concluir que o NGF foi influenciado significativamente pelo boro quando o referido elemento foi aplicado em alta dose no sulco de semeadura $\left(8 \mathrm{~kg} \cdot \mathrm{ha}^{-1}\right)$. Porém, tal influência variou de acordo com a dose de nitrogênio aplicada, uma vez que, quanto maior a dose de $\mathrm{N}$, menores foram os efeitos benéficos do boro sobre o NGF. É importante destacar que ao utilizar alta dose de N (240 kg.ha ${ }^{-1}$ ) os efeitos da aplicação de alta dose de boro sobre o NGF passaram a ser negativos, ou seja, ao aplicar $240 \mathrm{~kg} \cdot \mathrm{ha}^{-1}$ de $\mathrm{N}$, a aplicação $8 \mathrm{~kg}^{-h a^{-1}}$ de B provocou queda no número de grão por fileira das espigas de milho.

Ainda, de acordo com o resultado do teste F (Tabela 12), o número de grãos por fileira da espiga não foi influenciado significativamente pela aplicação de zinco no sulco de semeadura, nem mesmo quando utilizou-se doses elevadas (16 kg.ha ${ }^{-1}$ de $\mathrm{Zn}$ ). Tal resultado mostra que, para solos argilosos, como o solo em que este experimento foi conduzido, a aplicação de doses de até $16 \mathrm{~kg} . h a^{-1}$ de $\mathrm{Zn}$ no sulco de semeadura, mediante o uso de sulfato de zinco como fonte, não provocou efeitos negativos sobre o NGF das espigas de milho.

A variável que apresentou maior correlação com o número de grãos por fileira (NGF) foi o comprimento de espiga (COMPESP), uma vez que de acordo com os valores apresentados na Tabela 17, o coeficiente de correlação de Pearson entre as referidas variáveis foi de 0,7999. Esse resultado está de acordo com Fancelli (1986) o qual cita que o número médio de grãos por fileira é afetado pelo tamanho da espiga. Assim, pode-se reafirmar a conclusão de que houve certa influência do comprimento das 
espigas sobre o número de grãos por fileira e, conseqüentemente, sobre a produtividade de grãos.

\subsubsection{Numero médio de fileiras de grãos da espiga}

Ao observar os resultados do teste $\mathrm{F}$ para a variável número de fileiras de grãos da espiga (NFG), apresentados na Tabela 12, verificou-se que, para todas as fontes de variação estudadas, o nível de significância foi muito superior a 5\%. Esse resultado indica que, nas condições em que o trabalho foi desenvolvido, não houveram influências significativas tanto do nitrogênio, como do boro e do zinco, aplicados em doses crescentes, sobre o número de fileiras de grãos da espiga, uma vez que, conforme demonstrado na Tabela 9, as espigas pertencentes a todos os tratamentos estudados apresentaram uma média de aproximadamente 14 fileiras de grãos.

Ainda, de acordo com o exposto na Tabela 17, a variável NFG não apresentou alta correlação com nenhuma das variáveis estudadas.

\subsubsection{Comprimento médio dos grãos}

O comprimento médio dos grãos (COMPGRAO), determinado a partir da diferença entre o diâmetro médio da espiga e o diâmetro médio do sabugo, não foi influenciado significativamente pela aplicação de doses crescentes de nitrogênio, zinco e boro, conforme resultados do teste $\mathrm{F}$ apresentados na Tabela 10, onde observou-se que para todas as fontes de variação, o nível de significância foi superior a 5\%. Cabe salientar também que, de acordo com a Tabela 17, a variável COMPGRAO não apresentou alta correlação com nenhuma das variáveis estudadas.

\subsubsection{Massa de mil grãos}

A massa de mil grãos (M1000G) é considerada um importante componente de produtividade de grãos, uma vez que, após o florescimento, qualquer tipo de estresse a que a planta seja submetida, de natureza biótica ou abiótica, poderá afetá-lo significativamente (Fancelli \& Dourado Neto, 2000). Assim, a deficiência ou a fitotoxidez provocada por algum elemento, como boro, zinco ou nitrogênio por exemplo, poderá reduzir a massa de grãos das plantas de milho. 
Ao observar os resultados do teste $\mathrm{F}$ apresentados na Tabela 13, verificou-se que a variável M1000G foi influenciada significativamente (nível de significância de 4,7\%) pela interação entre os elementos nitrogênio e zinco aplicados, porém, de acordo com o apresentado na Tabela 20, não houve resposta linear ou quadrática da referida variável à aplicação dos referidos elementos.

Ao efetuar a regressão dos resultados apresentados na Figura, observou-se que nos tratamentos em que a aplicação de nitrogênio não foi realizada $\left(0 \mathrm{~kg} \cdot \mathrm{ha}^{-1} \mathrm{de} \mathrm{N}\right)$, houve um aumento da M1000G mediante a aplicação de doses crescentes de zinco, sendo que a maior resposta foi obtida quando aplicourse a dose $16 \mathrm{~kg}_{\mathrm{ha}}{ }^{-1} \mathrm{de} \mathrm{Zn}$, a qual proporcionou aumento de 9,5\% na M1000G, em relação à testemunha $\left(0\right.$ kg.ha ${ }^{-1}$ de Zn). Para essa dose, a M1000G atingiu valor médio de 238,5g.

Também pela análise de regressão dos resultados apresentados na Figura 17, notou-se que quando foi realizada a aplicação de $120 \mathrm{~kg}$ ha ${ }^{-1}$ de $\mathrm{N}$, não houve resposta significativa da M1000G para dose de até $8 \mathrm{~kg} \mathrm{ha}^{-1}$ de $\mathrm{Zn}$ aplicada no sulco de semeadura, porém, ao aumentar a dose de $\mathrm{Zn}$ para $16 \mathrm{~kg} \mathrm{ha}^{-1}$ houve redução de $8 \%$ no valor da massa de mil grãos obtido $(220,23 \mathrm{~g})$, em relação ao tratamento sem adição de zinco $(239,42 \mathrm{~g})$. Nesse caso, é importante salientar que no tratamento em que efetuou-se a aplicação de $120 \mathrm{~kg} \cdot \mathrm{ha}^{-1}$ de $\mathrm{N}$ e de $16 \mathrm{~kg} \cdot \mathrm{ha}^{-1}$ de $\mathrm{Zn}$, o valor obtido de M1000G $(220,23 \mathrm{~g})$ foi $8,3 \%$ menor do que no tratamento em que também aplicou-se $16 \mathrm{~kg} \cdot \mathrm{ha}^{-1} \mathrm{de}$ $\mathrm{Zn}$ porém o $\mathrm{N}$ não foi aplicado $(238,58 \mathrm{~g})$.

O mesmo não foi observado quando foi aplicado $240 \mathrm{~kg}^{-h a^{-1}}$ de $\mathrm{N}$, sendo que nesse caso, a M1000G não diferiu significativamente de acordo com a dose de zinco aplicada. 


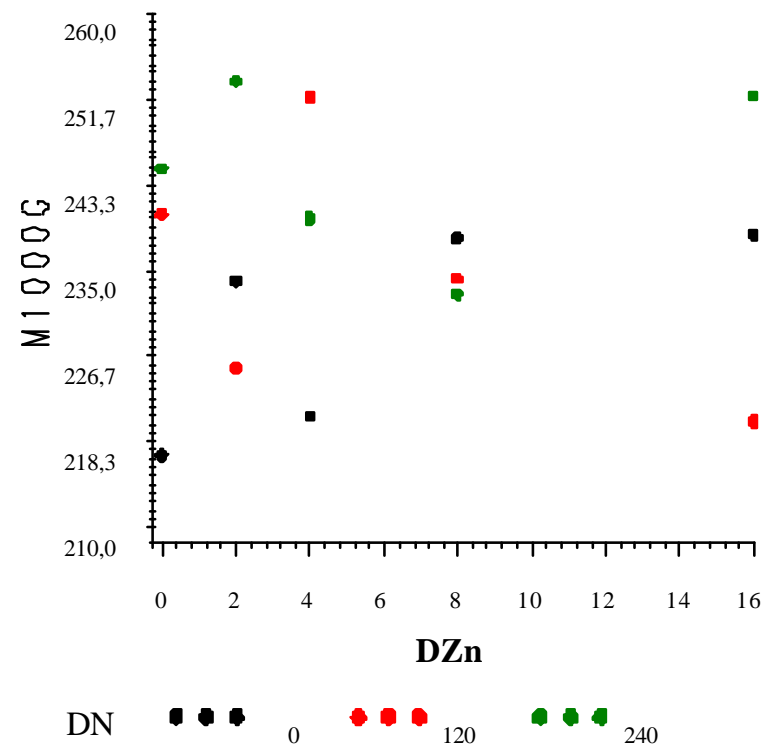

Figura 17 - Massa de mil grãos (M1000G, g) em função da aplicação de doses crescentes de zinco (DZn, kg.ha ${ }^{-1}$ ), para as três diferentes doses de N (DN, $\mathrm{kg}_{\mathrm{ha}}{ }^{-1}$ )

De acordo com o demonstrado pelo teste F (Tabela 13), a aplicação de boro em doses crescentes (DN) e a aplicação de boro juntamente com nitrogênio (DNxDB) não exerceram influência significativa sobre a variável massa de mil grãos, pois o nível de significância para as referidas variáveis foi maior que $5 \%$.

Ainda, cabe salientar que não foram observadas diferenças na M1000G para a fonte de variação $\mathrm{DN}$, o que demonstra não ter havido influência significativa das doses crescentes de $\mathrm{N}$ sobre a massa de mil grãos. Tais resultados diferiram dos reportados por Ferreira (1997), que observou aumento de $24,5 \%$ na massa de mil grãos de milho ao aplicar dose de $210 \mathrm{~kg} \cdot \mathrm{ha}^{-1}$ de N. Também, Sangoi \& Almeida (1994), ao efetuarem um experimento em que aplicaram nitrogênio em doses crescentes, verificaram efeito linear da adubação nitrogenada sobre a massa de mil grãos de milho, sendo que a aplicação de $150 \mathrm{~kg} \cdot \mathrm{ha}^{-1}$ de $\mathrm{N}$ proporcionou aumento de $7 \%$ em relação à testemunha $\left(0 \mathrm{~kg} \cdot \mathrm{ha}^{-1} \mathrm{de}\right.$ $\mathrm{N})$. Os referidos autores destacaram que o aumento na massa de mil grãos pode ter sido conseguido devido ao fato de que as maiores doses de nitrogênio mantiveram a atividade 
fotossintética por um período mais prolongado, o que resultou no maior acúmulo de carboidratos nos grãos.

\subsubsection{Produtividade}

Os resultados obtidos mostraram claramente a importância do nitrogênio para o aumento da produtividade (PROD) na cultura de milho, uma vez que o referido elemento teve influência significativa (nível de significância menor que 0,001\%) sobre a referida variável.

Observando a Tabela 9 verificourse que a aplicação de $120 \mathrm{~kg} \mathrm{ha}^{-1}$ de nitrogênio proporcionou aumento de $92 \%$ na produtividade em relação aos tratamentos onde a aplicação de nitrogênio não foi efetuada $\left(0 \mathrm{~kg}_{\mathrm{hah}}{ }^{-1}\right.$ de $\left.\mathrm{N}\right)$, ou seja, analisando a estimativa do modelo de regressão polinomial da Figura 18 (Tabela 18), notou-se que quando a aplicação de $\mathrm{N}$ foi nula a produtividade obtida foi de $4354,7 \mathrm{~kg} \cdot \mathrm{ha}^{-1}$, ao passo que quando aplicourse $120 \mathrm{~kg} \cdot \mathrm{ha}^{-1}$ de N, obteve-se $8379,9 \mathrm{~kg} \cdot \mathrm{ha}^{-1}$ de grãos.

Ao avaliar os resultados obtidos nos tratamentos com 120 e $240 \mathrm{~kg}^{-h^{-1}}$ de N, notou-se que o aumento na produtividade proporcionado pela elevação nas doses de nitrogênio foi menos significativo, sendo que para a dose de $240 \mathrm{~kg}^{-h a^{-1}}$ de $\mathrm{N}$ a produtividade obtida foi de $9017,7 \mathrm{~kg} \cdot \mathrm{ha}^{-1}$ de grãos, o que indica aumento de apenas $7,6 \%$ em relação aos tratamentos em que foi aplicado $120 \mathrm{~kg} \cdot \mathrm{ha}^{-1}$ de N. Também, através da análise de regressão da curva de resposta quadrática, observou-se que a produtividade máxima foi obtida com a dose de 202,6 kg.ha-1 de $\mathrm{N}$, na qual foram produzidos 9182,2 kg.ha-1 de grãos, o que equivale a um aumento de $108 \%$ e $9 \%$ em relação à produtividade obtida com 0 kg.ha ${ }^{-1}$ e $120 \mathrm{~kg} \cdot \mathrm{ha}^{-1}$ de $\mathrm{N}$, respectivamente. Dessa maneira, esse resultado demonstra que, para as condições em que o experimento foi conduzido, não seria viável o uso de doses de $\mathrm{N}$ muito superiores a $120 \mathrm{~kg} \cdot \mathrm{ha}^{-1}$ pois o benefício obtido não seria suficiente para suprir o gasto relativo ao aumento da dose de N. 


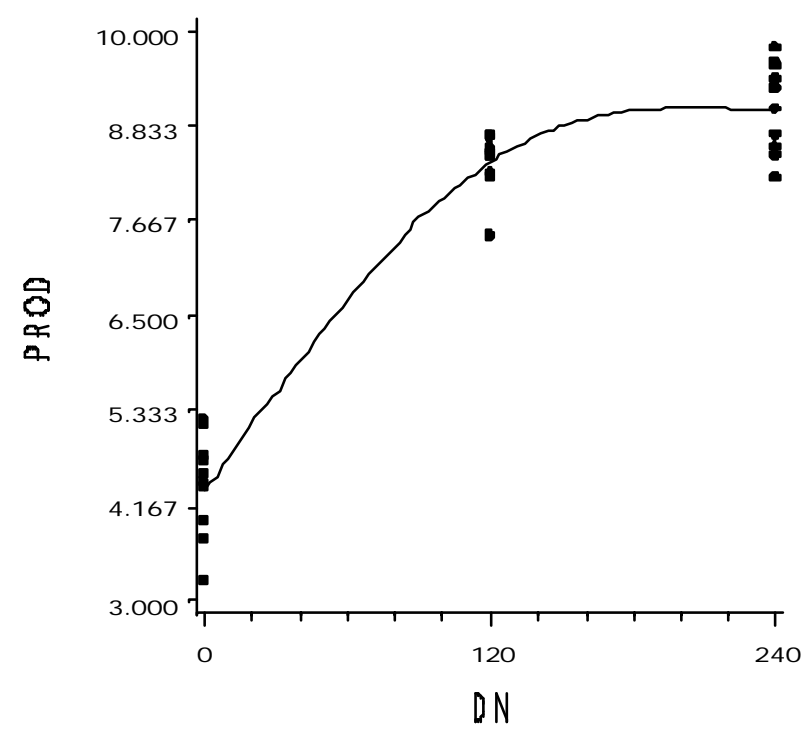

Figura 18 - Produtividade da cultura de milho (PROD, kg.ha ${ }^{-1}$ ) em função de doses de nitrogênio (DN, kg.ha $\left.{ }^{-1}\right)$

Estes resultados foram semelhantes aos obtidos por Coelho (1987), que obtiveram aumento de $80 \%$ na produtividade de grãos ao aplicarem $120 \mathrm{~kg}^{-h a^{-1}}$ de N, e por Ferreira (1997) que observou que a máxima produtividade de grãos da cultura de milho foi atingida mediante a aplicação de $201,2 \mathrm{~kg} \cdot \mathrm{ha}^{-1}$ de N. Também estão de acordo com o exposto por Büll (1993), o qual salienta que, na cultura de milho, os melhores resultados são obtidos com a aplicação $30 \mathrm{~kg} \cdot \mathrm{ha}^{-1}$ de $\mathrm{N}$ na semeadura e $90 \mathrm{~kg} \cdot \mathrm{ha}^{-1}$ de $\mathrm{N}$ em cobertura, totalizando $120 \mathrm{~kg}^{-h a^{-1}}$ de $\mathrm{N}$, normalmente não sendo economicamente viável o uso de doses de $\mathrm{N}$ muito acima desses valores. Tal afirmação foi constatada também por Sangoi \& Almeida (1997) que obtiveram aumento de $67 \%$ na produtividade ao elevarem a dose de $\mathrm{N}$ de $0 \mathrm{~kg} \cdot \mathrm{ha}^{-1}$ para $100 \mathrm{~kg} \cdot \mathrm{ha}^{-1}$, sendo que para doses superiores $\left(150 \mathrm{~kg} \cdot \mathrm{ha}^{-1} \mathrm{de} \mathrm{N}\right)$, o incremento foi de apenas $5 \%$.

É importante salientar que, de acordo com os resultados apresentados na Tabela 14, na qual estão descritos os coeficientes de correlação de Pearson entre as variáveis analisadas, houve alta correlação $(0,9076)$ da variável comprimento de espigas (COMPESP) com a produtividade de grãos (PROD), o que indica ter havido grande 
influência do COMPESP sobre a PROD obtida nos diferentes tratamentos. Esse resultado confirma o citado por Büll (1993), que atribuiu o aumento de produtividade na cultura de milho, proporcionado pelo nitrogênio, aos efeitos positivos do referido elemento sobre o comprimento da espiga. Além do COMPESP, a variável PROD também apresentou alta correlação com as variáveis índice de área foliar determinada aos 65 dias após a emergência das plantas $(0,8607)$, altura de inserção de espigas $(0,8600)$ e altura da base do pendão $(0,8301)$. Tais variáveis estão diretamente relacionadas com a produção (IAF4) e armazenamento (AIE e ABP) de fotoassimilados que são direcionados para os grãos, pois quanto maior a área foliar da planta, maior a capacidade fotossintética da mesma e quanto maior a altura da base do pendão, maior o comprimento do colmo, com conseqüente maior capacidade de armazenamento dos fotoassimilados produzidos.

Ainda, ao analisar os resultados do teste $\mathrm{F}$ (Tabela 13) para a variável produtividade (PROD), verifica-se que a aplicação de doses crescentes de zinco e de boro, no sulco de semeadura da cultura de milho, não alterou significativamente os resultados obtidos, possibilitando concluir que, nas condições em que o experimento foi conduzido, mesmo aplicando doses oito vezes superiores (B até $8 \mathrm{~kg} . h a^{-1}$ e $\mathrm{Zn}$ até 16 $\mathrm{kg} \cdot \mathrm{ha}^{-1}$ ) às comumente recomendadas para a cultura, 1,0 kg.ha ${ }^{-1}$ de B (Yamada \& Lopes, 1998) e $2 \mathrm{~kg} \mathrm{ha}^{-1}$ de $\mathrm{Zn}$ (Melarato, 2000), não houve acréscimo na produtividade e nem prejuízos causados por deficiência ou fitotoxidez.

A ausência de resposta da PROD à aplicação de doses crescentes de zinco pode ser atribuída tanto ao teor do elemento $\left(2,0 \mathrm{mg} \cdot \mathrm{dm}^{-3}\right)$ disponível no solo utilizado para a condução do experimento, o qual pode ser considerado ideal para o desenvolvimento da cultura de milho, de acordo com valores (teores entre 0,5 e $1,0 \mathrm{mg} \cdot \mathrm{kg}^{-1}$ ) citados por Fancelli \& Dourado Neto (2000), como ao fato de que o solo apresenta alto teor de argila, fazendo com que grande parte dos micronutrientes aplicados permanecessem adsorvidos aos colóides e não se tornassem disponíveis em excesso para as plantas. Cabe salientar que de acordo com Lopes (1999), o zinco pode ser fortemente adsorvido pelos colóides do solo, o que pode dificultar a absorção pelas plantas, sendo que, conforme relatado por Rosolem \& Franco (2000), tal adsorção pode ser influenciada por várias 
características do solo como $\mathrm{pH}$, tipo de argila, teor de argila e teor de matéria orgânica. Outro fator que pode ter contribuído para a não obtenção de respostas da PROD à aplicação de doses crescentes de zinco no sulco de semeadura de milho, foi o fato de ter sido utilizado como fonte de zinco, o sulfato de zinco, o qual é muito solúvel (750 g/L a $20^{\circ} \mathrm{C}$, segundo Dourado Neto \& Fancelli, 2001) e pode ter sido lixiviado logo após a aplicação, o que não permitiu a permanência do referido fertilizante em contato com as sementes por muito tempo e nem possibilitou a absorção total pelas plantas das doses aplicadas. É importante ressaltar que os resultados estão de acordo com Souza et al. (1998) que ao avaliarem a resposta da cultura de milho à adição de doses crescentes de zinco no sulco de semeadura, não verificaram sintomas de fitotoxidez ou queda de produtividade de grãos, mesmo quando foram aplicadas doses de $20 \mathrm{~kg}_{\text {.ha }}{ }^{-1}$ de $\mathrm{Zn}$. Os referidos autores, apesar de verificarem respostas da cultura a adiçào de doses crescentes de zinco no sulco de semeadura, não observaram vantagens em aplicar doses superiores a 5 kg.ha ${ }^{-1}$ de Zn. Ferreira (1997), ao estudar a interação entre os elementos nitrogênio e zinco aplicados no sulco de semeadura de milho, também não constataram influência do zinco e de suas interações com o nitrogênio sobre nenhuma das variáveis estudadas, inclusive sobre a produtividade de grãos.

Quanto ao boro, a aplicação deste elemento em doses crescentes no sulco de semeadura também não influenciou significativamente na produtividade, o que pode ser atribuído aos altos teores de argila e de matéria orgânica do solo (alta capacidade de adsorção do elemento) e/ou à alta solubilidade da fonte utilizada (ácido bórico), a qual pode ter sido parcialmente lixiviada antes de ser absorvida totalmente pela cultura. Também pode atribuir-se ao teor do elemento $\left(0,35 \mathrm{mg}^{-\mathrm{dm}^{-3}}\right)$ disponível no solo utilizado para a condução do experimento, o qual pode ser considerado ideal para o desenvolvimento da cultura de milho, de acordo com valores (entre 0,1 e 0,3 mg. $\mathrm{kg}^{-1}$ ) citados por Fancelli \& Dourado Neto (2000). Cabe salientar que os resultados obtidos são semelhantes aos descritos por Büll (1993) que também não observou respostas da cultura de milho à aplicação de boro e cita que, de maneira geral, as respostas da cultura de milho à aplicações de boro não são consistentes. Touchton \& Boswell (1975) e Abreu \& Lopes (1985), também não observaram respostas da cultura 
de milho à aplicação do referido nutriente. É válido destacar ainda que Chapman et al., 1997 e Yamada, 2000, citam que, apesar de haver uma série de trabalhos que previnem a aplicação de maiores doses de boro no solo, que as atualmente praticadas, a faixa entre a deficiência e a fitotoxidez na planta é muito estreita e que ainda não há até o momento evidências que suportem essa idéia. 


\section{CONCLUSÕES}

Em função dos resultados obtidos nas condições do experimento, pode-se concluir que:

i) a aplicação de nitrogênio em doses crescentes proporcionou aumento tanto da produtividade de grãos, como de uma série de outras variáveis que contribuíram para esse aumento como índice de área foliar, número de folhas, altura da base do pendão, altura de inserção da espiga, comprimento do segundo internódio do colmo, diâmetro do colmo, comprimento da espiga, massa de matéria seca da espiga e prolificidade. Para todas essas variáveis os melhores resultados foram proporcionados pela aplicação de 120 kg.ha ${ }^{-1}$ de $\mathrm{N}$, sendo que a aplicação do dobro da dose $\left(240 \mathrm{~kg} \cdot \mathrm{ha}^{-1}\right.$ de $\left.\mathrm{N}\right)$ não resultou em acréscimos significativos nos valores obtidos.

ii) a máxima produtividade de grãos $\left(9182 \mathrm{~kg}_{\mathrm{h}} \mathrm{ha}^{-1}\right)$ foi obtida mediante o uso da dose de 202,6 kg.ha ${ }^{-1}$ de $\mathrm{N}$, sendo esta dose considerada inviável perante ao incremento

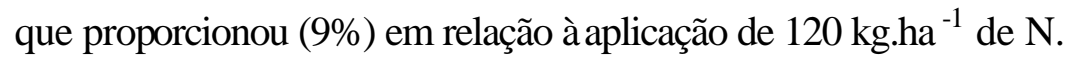

iii) até o momento em que as plantas apresentavam 4 folhas plenamente desdobradas, não haviam sintomas visuais de diferenças entre os tratamentos estudados, o que leva a concluir que somente a partir deste estádio é que as plantas passaram a realmente depender dos nutrientes disponíveis no solo e aumentaram a demanda pelos mesmos (absorção).

iv) nenhum dos nutrientes estudados $(\mathrm{B}, \mathrm{Zn}$ e $\mathrm{N})$ exerceu influência significativa sobre as variáveis número de folhas (NF1) e índice de área foliar (IAF1) aos 20 dias após a emergência, comprimento do primeiro internódio do colmo (COMP_NO1), massa de matéria seca de pendão (MMSP), número de fileira de grãos (NFG) e comprimento dos grãos (COMPGRAO).

v) a aplicação de doses elevadas de zinco (até $16 \mathrm{~kg} \mathrm{ha}^{-1}$ ) e de boro (até 
$8 \mathrm{~kg} \mathrm{ha}^{-1}$ ) no sulco de semeadura não influenciou significativamente os componentes de produção da cultura de milho, o que pode ser atribuído aos altos teores de argila e de matéria orgânica do solo em que conduziu-se o experimento (alta capacidade de adsorção do elemento) e/ou à alta solubilidade das fontes utilizadas (sulfato de zinco e ácido bórico). Por outro lado, a não ocorrência de deficiência dos referidos elementos nos tratamentos em que os mesmos não foram aplicados pode ter sido devido ao fato de que os níveis, tanto de zinco como de boro, no solo, eram satisfatórios para suprir as necessidades da cultura.

vi)apesar de não afetar a produtividade de grãos, a aplicação de doses crescentes de zinco no sulco de semeadura exerceu influência significativa sobre a massa de matéria seca de colmo (MMSC) e de folha (MMSF), sendo que para a MMSC os máximos valores foram atingidos com a aplicação de $8 \mathrm{~kg}_{\mathrm{h}} \mathrm{ha}^{-1}$ de $\mathrm{Zn}$, havendo um decréscimo quando doses maiores $\left(16 \mathrm{kgha}^{-1}\right)$ do elemento foram aplicadas. Quanto à MMSF, verificourse que a aplicação de zinco proporcionou efeito positivo nos resultados, uma vez que quanto maior a dose de $\mathrm{Zn}$ aplicada no sulco de semeadura, maior foi o valor de MMSF obtido, até mesmo para a dose de $16 \mathrm{~kg} \mathrm{ha}^{-1} \mathrm{de} \mathrm{Zn}$.

vii) houve efeito da interação entre os elementos zinco e nitrogênio sobre a variável massa de mil grãos (M1000G) sendo que quanto maior a dose de nitrogênio aplicada, menores foram as respostas da M1000G à aplicação de boro. O mesmo rão aconteceu com a produtividade o que confirma a baixa correlação entre as duas variáveis $(0,5144)$.

viii) a aplicação de boro, associada à aplicação de nitrogênio, influenciou negativamente o índice de área foliar determinado 41 dias após a emergência (IAF2), porém tal efeito desapareceu posteriormente devido, provavelmente, a uma diluição do referido elemento na planta àmedida que a mesma foi aumentando de tamanho.

ix) a aplicação de boro em alta dose $\left(8 \mathrm{~kg} \mathrm{ha}^{-1}\right)$ no sulco de semeadura exerceu influência significativa sobre o número de grãos por fileira da espiga (NGF). Assim como aconteceu para o IAF2, quanto maior a dose de $\mathrm{N}$ aplicada, menores foram os efeitos benéficos do boro sobre o NGF, sendo que altas doses de N (240 kg.ha $\left.{ }^{-1}\right)$ potencializaram os efeitos negativos do excesso de boro aplicado no sulco de semeadura 
sobre o número de grãos por fileira, ou seja, ao aplicar $240 \mathrm{~kg} \cdot \mathrm{ha}^{-1} \mathrm{de} \mathrm{N}$, a aplicação de 8 kg.ha ${ }^{-1}$ de B provocou queda de $19 \%$ no NGF das espigas de milho.

x) Dentre as variáveis analisadas, a que apresentou maior correlação com a produtividade de grãos foi o comprimento de espigas. Houve também alta correlação do número de folhas com o índice de área foliar da cultura. 


\section{REFERÊNCIAS BIBLIOGR ÁFICAS}

ABREU, C.A. Análise de solo para micronutrientes. Tema de reuniões de laboratórios. Informações Agronômicas, n.74, p.9, 1996.

ABREU, C.A.; LOPES, A.S. Identificação de deficiências de micronutrientes em cinco solos de várzeas da região de cerrado de Minas Gerais. In: CONGRESSO BRASILEIRO DE CIÊNCIA DO SOLO, 2., Belém, 1985. Resumos. Campinas: Sociedade Brasileira de Ciência do Solo, 1985. p.76

ANDRADE, F.H.; UHART, S.; ARGUISSAIN, G. Rendimento potencial del maiz en Balcarce: analisis de los fatores que lo determinan. Barcelona: Instituto Nacional de Tecnologia Agropecuária, 1991. 11p. (Boletim Técnico, 101)

ARNON, I. Mineral nutrition maize. Bern: International Potash Institute, 1975. 452p.

BARBOSA FILHO, M.P. Nutrição e adubação do arroz (sequeiro e irrigado). Piracicaba: POTAFOS, 1987. 120p. (Boletim Técnico, 9)

BATAGLIA, O.C.; DECHEN, A.R. Critérios alternativos para diagnose foliar. In: SIMPÓSIO AVANÇADO DE QUÍMICA E FERTILIDADE DO SOLO, 1., Piracicaba, 1986. Anais. Campinas: Fundação Cargill, 1986. p.115-136

BORKERT, C.M. Micronutrientes na planta. In: BÜLL, L.T.; ROSOLEM, C.A. Interpretação de análise química de solo e planta para fins de adubação. Botucatu: Fundação de Estudos e Pesquisas Agrícolas e Florestais, 1989. p.309-329.

BRASIL. Ministério da agricultura e reforma agrária. Regras para análise de sementes. Brasília, 1992. 365p.

BROWN, A.L.; QUICK, J.; EDDINGS, J.L. A comparasion of analytical methods for soil zinc. Soil Science Society of America, v.35, n.1, p.105-107, 1971.

BROWN, P.H.; HU, H. Manejo do boro de acordo com sua mobilidade nas diferentes culturas. Informações Agronômicas, n.84, p.1-4, 1998. 
BÜLL, L.T. Nutrição mineral do milho. In: BÜLL, L.T.; CANTARELLA, H. Cultura do milho: fatores que afetam a produtividade. Piracicaba: POTAFOS, 1993. p.63145.

BUZETTI, S.; MURAOKA, T.; MAURO, A.O. Doses de zinco em diferentes condições de acidez de um solo de cerrado. Pesquisa Agropecuária Brasileira, v.26, n.6, p.913-918, 1991.

CHAPMAN, V.J.; EDWARDS, D.G.; BLAMEY, F.P.C.; ASCHER, C.J. Challenging the dogma of a narrow supply range between deficiency and toxicity of boron. In: BELL, R.W.; RERKASEM, B. Boron in soils and plants. Dordrecht: Kluwer Academic Publishers, 1997. p.151-155.

COBUCCI, T. Efeitos de doses e épocas de aplicação em cobertura do adubo nitrogenado no consórcio milho-feijão. Viçosa, 1991. 94p. Dissertação (Doutorado) - Universidade Federal de Viçosa.

COELHO, A.M. Balanço de nitrogênio (15N) na cultura do milho (Zea mays L.) em um Latossolo Vermelho-escuro fase cerrado. Lavras, 1987. 142p. Tese (Mestrado) - Universidade Federal de Lavras.

COELHO, A.M.; FRANÇA, G.E. Seja doutor do seu milho. Arquivo do Agrônomo, n.2, p.1-24, 1995.

COX, F.R.; KAMPRATH, E.J. Micronutrient soil tests. In: MORTVEDT, J.J.; GIORDANO, P.M.; LINDSAY, W.L. (Ed.). Micronutrients in agriculture. Madison: Soil Science of America, 1972. p.289-317.

DECARO, S.T.; VITTI, G.C.; FORNASIERI FILHO, D.; MELLO, W.J. Efeitos de doses e fontes de zinco na cultura de milho (Zea mays L.). Revista de Agricultura, v.58, n.1/2, p.25-36, 1983.

DECHEN, A.R. Micronutrientes: funções nas plantas. In: SIMPÓSIO SOBRE MICRONUTRIENTES NA AGRICULTURA, Jaboticabal, 1988. UNESP; FCAV, Anais.p.111-132.

DECHEN, A.R.; HAAG, H.P.; CARMELLO, Q.A.C. Funções dos micronutrientes nas plantas. In: FERREIRA, M.E.; CRUZ, M.C.P. Micronutrientes na agricultura. Piracicaba. POTAFOS, 1991. p.65-78. 
DOURADO NETO, D.; FANCELli, A.L. Produção de feijão. Guaíba: Agropecuária, 2000. $385 \mathrm{p}$.

DOURADO NETO, D.; FANCELLI, A.L. Manejo de água na cultura de feijão: aspectos práticos. In: : FANCELLI, A.L.; DOURADO NETO, D. (Ed.). Sistemas de produção de feijão irrigado. Piracicaba: ESALQ, 2001. p.138-156.

FANCELLI, A.L. Plantas alimentícias: guia para aula, estudos e discussão. Piracicaba: CALQ, 1986. 131p.

FANCELLI, A.L.; DOURADO NETO, D. Fenologia do milho. In: FANCELLI, A.L.; DOURADO NETO, D. (Coord.). Tecnologia da produção de milho. Piracicaba: Publique, 1997. p.131-134.

FANCELli, A.L.; DOURADO NETO, D. Produção de milho. Guaíba: Agropecuária, 2000. $360 \mathrm{p}$.

FANCELLI, A.L.; LIMA. U.A. Milho: produção, pré-processamento e transformação agroindustrial.São Paulo: SICCI; PROMOCET; FEALQ, 1982. 112p. (Série Extensão Agroindustrial, 5).

FERREIRA, A.C.B. Efeitos da adubação com N, Mo e Zn sobre a produção, qualidade de grãos e concentração de nutrientes no milho. Viçosa, 1997. 73p. Tese (Mestrado) - Universidade Federal de Viçosa.

FNP CONSULTORIA. AGRIANUAL 2003: anuário da agricultura brasileira. São Paulo, 2002. 544p.

FRANCIS, C.A.; RUTGER, J.N.; PALMER, A.F.E.A. Rapid method for plant leaf area estimation in maize (Zea mays). Crop Science, v.9, p.537-539, 1969.

FURLANI, A.M.C.; FURLANI, P.R. Resposta de cultivares de milho a zinco em solução nutritiva. Bragantia, v.55, n.2, p.365-369, 1996.

GALRÃO, E.Z. Métodos de correção da deficiência de zinco para o cultivo de milho num Latossolo Vermelho-Escuro argiloso sob cerrado. Revista Brasileira de Ciência do Solo, v.18, p.229-33, 1994.

GALRÃO, E.Z. Níveis críticos de zinco para o milho cultivado em Latossolo VermelhoAmarelo, fase cerrado. Revista Brasileira de Ciência do Solo, v.19, p.255-60, 1995. 
GALRÃO, E.Z.; MESQUITA FILHO, M.V. Efeito de fontes de zinco na produção de matéria seca do milho em um solo sob cerrado. Revista Brasileira de Ciência do Solo, v.5, n.3, p.167-70, 1981.

IGUE, K.; GALLO, J.R. Deficiência de zinco em milho mo Estado de São Paulo. São Paulo: IBEC Research Institute, 1960. 19p. (Boletim, 20)

JONES JR, J.B. Plant tissue analysis for micronutrients. In: MORTVEDT, J.J.; GIORDANO, P.M.; LINDSAY, W.L. (Ed.). Micronutrients in agriculture. Madison: Soil Science Society of America, 1972. p.319-346.

LIMA FILHO, O.F. Calibração de boro e zinco para o cafeeiro (Coffea arabica L. cv. Catuaí amarelo). Piracicaba, 1991. 100p. Dissertação (Mestrado) - Centro de Energia Nuclear na Agricultura, Universidade de São Paulo.

LOPES, A.S. Micronutrientes: filosofias de aplicação, fontes, eficiência agronômica e preparo de fertilizantes. In: FERREIRA, M.E.; CRUZ, M.C.P. Micronutrientes na agricultura. Piracicaba: POTAFOS, 1991. p.357-390.

LOPES, A.S. Micronutrientes: filosofia de aplicação e eficiência agronômica. São Paulo: Associação Nacional para Difusão de Adubos, 1999. 70p.

MALAVOLTA, E.; DANTAS, J.P. Nutrição e adubação do milho. In: PATERNIANI, E.; VIEGAS, G.P. Melhoramento e produção do milho. 2.ed. Campinas: Fundação Cargill, 1987, v.2, p.541-593.

MALAVOLTA, E.; BOARETTO, A.E.; PAULINO, V.T. Micronutrientes: uma visão geral. In: FERREIRA, M.E.; CRUZ, M.C.P. Micronutrientes na agricultura. Piracicaba: POTAFOS, 1991. p.1-34.

MALAVOLTA, E.; VITTI, G.C.; OLIVEIRA, S.A. Avaliação do estado nutricional das plantas: princípios e aplicações. Piracicaba: POTAFOS, 1989. 201p.

MALAVOLTA, E.; VITTI, G.C.; OLIVEIRA, S.A. Avaliação do estado nutricional das plantas: princípios e aplicações. 2.ed. Piracicaba: POTAFOS, 1997. 319p.

MALAVOLTA, E.; PAULINO, V.T.; LOURENÇO, A.J.; MALAVOLTA, M.L.; ALCARDE, J.C.; CORRÊA, J.C.; TERRA, M.M.; CABRAL, C.P. Eficiência relativa de fontes de zinco para o milho (Zea mays L.). Anais da Escola Superior de Agricultura 'Luiz de Queiroz”, v.44, n.1, p.57-76, 1987. 
MARCOS FILHO, J. Fenologia de grandes culturas: apontamentos para aula. Piracicaba: Departamento de Agricultura, ESALQ, 1997. 36p.

MELARATO, M. Micronutrientes no sistema plantio direto. In: SIMPÓSIO SOBRE FERTILIDADE DO SOLO E NUTRIÇÃO DE PLANTAS NO SISTEMA PLANTIO DIRETO, 1., Ponta Grossa, 2000. Ponta Grossa: Associação de Engenheiros Agrônomos dos Campos Gerais, 2000. p.161-174.

MENGEL, K.; KIRKBY, E.A. Principles of plant nutrition. Bern: International Potash Institute, 1987. 667p.

MOZAFAR, A. Effect of boron on ear formation and yield components of two maize (Zea mays L.) hybrids. Journal of Plant Nutrition, v.10, n.3, p.319-32, 1987.

NOGUEIRA-JÚNIOR., S.; NOGUEIRA, E. A.; TSUNECHIRO, A. Considerações sobre a agroindústria do milho. São Paulo: Instituto de Economia Agrícola, 1987. 18p. (IEA Relatório de Pesquisa, 27).

OLIVEIRA, E.F. de. Eficiência do modo de aplicação do sulfato de amônio e uréia nas culturas de milho e algodão. In: ORGANIZAÇÃO DAS COOPERATIVAS DO ESTADO DO PARANÁ. Resultados de pesquisa 1/95. Cascavel, 1995. p.40-46.

PAVAN, M.A.; CORREA, A.E. Reações de equilíbrio solo-boro. Pesquisa Agropecuária Brasileira, v.23, n.3, p.261-269, 1988.

PECK, T.R.; WALKER, W.M.; BOONE, L.V. Relationship between corn (Zea mays L.) yield and leaf levels of ten elements. Agronomy Journal, v.61, n.2, p.299-301, 1969.

QUAGGIO, J.A. Acidez e calagem em solos tropicais. Campinas: Instituto Agronômico de Campinas, 2000. 111p.

RAIJ, B. van. Fertilidade do solo e adubação. São Paulo: Agronômica Ceres, 1991a. $343 p$.

RAIJ, B. van. Geoquímica de micronutrientes. In: FERREIRA, M.E.; CRUZ, M.C.P. Micronutrientes na agricultura. Piracicaba: POTAFOS, 1991b. p.99-112. 
RAIJ, B. van; FEITOSA, C.T.; CANTARELlA, H.; CAMARGO, A.P.; DECHEN, A.R.; ALVES, S.; SORDI, G.; VEIGA, A.A.; CAMPANA, M.P.; PETINELLI, A.; NERY, C. A análise de solo para discriminar respostas à adubação para a cultura do milho. Bragantia, v.40, p.57-75, 1981.

RAIJ, B. van; SILVA, N.M. da; BATAGLIA, O.C.; QUAGGIO, J.A.; HIROCE, R.; CANTARELlA, H.; BELLINAZZI JUNIOR, R.; DECHEN, A.R.; TRANI, P.E. Recomendações de adubação e calagem para o Estado de São Paulo. Campinas: Instituto Agronômico, 1985. 107p. (IAC. Boletim Técnico, 100).

RIBEIRO, A.C.; BRAGA, J.M. Adsorção de boro pelo solo. Experientiae, v.17, p.293310, 1974.

ROSOLEM, C.A.; FRANCO, G.R. Translocação de zinco e crescimento radicular em milho. Revista Brasileira de Ciência do Solo, v.24, p.807-814, 2000.

SÁ, J.C.M. Efeito de doses e época de aplicação de nitrogênio na produção de milho, após resteva de aveia preta (Avena strigosa), sob plantio direto. In: FUNDAÇÃO ABC. Resultados de pesquisa 88/89. Ponta Grossa, 1989. (Boletim Técnico, 4).

SAS. SAS/STAT ${ }^{\circledR}$ users guide, version 6.12. Cary: Statistical Analysis System Institute Incorporation, 1998.

SANGOI, L.; ALMEIDA, M.L. Doses e épocas de aplicação de nitrogênio para a cultura de milho num solo com alto teor de matéria orgânica. Pesquisa Agropecuária Brasileira, v.29, n.1, p.13-24, 1994.

SILVA, H.P.; MENTEN J.O.M. Manejo integrado de doenças na cultura do milho In: FANCELLI, A.L.; DOURADO NETO D. (Coord.). Tecnologia da produção de milho. Piracicaba: Publique, 1997. p.40-56.

SOUZA, E.C.A.; COUTINHO, E.L.M.; NATALE, W.; BARBOSA, J.C. Respostas do milho à adubação com fósforo e zinco. Pesquisa Agropecuária Brasileira, v.33, n.7, p.1031-1036, 1998.

SOUZA, E.C.A.; SANTIAGO, G.; OLIVEIRA, L.C.L.; COUTINHO, E.L.M.; LIMA, L.A. Respostas do milho à adubação com fósforo e zinco. Científica, v.13, p.39-49, 1985.

TOUCHTON, J.T.; BOSWELL, F.C. Boron application for corn grown on selected 
southeastern soils. Agronomy Journal, v.67, n.2, p.197-200, 1975.

WOODRUFF, J.R.; MOORE, F.W.; MUSEN, H.L. Potassium, boron, nitrogen, and lime effects on corn yield and ear leaf nutrient concentrations. Agronomy Journal, v.79, n.3, p.520-524, 1987.

YAMADA, T. Adubação nitrogenada do milho. Quanto, como e quando aplicar? Informações Agronômicas, n.74, p.1-5, 1996.

YAMADA, T. Boro: será que estamos aplicando a dose suficiente para o adequado desenvolvimento das plantas? Informações Agronômicas, n.90, p.1-5, 2000.

YAMADA, T.; LOPES, A.S. Balanço de nutrientes na agricultura brasileira. Informações Agronômicas, n.84, p.1-8, 1998.

ZUBLENA, J.P.; ANDERSON, J.R. Soil facts: Starter fertilizers for corn production. North Carolina Cooperative Extension Service, 1994. 8p. 